Review

\title{
Circadian Rhythms of the Hypothalamus: From Function to Physiology
}

\author{
Rachel Van Drunen ${ }^{1,2}$ and Kristin Eckel-Mahan 1,2,* \\ 1 MD Anderson UTHealth School Graduate School of Biomedical Sciences, Houston TX 77030, USA; \\ Rachel.VanDrunen@uth.tmc.edu \\ 2 Brown Foundation Institute of Molecular Medicine University of Texas McGovern Medical School, \\ Houston, TX 77030, USA \\ * Correspondence: Kristin.L.Mahan@uth.tmc.edu
}

Citation: Van Drunen, R.; Eckel-Mahan, K. Circadian Rhythms of the Hypothalamus: From Function to Physiology. Clocksesleep 2021, 3, 189-226. https://doi.org/10.3390/ clockssleep3010012

Academic Editor: Hiroshi Kadotani

Received: 5 January 2021

Accepted: 18 February 2021

Published: 25 February 2021

Publisher's Note: MDPI stays neutral with regard to jurisdictional claims in published maps and institutional affiliations.

Copyright: (c) 2021 by the authors. Licensee MDPI, Basel, Switzerland. This article is an open access article distributed under the terms and conditions of the Creative Commons Attribution (CC BY) license (https:// creativecommons.org/licenses/by/ $4.0 /)$.

\begin{abstract}
The nearly ubiquitous expression of endogenous $24 \mathrm{~h}$ oscillations known as circadian rhythms regulate the timing of physiological functions in the body. These intrinsic rhythms are sensitive to external cues, known as zeitgebers, which entrain the internal biological processes to the daily environmental changes in light, temperature, and food availability. Light directly entrains the master clock, the suprachiasmatic nucleus (SCN) which lies in the hypothalamus of the brain and is responsible for synchronizing internal rhythms. However, recent evidence underscores the importance of other hypothalamic nuclei in regulating several essential rhythmic biological functions. These extra-SCN hypothalamic nuclei also express circadian rhythms, suggesting distinct regions that oscillate either semi-autonomously or independent of SCN innervation. Concurrently, the extra-SCN hypothalamic nuclei are also sensitized to fluctuations in nutrient and hormonal signals. Thus, food intake acts as another powerful entrainer for the hypothalamic oscillators' mediation of energy homeostasis. Ablation studies and genetic mouse models with perturbed extra-SCN hypothalamic nuclei function reveal their critical downstream involvement in an array of functions including metabolism, thermogenesis, food consumption, thirst, mood and sleep. Large epidemiological studies of individuals whose internal circadian cycle is chronically disrupted reveal that disruption of our internal clock is associated with an increased risk of obesity and several neurological diseases and disorders. In this review, we discuss the profound role of the extra-SCN hypothalamic nuclei in rhythmically regulating and coordinating body wide functions.
\end{abstract}

Keywords: circadian rhythm; clock genes; hypothalamus; extra-SCN hypothalamic nuclei; metabolism; food-entrainable oscillator; obesity

\section{Introduction}

Most organisms on earth exhibit highly conserved $24 \mathrm{~h}$ rhythms in physiology and behavior. Constant $24 \mathrm{~h}$ rotations of the earth punctuated by the rising and setting of the sun contribute to an organism's circadian (i.e., $24 \mathrm{~h}$ ) biology at the molecular, cellular, and behavioral levels. This internal clock not only sensitizes, but enables an organism to anticipate daily fluctuations in its environment. This time-keeping process operates in almost all cells of an organism and is self-perpetuating, even in the absence of external cues [1]. Although circadian clocks throughout the body are synchronized in large part through the suprachiasmatic nucleus (SCN) of the hypothalamus, rhythmicity in other hypothalamic nuclei has proved to be a critical regulator of physiological rhythms such as the sleep-wake cycle and daily food intake.

The circadian clock in the hypothalamus and elsewhere ultimately depends on $24 \mathrm{~h}$ rhythms at the cellular level, where a central transcription-translation feedback loop (TTFL) regulates the expression of key clock transcription factors (TFs). The core loop is a heterodimer consisting of circadian locomotor output cycles kaput (CLOCK) and brain and muscle ARNT-like protein (BMAL1), which promote the rhythmic expression of numerous 
E-Box-containing output genes, including the Period (Per 1-3) and Cryptochrome (Cry $1-2)$ genes, which as proteins function as direct repressors of the CLOCK:BMAL1 heterodimer [1,2]. Resumption of CLOCK:BMAL1 activity occurs only when these repressors

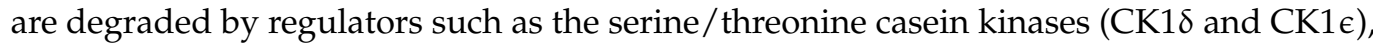
which phosphorylate PER, initiating its ubiquitination. CRY turnover is also controlled by phosphorylation; the metabolic sensor $5^{\prime}$ adenosine monophosphate-activated protein kinase (AMPK) tags it for proteasome degradation by direct phosphorylation. Additional loops consisting of the nuclear receptor subfamily $1 \mathrm{D}$ member 1 (NR1D1) also known as REV-ER $\alpha / \beta$ and the retinoic acid receptor-related orphan receptors (RORs) sustain this core transcriptional loop by transactivating or repressing Bmal1 [3-5]. An integral non-circadian loop intertwined with the core clock includes the circadian metabolite nicotinamide adenine dinucleotide $\left(\mathrm{NAD}^{+}\right)$. The $\mathrm{NAD}^{+}$-dependent deacetylase sirtuin 1 (SIRT1) directly binds to the CLOCK:BMAL1 heterodimer, and thereby regulates the NAD ${ }^{+}$salvage pathway transcriptionally [6]. Together, these feedback loops mediate rhythmic expression of hundreds of clock-controlled genes (Figure 1). Importantly, Bmal1 is the only gene in which single-gene knockout results in full loss of rhythmicity at the cellular and behavioral levels in a normal light-dark cycle [7,8], though double knockouts of Cry1 and Cry2 can result in complete arrhythmicity in constant darkness $[9,10]$. This underscores the robust and resilient, though highly intricate, nature of our internal clocks to maintaining time.

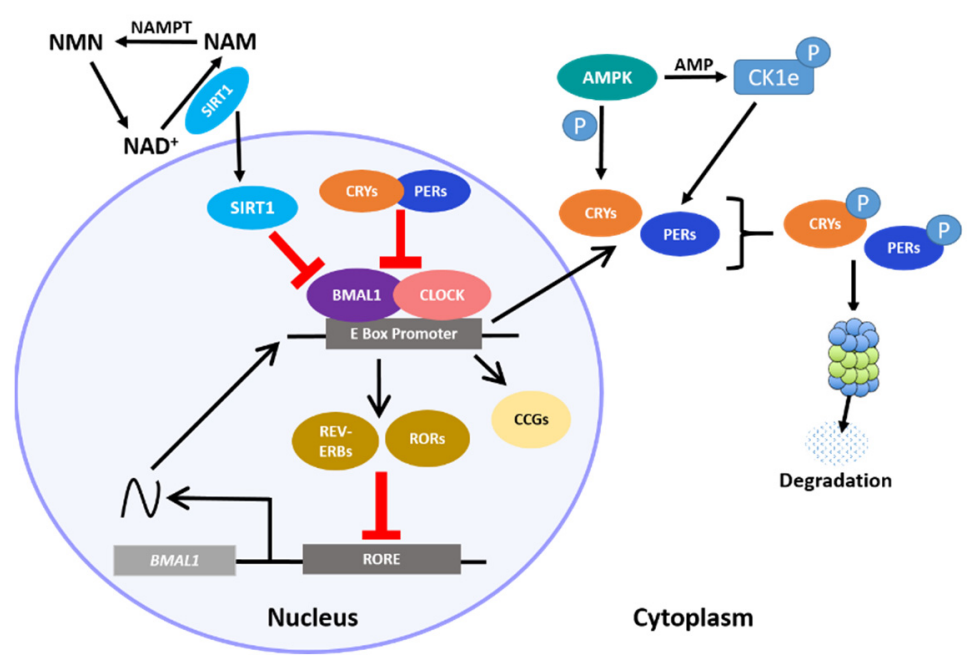

Figure 1. Interactions between the core clock and intracellular metabolism. The heterodimerization of BMAL1 and CLOCK proteins and subsequent binding to E-Box-containing regulatory elements leads to expression of the repressor PER and CRY proteins, the REV-ERBs and RORs, which initiate the auxiliary loop, and the core clock genes (CCGs) that drive numerous other intracellular rhythms. Cytoplasmic PER and CRY proteins are eventually tagged for degradation by AMPK. Rhythmic cellular metabolism, such as rhythmic $\mathrm{NAD}^{+}$abundance, participates in the core clock by direct regulation of clock-associated factors, such as the anti-aging-associated histone deacetylase protein, SIRT1.

Numerous epidemiological studies have shed light on the importance of rhythmicity on health. Over time, disruption of our $24 \mathrm{~h}$ cycle can lead to deleterious physiological outcomes, such as premature aging, and an increased risk for several diseases and disorders including obesity, cardiovascular disease, Alzheimer's disease and other neurological diseases [11-17]. Epidemiological studies on night shift workers have revealed a type of desynchrony or "misalignment" of biological processes in individuals under shift work [18]. The circadian mechanisms driving daytime wakefulness find themselves in conflict with the homeostatic drive for sleep that accumulates as daytime progresses, leading to circadian perturbation [19-21]. Shift work and jet lag are not the only forms of circadian disruption; nutrient stress (a prominent disruptor of peripheral rhythms [22]), nocturnal light pollution, 
and mistimed food intake are additional examples of potent zeitgebers (or "time-givers") that alter the internal biological clock and its synchrony across tissues [23,24].

Photic stimulation is the most powerful zeitgeber for the brain's clock. Light is directly received by retinal ganglion cells (ipRGCs), which contain the photopigment melanopsin. The ipRGCs depolarize independently from the rods and cones to relay light information to the SCN, a small region of the anterior hypothalamus with critical synchronizing capabilities. A combination of ablation studies in rats and monkeys, along with clinical psychiatric observations carried out in the mid-1900s first implicated a circadian clock in the hypothalamic region [25,26]. However, it was not until the discovery of the retinohypothalamic tract (RHT) in rats that the SCN was proven to be important for rhythmicity [27]. The SCN was identified in 1972 by two groups, who showed that electrolytic lesion of the SCN in rats resulted in the loss of locomotor and drinking rhythmicity $[28,29]$. Electrophysiological studies in rats demonstrated that SCN rhythmicity could be maintained for days in vitro following ex-plantation from the surrounding brain tissue [30]. Later studies also revealed that arrhythmicity in hamsters with $\mathrm{SCN}$ lesions could be restored when a fetal SCN was grafted onto the lesioned SCN in vivo [31]. Together, these studies underscore the robustness of the SCN and its requirement for circadian rhythms and behavior (reviewed in Herzog et al. 2017 [32]). The SCN coordinates the entire mammalian circadian system, through the complex regulation of electrical and hormonal signals that propagate throughout the brain and the periphery [33]. Though initially thought to be the dominant component of the $24 \mathrm{~h}$ biological clock in the mammalian system, genetic editing tools have revealed new roles of the circadian clock throughout various tissues of the body, where it controls processes as disparate as glucose sensitization, fluid balance, immune defense, lipid metabolism, and cell migration, among many others [34-41]. Moreover, when explanted from the body into culture, these tissue clocks maintain rhythms, indicating their own autonomy [42].

\section{Chronology of Clocks in the Hypothalamic Nuclei}

Hypothalamic extra-SCN oscillators are now recognized to play integral roles in essential physiological functions such as eating, sleep-wake cycles, energy metabolism and thermoregulation [43-46]. One example of diurnal activity considered to be controlled independently of the $\mathrm{SCN}$ is food-anticipatory activity (FAA), which can persist in spite of SCN ablation [47]. As the name suggests, FAA involves increased activity in anticipation of an upcoming meal, which is particularly evident when daily feeding is restricted to a temporally restrictive time window. Rats express FAA in constant darkness (or "freerunning" conditions) and even in the absence of a functional SCN [47]. These findings point to an elusive food-entrainable circadian oscillator (FEO) which is independent of the SCN [48].

To date, how these extra-SCN oscillators function relative to or in coordination with the SCN is still under investigation. The SCN has direct projections to various hypothalamic regions as well as non-hypothalamic regions such as the periventricular nucleus of the thalamus, the intergeniculate leaflet, the lateral septum and the periaqueductal gray [49]. However, the SCN predominantly innervates hypothalamic nuclei where dense projections to the subparaventricular zone (SPVZ) and the medial preoptic area (MPOA) have been observed [50-52]. Neural tracing studies have revealed that the dorsal medial hypothalamus (DMH), arcuate nucleus (ARC), lateral hypothalamus (LH), paraventricular nucleus (PVN), ventral lateral hypothalamus $(\mathrm{VMH})$, and the ventral lateral preoptic area (VLPO) are also targets of SCN projections $[50,53]$ (Figure 2). Collectively, the ARC, VMH, LH and PVN are heavily involved with hunger and satiety as well as metabolic balance [54-63]. Moreover, neurons in the PVN are also responsible for endocrine regulation through hormone production and release [64,65]. The LH, MPOA, VLPO, DMH and SPVZ regulate sleep/wakefulness, locomotion, and thermoregulation [63,66-69]. Altogether, these hypothalamic nuclei maintain organism-wide energy balance. 


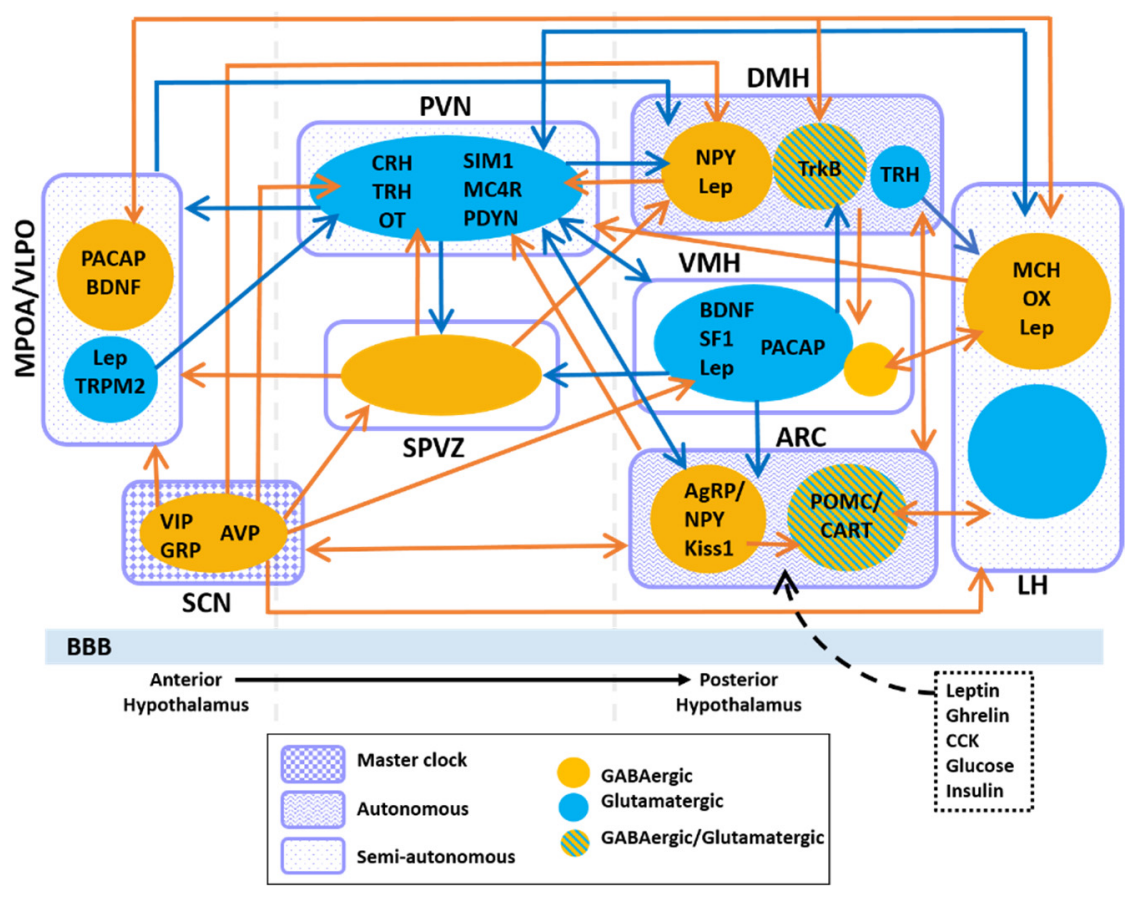

Figure 2. A circuit of hypothalamic oscillators. Numerous afferent and efferent projections characterize the hypothalamic landscape. The "master clock", or the SCN, projects to the major hypothalamic nuclei while only a few nuclei project back to the SCN. Some regions, such as the DMH and ARC host an autonomous clock while other regions such as the PVN, LH and MPOA/VLPO are more heavily dependent on rhythmic innervations. Clock autonomy for the VMH and SPVZ has not been shown. An array of neural subpopulations in the hypothalamus are sensitive to hormones such as leptin, ghrelin, cholecystokinin (CCK), glucose and insulin, which cross the blood-brain barrier (BBB). These hypothalamic nuclei are often characterized by their inhibitory glutamatergic (blue), or their excitatory GABAergic (orange) projections. The gray dotted vertical lines denote the different regions of the hypothalamus. The general flow of information progresses from anterior to posterior, as indicated by the black arrow. Gastrin-Releasing Peptide; TRH = tyrosine hydroxylase; TRPM2 = transient receptor potential cation channel, subfamily $\mathrm{M}$, member 2; VIP = vasoactive intestinal peptide.

Several years following the discovery of non-SCN-driven circadian rhythms of melatonin release by the retina [70], 27 brain regions were examined for rhythmicity independent of the SCN [71]. Utilizing genetically modified rats harboring a Period1 promoter-driven luciferase (Per1-luc) transgene, real-time bioluminescent recordings of isolated brain tissues cultured in vitro [71] revealed that 14 out of the 27 hypothalamic regions examined were able to maintain autonomous rhythms in Per1-luc expression [71]. The most robust rhythms were found in the olfactory bulb, the ARC, the pituitary gland and the PVN [71]. Though the SCN is able to maintain rhythmicity over very long periods of time in vitro, non-SCN tissue rhythms dampened much more quickly. This is thought to be due to the loss of synchronization provided by the SCN between individual cells of other hypothalamic nuclei [42]. Nevertheless, these data suggested a role for semi-autonomous extra-SCN oscillators not only in the hypothalamus, but other regions of the central nervous system (CNS) as well.

\section{A Regulatory Role for Hypothalamic Clocks in Feeding and Food-Anticipatory Activity}

A "feeding center" in the mammalian hypothalamus was described almost 70 years ago, based on the variations in food intake upon injury to certain parts of the hypothalamus [72]. Although FAA was described much earlier than this [73], the presence of anticipatory activity leading up to feeding has been reported in a variety of animals including, bees, fish, marsupials, rabbits, weasels and squirrel monkeys [48,74,75]. Meyer- 
Lohmann conducted a study in 1955 which suggested for the first time that FAA was in fact entrained by a different clock than the one governing locomotor activity. Using mice kept in constant darkness and fed once a day, FAA was maintained at a constant $24 \mathrm{~h}$ rate, with free-running activity rhythms shorter than the typical $24 \mathrm{~h}$ period [76]. This FAA behavior suggested that two different oscillators were functioning to control different behaviors [76]. Additional evidence provided in 1977 showed that periodic food presentation during the rest phase was actually a stronger entrainer than light in driving rhythmic circadian activity [77]. Collectively, these early findings gave birth to the idea of a "feeding center", capable of predicting mealtime and highly circadian in nature, through which energy intake could act as a powerful entrainer of the internal biological clock.

The mechanisms and circuits governing feeding are complex, and identifying a precise area for feeding entrainment has been challenging for the field. The activity shift that occurs in response to a narrow time window of food availability usually involves a $2-3 \mathrm{~h}$ surge of locomotor activity in advance of food availability, and a phase advance in the release of melatonin and arginine vasopressin (AVP) expression in the SCN [78]. A number of different mouse models have been generated to study the role of the tissue-specific CCGs potentially responsible for FAA. Using the Calcium/Calmodulin-Dependent Protein Kinase II Alpha (Camk2a) driver to generate a forebrain deletion of BMAL1 (BKO) in mice resulted in a 90\% reduction of Bmal1 expression in the forebrain region as well as the hypothalamus and the SCN [79]. In this context, weakened rhythms remained in the SCN and the DMH, likely due to remaining rhythmicity in glial cells and unfloxed neurons expressing Bmal1. BKO mice showed blunted feeding rhythms and lacked diurnal activity rhythms. Moreover, in constant darkness, the rhythms of the peripheral tissues became desynchronized and dampened. Under restricted feeding (RF), the BKO mice appear to express FAA, while rhythms in the liver and kidney are restored [79]. This BKO model indicates that the FEO can function independent of synchronization in the forebrain. However, using the Nestin promoter (Nes-Cre), which is specific to the CNS, Mieda and Sakurai 2011 created Bmalffffl ; Nes-Cre $\left(\mathrm{N}-B m a l 1^{-/-}\right)$mice which lack BMAL1 throughout the entire nervous system. These $\mathrm{N}-\mathrm{Bmal1}^{-/}$mice were not behaviorally arrhythmic under constant darkness. However, they were unable to entrain to a RF schedule suggesting that the CNS is still an integral site for the FEO [80]. To specifically examine the role of BMAL1 in extra-SCN hypothalamic regions, the NK2 homeobox 1 driver was used to create $N k \times 2.1-B_{m a l 1}{ }^{-/}$mice. $N k \times 2.1$ is a developmental regulatory gene expressed in the posteroventral hypothalamus yet absent in the adjacent domain where the SCN and its neighboring structures develop $[81,82]$. As a result, the $N k \times 2.1-B m a l 1^{-/-}$mice are devoid of Bmal1 expression in the preoptic area, the nucleus of the diagonal band, and the majority of the hypothalamus, while Bmal1 expression is maintained in the SCN [83]. These Nkx2.1Bmal1 ${ }^{-I-}$ mice showed a shifted pattern of night time behavior, with more activity in the second half of the night compared to controls [83]. Though the overall circadian phenotype of these animals was relatively minor, there was a slight increase in rest phase energy intake in Nkx2.1-Bmal1 ${ }^{-/-}$mice compared to littermate controls. Genetically modified mice lacking Rev-erbo in Nestin-positive cells of the brain showed more remarkable defects in FAA, with a $6 \mathrm{~h}$ RF paradigm resulting in almost no FAA in Rev-erb $\alpha$-deficient mice [84]. The findings support the circadian gene Rev-erb $\alpha$ as important for neuronal prediction of food availability. Additional studies also highlight Rev-erb $\alpha^{\prime}$ s involvement in various metabolic processes including gluconeogenesis and adipocyte differentiation, noting the gene as a regulator of circadian behavior and metabolism [85]. Moreover, a study by Mang et al. 2016 revealed that Rev-erb $\alpha$ knockout mice display an altered sleep homeostasis phenotype, characterized in part by advanced wakefulness relative to the onset of the dark (active) phase, as well as poor adaptability to sleep deprivation [86]. Thus, the altered sleep patterns and inflexibility of the Rev-erb $\alpha$ knockout mice may contribute to the notable defects in FAA [86]. Another knockout study targeting the CLOCK paralog, neuronal PAS domain protein 2 (NPAS2), also found that the NPAS2-KO mice displayed altered sleep homeostasis and took substantially longer than their WT littermates to adapt to a 
RF schedule [87]. While suggestive of circadian genes responsible for FAA, the precise circuits responsible for FAA and the anatomical location of the FEO are still unknown. However, FAA has been shown to induce expression of c-Fos, a marker of neuronal activity, in hypothalamic regions including the ARC, SCN, DMH, PVN, LH and VMH in a manner which follows the degree of caloric restriction. This suggests that one or more of these regions may function together as the FEO and rhythmically modulate feeding [88].

\subsection{Feeding and the Circadian Clock in Neuronal Subtypes of the ARC}

Hypothalamic regulation of feeding begins with the ARC. Positioned lateral to the third ventricle, the ARC forms a complex with the median eminence that is unguarded by the blood-brain barrier (BBB). This unique positioning allows the ARC to sense metabolite, nutrient, lipid and hormone fluctuations in the bloodstream. From this vantage point, the ARC is highly attuned to metabolic and hunger signals to stimulate its first order neuronal subtypes, either the appetite inhibiting pro-opiomelanocortin (POMC)/cocaine amphetamine-regulated transcript (CART) neurons, or the appetite-inducing neuropeptide $\mathrm{Y}(\mathrm{NPY})$ /agouti-related protein (AgRP) neurons which function antagonistically to each other. Though the ARC in mice loses the rhythmic expression of clock and GABAergicrelated genes when the timing of feeding is restricted to the rest period [89], the ARC still maintains a weak but rhythmic dopamine release when the SCN clock is disrupted [90]. In fact, PER2::LUC recordings reveal endogenous circadian rhythms in an explanted ARC, which can be sustained up to eight days, with higher amplitude peaks in the dorsal ARC versus the lateral ARC [91]. Thus, the ARC appears to have its own autonomous clock. Moreover, it is clear that the intrinsic ARC clock is used to mediate the timing and quantity of food intake. Mice placed on RF display rhythmic changes in AgRP/NPY neuronal activity [92]. When the function of AgRP neurons is ablated in neonatal mice, there is diminished FAA, suggesting that AgRP neurons are involved in FAA [92]. Cre-mediated deletion of Bmal1 expression in AgRP neurons (ABKO) in adult mice results in increased feeding, daytime hepatic gluconeogenesis, and respiratory exchange ratio in the ABKO mice, although it is unknown whether these mice express FAA [93]. Lesioning of NPY-ARC neurons causes the uncoupling of feeding from sleep-wake cycles in rats; however, it does not result in loss of food predictability under RF [94]. Similarly, using saportoxin conjugated to leptin to eliminate ARC leptin neurons disrupts the rhythmic integration of activity and body temperature while leaving FAA unaltered in rats [95]. These studies indicate that the FEO is not solely dependent on the ARC.

Using transcriptomics to analyze appetite-regulating pathways in AgRP and POMC neurons of the hypothalamus has revealed an enrichment of circadian signaling factors during food deprivation [96]. Other studies have also revealed changes in the oscillation patterns of clock genes in ARC neurons in response to meal timing [97]. In addition, the neurons of the melanocortin system, predominately localized to the ARC, are well-established contributors to the hypothalamic regulation of metabolism and potential regulators of glucose homeostasis [98].

There are a few crucial molecular signals and receptors in the ARC that are essential to mediating feeding and appear to be involved in FAA. A recent study identified a circadian role for the neurotrophin receptor p75NTR activity in AgRP neurons in driving FAA [99]. p75NTR is a brain-derived neurotrophic-factor (BDNF) receptor that rhythmically mediates oscillation of certain metabolic liver genes [100]. Mice lacking p75NTR in either the AgRP neurons or the entire brain express FAA only during the active phase, but not the rest phase [99]. Additionally, the mammalian target of rapamycin (mTOR) protein, highly expressed in the ARC and PVN, is implicated in rhythmic feeding [101,102]. mTOR is a nutrient-activated serine-theronine kinase which regulates cell growth and metabolism. Activation of hypothalamic mTOR signaling in mice results in anorexia and substantial weight loss [102]. Interestingly, the knockout of mTOR complex 1 (mTORC1) dampens the rhythmic expression of AgRP and NPY, but is negligible for the regulation of feeding and energy homeostasis [103]. However, in POMC neurons, the mTORC1 signaling pathway 
is necessary to carry out leptin-mediated suppression of food intake [104]. Together, these findings suggest that molecular signals within the ARC mediate the timing of food consumption, but may also potentially function as part of the FEO.

\subsection{Feeding and the Circadian Clock in Neuronal Subtypes of the LH, PVN, DMH and VMH}

The function of the LH is best summed by the question "to rest or ingest?" The LH tightly controls energy expenditure and food intake to maintain energy homeostasis [105]. In particular, the abundant orexin (OX) neurons of the LH are crucial for feeding and wakefulness and are sensitized to promote arousal, feeding, locomotion and drinking in the face of energy deficits [106-108]. Widespread projections to the autonomic nervous system (ANS) and the SCN as well as interactions with the neuroendocrine system makes the LH an ideal candidate for involvement in FAA and the FEO. In a RF experiment with a two-hour feeding window, lesions of the LH attenuated FAA behavior as measured by locomotion; however, LH-lesioned rats still show some FAA [109]. However, mice under RF show increased activity of OX-LH neurons in anticipation of feeding [110], suggesting some contribution of the LH in FAA.

Relatively recent research has begun to more thoroughly examine the PVN from a circadian perspective. Inhibitory GABAergic projections from the ARC innervate the $\mathrm{PVN}$, a hypothalamic nuclei that functions as an integrator of metabolic, neuroendocrine, and satiety signals with direct inputs to the ANS. Owing to its diverse functions, the PVN contains a variety of neural subtypes which both receive and send out projections from neighboring hypothalamic nuclei including the DMH, VMH, LH, SCN, MOPA, and SPVZ [111,112]. Ablation of single-minded homolog 1 (SIM1)-positive neurons, a marker of PVN neurons, leads to hyperphagia (over-eating) and obesity [113]. Abe et al. 2002 demonstrated that the PVN maintains 92\% rhythmicity following excision from brain tissue suggesting that a semi-autonomous clock is present [71]. However, other studies centered on the examination of SCN grafts reveal that the PVN is still heavily dependent on the SCN for rhythmic activity [114]. A prime example of this includes a recent optogenetic study, which identifies a SCN-PVN-LH neurocircuit involved in the regulation of wakefulness [115]. These data suggest that the cortisol-releasing hormone (CRH) neurons in the PVN may act as a "pulse generator", whose excitability is regulated by SCN innervations [115].

To determine a potential role for the PVN in FAA, mice with PVN lesions were tested for FAA activity $[109,116,117]$. In spite of its known role in energy intake, lesion of the PVN did not disrupt FAA [118]. In spite of these findings the PVN still presents an attractive possibility for being part of the FEO. For example, oxytocin (OT) has recently been postulated as the main hormonal cue for FAA due to findings linking food entrainment in rabbits to OT-PVN neurons [119]. Although the SCN has direct projections to the PVN, the $\mathrm{PVN}$ neuroendocrine neurons are also indirectly modulated by the $\mathrm{SCN}$ via its innervation of the DMH, ARC and MPOA [120,121].

SIM1-PVN neurons can be divided into two satiety-sensitive subtypes, melanocortin receptor 4 (MC4R) and prodynorphin (PDYN) neurons [122]. Ablation of these neuronal subtypes leads to hyperphagia, obesity, and reduced energy expenditure $[123,124]$. PVN neurons act as secondary order neurons receiving direct projections from the primary order neurons of the ARC. Therefore, ARC-PVN projections are vital to regulating food intake. Rats under a narrow four-hour daily RF window showed elevated NPY levels in the PVN prior to feeding time [125]. ARC-mediated NPY release in the PVN is therefore likely an important orexigenic signal for FAA. From another perspective, the SCN's projections to the PVN are also important to feeding through a light-coupled pathway. During the daytime, light exposure suppresses food intake and increases cFos expression in AVPSCN neurons and OT-PVN neurons in mice [126]. Retrograde tracing has revealed that AVP-SCN neurons terminate on OT-PVN neurons, while blocking OT neurons eliminates the light induced suppression of food intake [126]. These findings highlight a potential neurocircuit explaining light induced suppression of food intake. 
One of the main initial contenders for the FEO was the DMH [127]. Gooley et al. 2006 reported that DMH lesions in rats resulted in loss of FAA as well as disrupted body temperature and wakefulness, and that the degree of food entrainment corresponded to the number of DMH cells remaining post-lesion [128]. Subsequent studies showed that expressing Bmal1 in the SCN of Bmal1 ${ }^{-/-}$mice resulted in a restoration of light-entrainable but not food-entrainable circadian rhythms [129]. Injection of the Bmal1 vector to the DMH restored food-entrainable but not light-entrainable circadian rhythms, suggestive of a possible role of the DMH as the site of the FEO [129]. However, follow-up studies contested these findings, rendering the DMH's contribution to FAA inconclusive at best $[130,131]$. Specifically, robust FAA has been found in rats with lesioned DMH [132], though original results obtained by Gooley et al. 2006 differed in several key areas: food type, lesion method, food locations, and cage configuration, among others. Cage configuration has been ruled out as a major factor [130].

Interestingly, the $\mathrm{DMH}$ has reciprocal feedback to the $\mathrm{SCN}$ whereby it can suppress SCN activity, leading to increased locomotor activity during the rest phase in mice [133]. One potential mechanism for DMH suppression of homeostatic feeding is through BDNF tropomyosin receptor kinase B (TrkB) receptor-expressing DMH neurons [134]. Mutation of the $B d n f$ or TrkB receptor genes leads to obesity both in humans and mice [134]. TrkBexpressing $\mathrm{DMH}\left(\mathrm{DMH}^{\mathrm{TrkB}}\right)$ neurons are also activated post-refeeding or during overnight fasting [134]. Chemogenetic activation of $\mathrm{DMH}^{\mathrm{TrkB}}$ neurons elicits the suppression of food intake during the active phase, whereas chemogenetic inhibition of the same neurons leads to food intake only during the rest phase [134]. However, one study revealed that optogenetic stimulation of inhibitory GABAergic DMH neurons projecting to PVN in particular actually promote food intake [135]. Collectively, these data suggest that the $\mathrm{DMH}$ is still an integral player in the circadian regulation of energy intake, though its contribution to FAA is less clear.

Finally, the VMH has also been postulated to contribute to FAA. The VMH is innervated by multiple hypothalamic regions including the ARC, DMH and LH [136,137], and is characterized by steroidogenic factor 1 (SF1) neurons that are highly sensitive to glucose and leptin [138-140]. Lesions of the VMH do not completely inhibit FAA; although under TRF, mice with VMH lesions display increased arousal-associated with FAA [141]. Five to nine weeks following the VMH lesion surgery, Mistlberger et al. 1984 reported FAA was dampened or absent in VMH lesions rats; however, recovery of FAA was seen during a second phase of RF 14-21 weeks after the surgery [142]. These findings indicated the VMH is not ultimately essential for FAA.

Collectively, studies involving numerous nuclei of the hypothalamus suggest that the FEO may not be localized to one region, but rather dispersed among CNS and peripheral components, with one or more components residing in the hypothalamus to coordinate or respond to peripheral energy status [143-145]. One notable study found that in mice with liver-specific deletion of Per2, FAA was almost completely abolished [146]. Interestingly, using RNA sequencing, researchers identified the liver-derived ketone body, $\beta$-hydroxybutyrate $(\beta \mathrm{OHB})$ as essential for driving FAA in mice [146]. The restoration of FAA from these liver-specific mutant mice by the administration of exogenous $\beta \mathrm{OHB}$ suggests that the liver may also be a fundamental part of the FEO. The influence of peripheral energy states on hypothalamic regulation of rhythmic feeding has also proved to be important reciprocal information. For example, the adipokine adiponectin (ADIPOQ) is released from adipose tissue, and regulates diurnal feeding rhythms through hypothalamic clocks [147]. Adipoq-deficient mice display augmented daytime food intake which is further reinforced by the disrupted expression of core clock gene and appetite-associated hypothalamic genes in the ARC and DMH [147]. For a rough timeline of mechanistic insights, see Figure 3. 


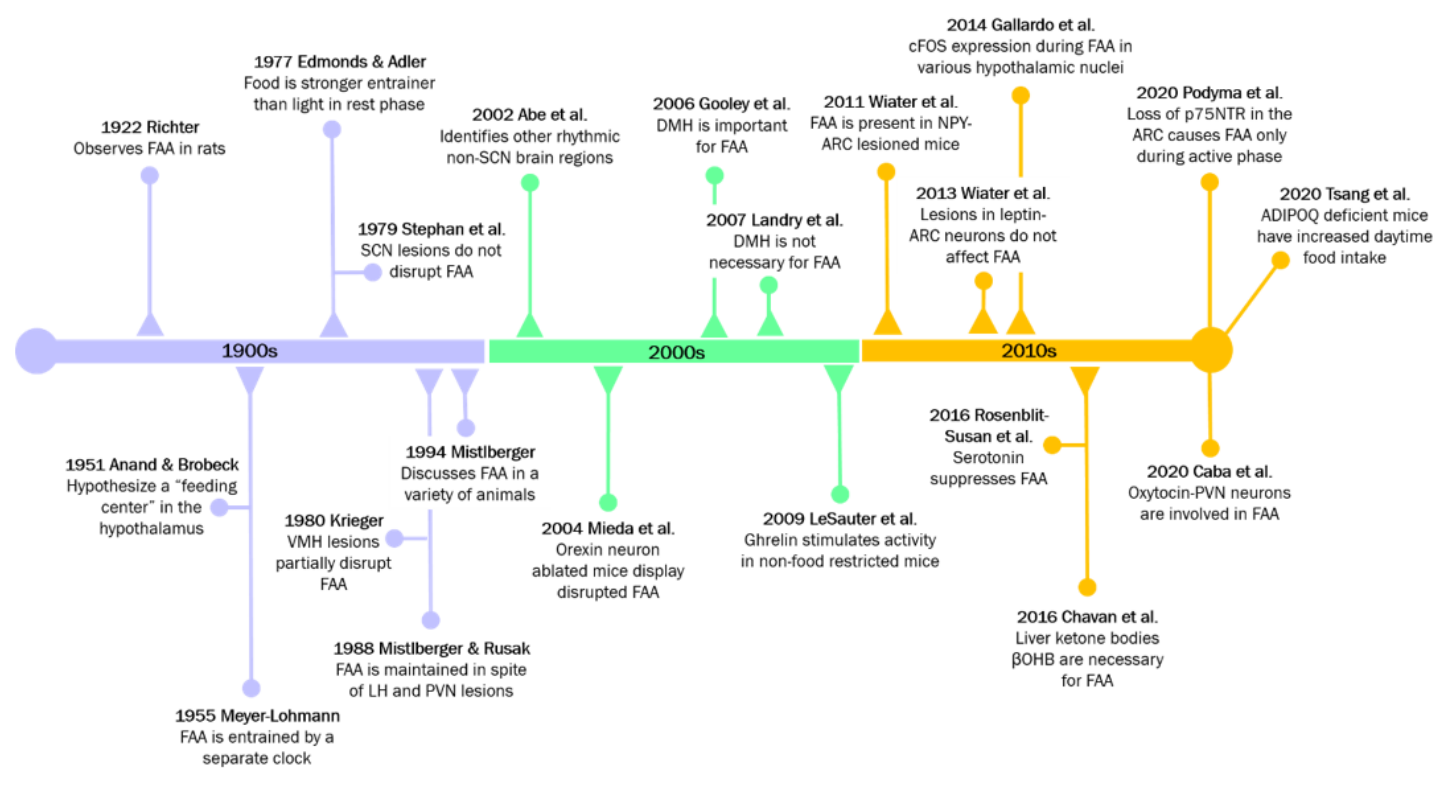

Figure 3. Tracking the "food-entrainable oscillator" through time.

\section{Involvement of the Intrinsic Hypothalamic Clocks in Metabolic Regulation}

Metabolism is inextricably linked to circadian rhythms. High-throughput gene expression analysis has revealed that approximately $5-15 \%$ of the transcriptome shows circadian rhythmicity across a variety of peripheral tissues [148]. Many of these rhythmic genes are involved in important metabolic pathways, such as glucose and lipid metabolism, and oxidative phosphorylation. Genetic animal models of circadian disruption support a direct role of the circadian clock genes in metabolic regulation. For example, mutation of the circadian genes Ck1 in Syrian hamsters and the Fbx13/21 gene ortholog in mice both result in shortened period lengths and increased energy expenditure in mice [149]. In peripheral tissues, liver-specific deletion of Bmal1 leads to fasting-induced hypoglycemia, hypoketosis and impaired mitochondrial fatty acid oxidation [150]. In contrast to the changes seen in mice with Bmal1 deletion in the liver, Pdx1-Cre mice crossed with Bmalf flffl mice (to produce mice lacking Bmal1 in pancreatic tissue) show hypoinsulinemia and hyperglycemia following food intake [151]. Thus, the contrasting effects of clock controlled tissue-specific functions on metabolism underscores the necessity for a higher order control system to integrate and balance these contradicting actions of the circadian clock.

Changes in metabolism are frequently observed by specific alterations in adipose tissue. Two main types of adipose tissue exist in mammals: white adipose tissue (WAT) and brown adipose tissue (BAT). WAT is essential for energy storage while BAT is important for energy burning, otherwise known as thermogenesis [152,153]. Stimulated by cold conditions, BAT is capable of converting the stored triglycerides from WAT into heat to maintain body temperature in an organism [154]. Both adipose types are heavily innervated by the SNS whose projections stem from hypothalamic regions including the ARC, MPOA and the PVN $[155,156]$. Thus, the hypothalamic nuclei utilize their WAT and BAT downstream targets to help maintain energy balance.

\subsection{Circadian Regulation of Metabolism by the ARC}

The ARC plays a crucial role in hypothalamic metabolic regulation. A majority of the $\mathrm{AgRP}$ neuron population reside in the ARC, which communicates directly and indirectly with the SCN $[112,157]$. SCN projections to the ARC contribute to the ARC's sensitivity to glycemia [158]. Lesion or electrolytic ablation of the SCN alters glucose metabolism and impairs the robust circadian firing of POMC $\alpha$-melanocyte-stimulating hormone ( $\alpha-\mathrm{MSH})$ ARC neurons, suggesting that some of ARC rhythmicity is derived in part from SCN communication $[159,160]$. The reciprocal projections are also important; when the ARC 
to SCN projections are severed in rats, rhythmicity in locomotion, corticosterone (CORT) and body temperature is lost under constant darkness [161]. This indicates that ARC rhythmicity is important in synchronizing body wide functions. Multiple studies using either brain slice cultures from transgenic mice or Per1/Per2 in situ hybridization have shown the ARC has its own diurnal rhythmicity expressed by clock genes [71,162]. A recent study using the forebrain-specific BMAL1 KO mice revealed a cell autonomous clock in hypothalamic AgRP neurons, which specifically controls glucose production during fasting and energy intake during the active phase [163]. ARC regulation of energy expenditure occurs via the ANS which indirectly projects through the PVN, VMH and LH $[157,164]$. Leptin fluctuations stimulate AgRP and POMC ARC neurons whose firing through hypothalamic intermediaries stimulate changes in heart rate, blood pressure and hepatic insulin sensitivity $[165,166]$. A crucial ARC neural subtype is the Kisspeptin-expressing neurons (Kiss1) which upon silencing leads to bodyweight gain in mice with dysregulated rhythms in feeding, sleep and body temperature without affecting the circadian expression of the SCN [57]. Dense projections of the Kiss1-ARC neurons to the SPVZ and DMH regions along with wiring to AgRP and POMC neurons in the ARC suggest that the Kiss1-ARC neurons can also converge on these SCN targets to rhythmically regulate their output [57]. An intriguing ARC-neural subtype from a circadian standpoint are pituitary adenylate cyclase-activating polypeptide (PACAP) neurons, PACAP is well known to modulate lightinduced phase resetting in the SCN, and PACAP expression neurons of the ARC can inhibit food intake [167] through a POMC-dependent mechanism [168].

At the molecular level, AMPK activity results in the activation of Agrp expression and the inhibition of Pomc expression through regulation of mTORC1 pathway. AMPK inhibits mTOR signaling preventing mTORC1-mediated oxidative metabolism in POMC neurons which inhibit food intake [104] while also promoting Agrp expression which is otherwise inhibited by the mTOR pathway [169]. Various factors such as insulin, feeding, glucagonlike peptide-1 (GLP-1), and leptin inhibit AMPK activity in the ARC. However, other signals such as ghrelin, hypoglycemia and fasting trigger AMPK-ARC activity (Figure 4). The deletion of SIRT1 from POMC neurons results in increased propensity to develop obesity, specifically in female mice under nutrient stress [170]. Researchers further show decreased energy expenditure due to impaired sympathetic nerve activity in WAT [170]. SIRT1 overexpression in POMC neurons, protects against age-associated weight gain, adipose expansion, and reduced energy expenditure [170]. It is clear from these studies that the ARC has an essential role in rhythmic regulation of body wide metabolism.

\subsection{Circadian Regulation of Metabolism by the PVN}

The PVN lies downstream of the ARC as an integrator of metabolic, neuroendocrine, and satiety signals. Innervated by inhibitory GABAergic projections from the ARC, the excitatory glutamatergic neurons of the PVN terminate on several regions, including the nucleus tractus solarius (NTS) and the parabrachial nucleus (PB) [171-173]. Though its role in energy intake is well accepted, only recently has circadian rhythmicity in the PVN been shown to be a critical regulator of rhythmic energy intake and metabolism. Recently, diurnal variations in the firing of PVN neurons has been observed. Deletion of Bmal1 expression from the PVN of mice inhibits this diurnal firing, leading to reduced diurnal rhythmicity in metabolism [174]. Interestingly, BMAL1 controls the rhythmic expression of GABA-A receptor $\gamma 2$ subunit, and the absence of diurnal $\gamma 2$ rhythms results in loss of diurnal metabolism. Thus, the dynamic responsiveness of BMAL1-driven PVN neurons to GABAergic neurotransmission is essential for mediating diurnal metabolism [174].

Upon activation, the MC4R-PVN neurons signal satiety to decrease food intake. The recent study by Mazier et al. 2019 reports a potential molecular pathway for PVN-mediated satiety [175]. mTORC1 blocks the synthesis of endocannabinoids (eCB) by the PVN neurons; however, AMPK-mediated inhibition of mTORC1 enables eCB production to resume in the PVN. Binding of eCB to the cannabinoid receptor 1 (CB1R) on target POMC-ARC neurons causes increased glutamate release and thus increased glutamatergic input to the 
PVN eliciting reduced food intake [175]. Identifying involvement of mTORC1, which is closely associated with TTFLs in the core clock mechanisms suggests a molecular basis for rhythmic activity of PVN neurons and, therefore, PVN-mediated circadian regulation of metabolism.

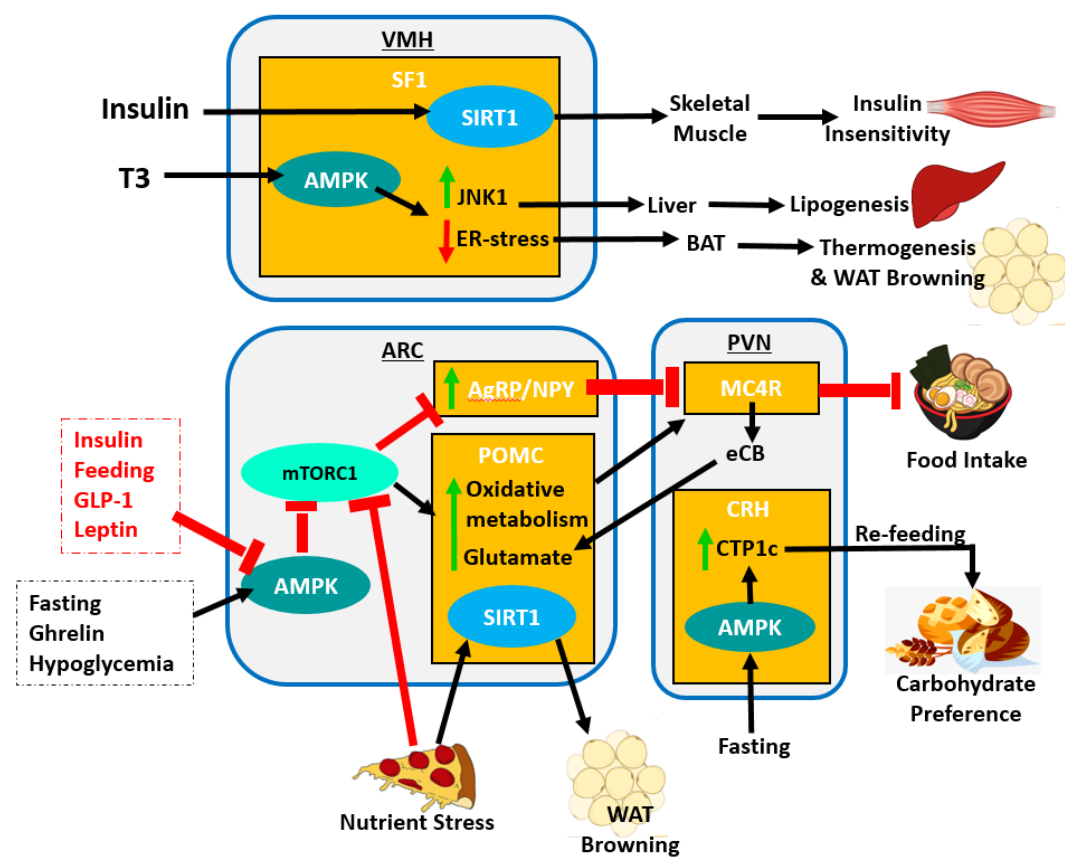

Figure 4. Organism-wide interactions with hypothalamic nuclei alter metabolism and energy homeostasis. AMPK activity is inversely affected by fasting, ghrelin and hypoglycemia compared to insulin, feeding, GLP-1 and leptin. Inhibition of mTORC1 by AMPK increases Agrp, in turn inhibiting MC4R neurons, and promoting energy intake. Alternately, inhibition of AMPK allows mTORC1 activity, which promotes pomc expression, oxidative metabolism, and an increase in activation of the MC4R-PVN neurons that signal satiety. In addition, the activation of MC4R neurons stimulates production of $\mathrm{eCB}$, which feedback to POMC neurons to increase glutamate production, thereby increasing glutamatergic POMC neuronal input to the PVN. Nutrient stress is also a strong inhibitor of mTORC1 activity and a stimulator of SIRT1 expression in POMC-ARC neurons, whose downstream projections initiate WAT browning. Fasting results in AMPK activity in CRH-PVN neurons, resulting in a carbohydrate preference during re-feeding. Other nutrient signals such as insulin also stimulate the SF1-VMH neurons to express SIRT1 that increases insulin insensitivity in skeletal muscle. The thyroid hormone, T3 elicits AMPK activity in the SF1-VMH neurons and through a dual pathway that increases JNK1 and decreases ER stress to produce hepatic lipogenesis and BAT thermogenesis/WAT browning, respectively.

\subsection{Circadian Regulation of Metabolism by the VMH, DMH and LH}

The VMH has been well known for nearly a century for its essential regulation of metabolism [176]. In 1980, Ishikawa and Shimazu found that bilateral electrolytic lesions of the VMH, but not the SCN, substantially reduced the hepatic rhythms of glycogen metabolism in rats fed during the active phase [177]. This implicated a greater role of VMH in rhythmic metabolic homeostasis. Although no overt PER2::LUC rhythms have been observed in explanted VMH organotypic slices [91], hypothalamic lesions of the VMH are known to dramatically increase food consumption, reduce energy expenditure, and induce hyperglycemia and obesity [178]. Knockout of Vglut2 in SF1-VMH neurons results in hypoglycemia in mice [179]. Using mice with Bmal1 ablation in the SF1-VMH neurons, Orozco-Solis et al. 2016 found that these mice displayed augmented BAT activity during their active phase, leading to increased body temperature, increased energy expenditure, and reduced body weight [180]. Like the ARC, the VMH contains PACAP-expressing 
neurons, and PACAP-VMH neurons are sensitive to energy status and involved in glucose homeostasis [181]. Blocking PACAP signaling leads to attenuated leptin-induced hypophagia and hyperthermia [182] indicating that these PACAP-VMH neurons are key mediators of leptin-regulated energy homeostasis.

Interestingly, the liver-derived endocrine hormone fibroblast growth factor 21 (FGF21), which signals starvation to modulate fuel partitioning and metabolism, has substantial effects on the peripheral tissues as well as the CNS to regulate circadian behavior and metabolism [183]. FGF21 can transverse the BBB to directly activate excitatory glutamaterigic VMH neurons eliciting suppressed sugar and carbohydrate intake and increased energy expenditure [184]. FGF21 also affects calcium signaling in glucose-sensitive VMH neurons, resulting in increased glucose sensitivity [184]. Thus, the diurnal expression of this hepatic-derived hormone regulated by lipid metabolism has the ability to diurnally affect specific VMH neurons. Another circadian pathway linked to BAT thermogenesis and energy expenditure begins with the rhythmically oscillating thyroid hormone triiodothyronine (T3) which was identified as an activator of the AMPK pathway in SF1-VMH neurons [185]. AMPK activity in SF1-VMH neurons simultaneously decreases ceramideinduced endoplasmic reticulum stress to promote BAT thermogenesis, while also increasing c-Jun N-terminal kinase (JNK) pathway activation to promote hepatic lipid metabolism through PNS and SNS innervations from the VMH [185]. While AMPK evidently plays a central role in VMH function in the periphery, the presence of the deacetylase SIRT1, stimulated by insulin, is also crucial for normal VMH function. For example, mice lacking SIRT1 are hypersensitive to dietary obesity [186]. Contrastingly, overexpression of SIRT1 in the SF1-VHM neurons render mice more resistant to diet induced obesity due to increased energy expenditure and improved insulin sensitivity in skeletal muscle [186]. These intriguing findings suggest that the non-autonomous clock of the VMH has an important role in rhythmic energy expenditure through regulation of BAT activity.

Sitting dorsal to the VMH and populated by NPY and $\alpha-\mathrm{MSH}$ terminals, the DMH is another primary target of ARC, SCN and SPVZ innervation. Dense DMH projections to the VLPO, the locus coeruleus, and the OX-LH neurons are thought to mediate sleep-wake cycles $[91,187,188]$. Furthermore, a plethora of afferent and efferent connections between hypothalamic sites involved in blood pressure, feeding, metabolism, and thermoregulation, renders the DMH essential to the integration of hypothalamic circadian rhythms $[66,91,187]$. Though Per2::LUC rhythms support the presence of a semi-autonomous oscillator in the $\mathrm{DMH}$, the oscillator dampens more rapidly than that of the ARC [91]. Excitotoxic lesions of the DMH have been shown to attenuate locomotion, feeding, wakefulness and most substantially serum CORT levels [66]. It is clear that energy status strongly controls DMH activity, as it receives visceral afferent signals from the PB and responds to feeding-related peripheral hormones such as leptin, ghrelin and CCK [98]. Selective activation of the $\mathrm{DMH}$ leptin-sensitive $\left(\mathrm{DMH}^{\mathrm{LepRb}}\right)$ neurons by pharmacosynthethic receptors increases BAT thermogenesis and locomotion, resulting in weight reduction without affecting food intake [189]. Moreover, CRE-mediated deletion of $\mathrm{DMH}^{\mathrm{LepRb}}$ neurons produces an opposite effect, highlighting a role for the $\mathrm{DMH}^{\mathrm{LepRb}}$ neurons in controlling energy expenditure [189]. A similarly powerful diurnal hormone is GLP-1 produced both by the intestinal cells and the NTS neurons, of which the GLP-1-NTS neurons synapse onto the glutamatergic DMH neurons [190]. Injections of GLP-1 into the DMH increases BAT thermogenesis, while knockdown of the GLP-1 receptor in the DMH increases adiposity, attenuates energy expenditure and BAT thermogenesis, and increases insulin resistance [190]. Both leptin and GLP-1 are secreted in response to nutrient intake, thus these hormones connect the zeitgeber of food intake to the metabolic clock in part through their interactions with the DMH.

The LH is an extensively interconnected region which consists of numerous distinct neural subtypes such as glucose-sensitive OX neurons which are activated in response to insulin-induced hypoglycemia [191]. Though known for its role in diurnal feeding anticipation and wakefulness, the LH's contribution to metabolic regulation from a circadian 
standpoint has not been fully elucidated. Notably, unlike the PVN whose destruction produces obesity, the destruction of the LH instead results in anorexia [72,192]. Viral tracing experiments reveal bidirectional projections between the ARC, VMH and PVN, indicating interconnectedness in crucial metabolic regions $[193,194]$. Moreover, the OX-LH neurons can regulate BAT thermogenesis to effect overall energy expenditure $[195,196]$. GLP-1 receptors are also present in the LH and are critical for controlling food intake and bodyweight [197]. In all, the LH's diverse inputs and neural subtypes suggests further roles in rhythmic metabolic homeostasis that are yet to be discovered.

\section{The Emerging Regulatory Role of Hypothalamic Clocks in Thirst Anticipation and Fluid Balance}

Since organisms have evolved strong systems to balance metabolism and anticipate feeding, it is reasonable to expect that organisms have also evolved robust methods to anticipate thirst. Mammals in particular experience continual water loss through evaporation of hypotonic fluid during breathing or sweating and through excretion of urine. Thus, maintaining a body fluid balance is reliant on instinctive processes to ensure fluid intake is carried out. In the 1950s, a series of studies were conducted wherein salt was infused into the brains of goats with the hopes of uncovering an osmosensor in the brain responsible for thirst [198,199]. These experiments were successful in revealing a small region known as the subfornical organ (SFO), which lies just outside of the BBB and is capable detecting blood osmolarity. Similarly, the hypothalamic region of the organum vasculosum lamina terminalis (OVLT) also lies outside the BBB to sense blood osmolarity. The SFO and OVLT integrate neural signals and share bidirectional projections with the MPOA to maintain fluid balance; together these nuclei make up the lamina terminalis (LT). The SFO sends glutamatergic projections to the PVN to mediate secretion of AVP [200], and possibly to modulate blood pressure and heart rate via the PVN-SNS [201]. Interestingly, AVP-secreting SCN neurons project to the OVLT to mediate the anticipatory thirst prior to sleep in mice [202]. Later during sleep, AVP-SCN neurons appear to stimulate AVP release by the OVLT, which would trigger renal water retention [203]. This brief surge in drinking prior to sleep in mice results in small 1-2\% fluctuations in plasma osmolarity that would otherwise occur during sleep [202]. Thus, the SCN may help prevent dehydration during sleep and later during sleep promote water retention [204]. The presence of an autonomous circadian clock has been reported in the SFO. Studies utilizing the PER2::LUC mice have revealed that the SFO and the OVLT are strongly rhythmic, and can maintain rhythms for up to 21 days following explanation and forskolin treatment, and possess intrinsic circadian timekeeping properties [205]. These findings suggest that the SFO and OVLT may have greater circadian contribution than previously expected to the daily regulation of thirst and fluid balance.

\section{The Circadian Link between Metabolism, Obesity and Sleep}

As important the role of the hypothalamus is in energy intake, thirst anticipation and metabolic balance, the hypothalamus also plays an essential role in sleep onset and maintenance. Severe ramifications can result from sleep disruption as exemplified by the deleterious effects of chronic jet lag or shift work in humans. Severe sleep disruption in rodent models can even result in death [206]. One study on sleep deprivation found that in normal healthy adults, sleep deprivation led to decreased leptin levels and increased ghrelin and hunger [207,208]. Interestingly, clinical studies suggest a correlation between sleep time and body mass index [209]. Furthermore, clinical trials implementing shortened sleep durations in subjects have been connected to reduced energy expenditure, which affects thermogenesis and can attenuate rhythmicity in core body temperature [210,211]. This is likely due in part to changes in galanin- and GABA-producing neurons of the preoptic area, the activation of which in mice increases sleep, but results in a drop in core body temperature [212]. The disruption of sleep during certain phases of the sleep cycle is also postulated to be connected to metabolic function. When subtle tones are used to disrupt slow wave sleep without waking the subject or shortening sleep time, researchers 
find a corresponding decrease in the subject's glucose tolerance [213]. Moreover, the hypothalamus lies as the central coordinator of sleep patterns, via the SCN projections to the PVN which controls the production and secretion of the rhythmically oscillating sleep hormone melatonin in the pineal gland [214].

Multiple studies have begun to dissect the interconnectedness between hypothalamic control of circadian signaling, metabolic energetics, and sleep-wake cycles $[215,216]$. Two neuron types predominately regulate wakefulness in the hypothalamus: the monoaminergic neurons of the posterior hypothalamus and the OX neurons in the LH. Knockout of Orexin receptor 2 in mice elicits increased susceptibility to obesity [217]. More intriguingly, OX-LH neuronal activity is modulated by glucose [106,218]. Findings from Borniger et al. 2018 further support a linkage between glucose homeostasis and sleep regulation by OX neurons. In a mouse model of breast cancer, tumors were found to deregulate satiety hormones, altering OX neuronal activity, and leading to impaired sleep and glucose metabolism [219]. The VLPO region appears to be involved in sleep induction and maintenance [220]. During wakefulness, these neurons are inhibited by norepinephrine from the locus coeruleus, but non-rapid eye movement sleep (NREM) involves a decline in norepinephrine signaling, and an induction of GABA release from VLPO nucleus neurons. Glucose contributes to sleep onset by exciting sleep-promoting neurons in the VLPO [221]. This potentially corresponds to the sleepiness that creeps up following a meal. Interestingly, though the SCN is always active during the light cycle in diurnal and nocturnal species, the VLPO is always active during the sleep cycle in diurnal and nocturnal species. Though the SCN does have some projections to the VLPO and orexin neurons of the hypothalamus [66], these are not sufficient to maintain rhythmicity in the sleep-wake cycle, and rather the projections to the SPVZ neurons are required [222]. The DMH, which receives heavy innervation from the SPVZ, is thought to integrate circadian signals to regulate sleep and wakefulness $[66,223]$. Recently, SCN projection to CRH-PVN neurons have also been shown to contribute to wakefulness [115], highlighting how much still remains to be uncovered in the hypothalamic role of sleep regulation, circadian rhythms and metabolism.

\section{Circadian Regulation of Metabolism by Neuroendocrine Hormones}

Metabolic homeostasis is predominantly synchronized by the hypothalamic clocks. However, reciprocal relationships between the hypothalamus and peripheral endocrine organs are also required (Figure 5). For example, physiological fluctuations triggered by external stressors, such as changes in blood pressure or glucose levels, can influence SCN neuronal behavior [224]. The sympathetic and parasympathetic branches of the ANS feedback to hypothalamic areas, namely the PVN, which then may indirectly relay the information to the SCN. Furthermore, nutrients and hormones that cross the BBB will be sensed by the ARC-ME complex, and relayed to upstream hypothalamic areas such as the PVN. This is particularly important for the rhythmically fluctuating hunger and satiety hormones, such as leptin and ghrelin. Adipose-derived leptin activates NPY/AgRP and POMC neurons to suppress food intake and stimulate energy expenditure [225]. Leptin also stimulates fatty acid oxidation in skeletal muscle, promotes the uptake of glucose, and improves insulin sensitivity via central and peripheral mechanisms [226,227]. Expression of leptin receptors in POMC neurons of morbidly obese, diabetic and leptin receptordeficient mice $\left(L e p r^{d b / d b}\right)$ results in a reduction in energy intake accompanied by normalized glucose levels and attenuated body weight gain [228]. Interestingly, leptin production in WAT is sufficient to drive diurnal oscillations in circulating leptin, independent of feeding. Adipose-specific ablation of Bmal1 does alter the energy regulation of mice as reflected by reduced levels of triglyceride and polyunsaturated fatty acids circulating through the hypothalamus [190]. In addition, the SCN potentiates the response of ARC neurons to circulating leptin to maintain long-term homeostasis in energy balance [229]. 


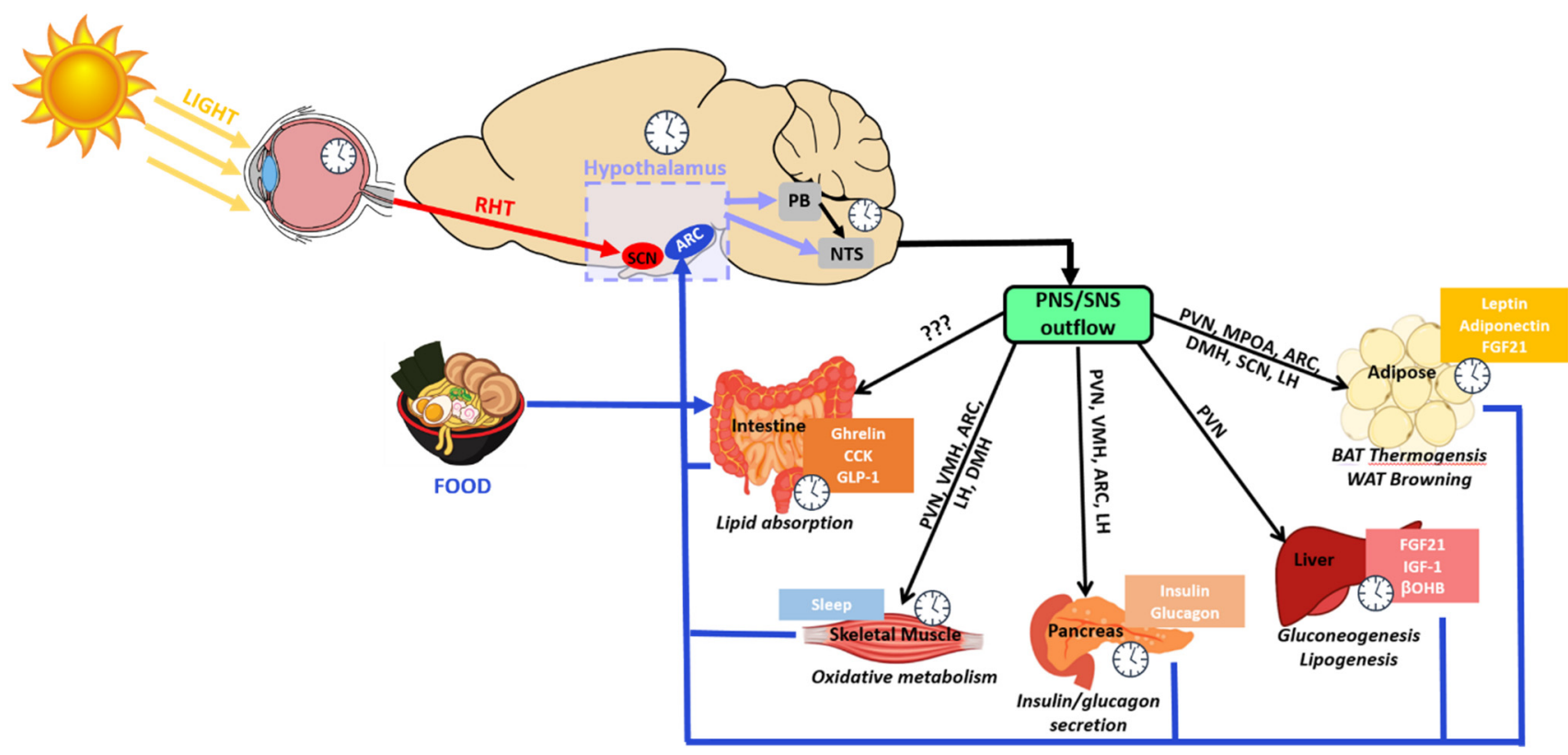

Figure 5. Hypothalamic-mediated circadian regulation of physiological functions. Powerful zeitgebers such as light and food have extensive effects on the circadian activity of cellular and tissue functions. The light-sensitive ipRGCs in the retina send signals to the master clock, the SCN, via the RHT. Food consumption stimulates various metabolic and digestive mechanisms which produce a variety of molecular signals and hormones. Nutrient-sensitive neurons in the circadianregulated hypothalamus pick up the fluctuations in nutrients and hormones and relay the information downstream to the PB and the NTS which regulate the function of tissue processes through the parasympathetic and the sympathetic nervous system (PNS/SNS). With the exception of the intestines, which currently have not been found to have direct innervation from any hypothalamic nuclei, many metabolic-regulating tissues have direct or indirect innervations from various hypothalamic nuclei.

\subsection{Cortisol-Releasing Hormone (CRH)}

A range of neuroendocrine hormones are produced by several hypothalamic nuclei and circulated by secretion into the third ventricle. This includes the well-known oscillatory glucocorticoid hormone, CORT, which is produced by PVN corticotrophin-releasing hormone (CRH) neurons and is critical in the hypothalamic-pituitary-adrenal (HPA) stress axis. Although typically associated with stress, CORT, has been shown to reflect variations in metabolic rate independent of psychological stress [230]. CORT circulation is highly rhythmic, returning to the brain through the ARC. ARC detection of CORT also follows a circadian pattern, dependent on target glucocorticoid and mineralocorticoid receptors in the ARC [231]. Prolonged elevation of glucocorticoid levels in mice results in overconsumption of food via inhibition of CRH-expressing neurons, lowering CORT levels and stimulating NPY expression [232,233]. Additional studies have revealed that both NPY and AgRP expression are differentially responsive to stress via direct innervation from PVN-CRH neurons to the ARC [234-236]. NPY neurons of the ARC innervate the PVN, resulting in NPY-mediated CORT production, food intake, and increased PVN activity $[237,238]$. NPY injection in the PVN of mice results in BAT thermogenesis and increased WAT lipoprotein lipase enzymatic activity [55]. Microarray analyses reveal that rhythmic NPY neurons in part control circadian transcriptional activity in the mouse liver [239]. These findings underscore a bidirectional relationship between the HPA axis and rhythmic ARC and PVN neurons, suggesting an important feedback loop whereby stress-induced chronodisruption influences metabolism and food intake. The recent identification of a neurocircuit whereby GABAergic SCN neurons project to CRH-PVN neurons which excite the OX-LH neurons stimulating wakefulness in mice [115] further highlights the diverse involvement of the $\mathrm{CRH}$ neurons and their CORT production in balancing homeostatic processes. 


\subsection{Melatonin}

The hypothalamic-regulated hormone melatonin is synthesized in the pineal gland and is integral to sleep/wakefulness. Melatonin peaks during the dark phase in both diurnal and nocturnal organisms, whereas most hormones are expressed at opposite phases between nocturnal and diurnal organisms. This suggests that melatonin release is regulated by mechanisms upstream of the unknown biological diurnal/nocturnal switch. Control of melatonin release occurs via direct excitatory glutamatergic inputs from the $\mathrm{SCN}$ to the pineal gland. During the dark phase, direct GABAergic inhibitory signals from the SCN to the PVN inhibit the PVN to pineal gland projections [118,240]. Rhythmicity in melatonin provides essential regulatory control in metabolism; when melatonin synthesis is abolished by pinealectomy, glucose tolerance is impaired and blood glucose rhythmicity is completely lost under ad libitum feeding conditions [241,242]. Thus, the melatonin-mediated regulation of plasma glucose levels is controlled by a delicate balance of glutamatergic and GABAergic pre-autonomic hypothalamic inputs. The daily rise in plasma glucose is produced by inhibition of GABAergic activity at sympathetic pre-autonomic neurons of the PVN, which also increases hepatic glucose output [243]. Altogether, melatonin acts as a key integrator of circadian rhythms and energy metabolism through its effects on the hypothalamus and the periphery.

\subsection{Gut-Derived Polypeptides}

Gut-derived polypeptides have also been implicated in circadian rhythmicity. Apart from the previously discussed GLP-1 and FGF21 hormones, other peripherally-derived hormones also modulate metabolism in a hypothalamus-dependent manner. The gastrinreleasing peptide (GRP) is a mediator of food intake and locomotor activity, and can induce light-like resetting of the SCN [244]. Recently, microbes residing in the gut have been shown to be highly relevant circadian factors in metabolism. Studies have demonstrated that certain microbial taxa and their secretions exhibit diurnal oscillations [245-248]. Additionally, the timing of food intake and chronodisruptions such as jet lag and shift work, can alter the abundance and functions of gut microbes [248,249]. Most interestingly, germ free mice which lack gut microbiota, actually display altered SCN and hepatic transcriptional rhythms, particularly in core clock genes and metabolic pathways [248]. While the gut microbe interaction with the clock machinery is still under investigation, these studies suggest an important relationship that may influence overall energy metabolism. Collectively, rhythmic cross-talk between the extra-SCN hypothalamus and the periphery is critical for metabolic homeostasis.

\section{The Role of Intrinsic Clocks of the Hypothalamus in Obesity}

The intrinsic molecular clock of individual cells drives rhythmic tissue-specific functions, while being entrained by a variety of neuroendocrine, metabolite, hormonal, electrical and temperature signals [148]. A large body of evidence supports the strong role of the clock in energy homeostasis. One of the first demonstrations of the clock being involved in obesity came from a study in 2005, demonstrating that Clock mutant $\left(C_{\text {lock }}{ }^{\Delta 19}\right)$ mice express accelerated hyperphagia, obesity and glucose intolerance when challenged with a high-fat diet (HFD) [250]. A number of circadian mutant rodent models show similar metabolic defects $[17,251]$ and human epidemiological studies also support this association $[18,252,253]$. Circadian disruption through chronic jet lag, shift work, or other means has serious ramifications on human health. Epidemiological studies on shift workers reveal a predisposition to acquiring Type II Diabetes, obesity, cancer, cardiovascular issues and even Alzheimer's disease or other neurological diseases [18,254]. Acute effects of shift work include disrupted sleep-wake cycles and altered meal timing, which is considered to desynchronize the peripheral metabolic clocks and is exacerbated by hormonal imbalance of key satiety signals like leptin and ghrelin $[255,256]$. A short-term study conducted on humans in attempt to stimulate the deleterious effects of jet lag or shift work entailed exposure to a light-dark cycle lengthened to a $28 \mathrm{~h}$ period [257]. Notably, participants 
displayed impaired glucose tolerance and hypoleptinemia, underscoring the immediate effects of circadian disruption on energy metabolism [257]. In short, rotational shift and night shift workers are predisposed to deleterious long-term effects on their metabolic, cardiovascular, neurological and psychological health [257-259].

\subsection{Time-Restricted Feeding}

While the timing of light exposure has robust control over physiological functions and behavior, the timing of food intake also plays a crucial role as well. Time-restricted feeding (TRF) offers a novel non-pharmacological treatment that shortens the window of energy intake to 8-12 h without inadvertently restricting total caloric intake. Preclinical and animal studies clearly demonstrate that TRF can prevent metabolic disease even in mice fed a HFD [260]. Though some studies suggest that TRF activates OX-PVN neurons [261] at the molecular level, TRF strengthens the otherwise dampened rhythms of clock genes, improves mTOR, AMPK and CREB signaling, reduces adiposity and alters the liver metabolome [260,262]. When TRF is applied during the rest phase, the phase of clock gene expression in peripheral tissues reverses, as does the phase of satiety hormones such as leptin, ghrelin and insulin, leading to weight gain and hepatosteatosis [263]. Using a rotating light cycle to mimic shift work, chow-fed mice show altered phases of insulin and CORT secretion, while HFD mice under rotating light have complete loss of rhythmicity in hepatic lipogenic gene expression [264]. Simply delaying feeding time by $4 \mathrm{~h}$ elicits a shift in peripheral clocks and increases weight gain in mice fed HFD [265]. Thus, TRF can actually reverse the deleterious side effects of obesity [266,267]. Even when only adhering to TRF on the weekday and following ad libitum feeding on the weekends in HFD fed mice, the beneficial effects of TRF are still seen [266,268]. At the hypothalamic level, TRF has been shown to restore disrupted locomotor activity in mice with lesioned DMH or jointly lesioned DMH and SCN [269]. Interestingly, hypothalamic leptin sensitivity is improved when TRF is aligned to the daily rhythms of leptin [270]. MC4R neurons in the ARC are highly involved in the regulation of the melanocortin system, which has been demonstrated to mediate the benefits of TRF on energy balance [271]. When the timing of food intake is misaligned with the individuals' intrinsic clock, as is seen in shift workers or chronically jet-lagged individuals, long-term health ramifications exist.

\subsection{The Influences of Diet on the Hypothalamic Clocks}

Diet is also capable of remodeling circadian rhythms behaviorally, transcriptionally, and metabolically $[22,260,272,273]$. For example, feeding mice a ketogenic diet or overexpressing the FGF21 (whose production is stimulated by a ketogenic diet) augments locomotion during the daytime and results in a phase advance in mice [183]. Mice placed on standard HFD have a profound reorganization of their circadian gene expression and metabolite production, in several metabolic tissues, including liver, adipose tissue, and the CNS [22,272,273]. However, hypothalamic PER2::LUC rhythms in the SCN, DMH or ARC appear unaltered under HFD [91]. Is it possible that other hypothalamic regions are affected, or that the Per 2 locus itself is protected from nutrient challenge in the hypothalamus? The so called "Western diet" feeding across 16 weeks in mice results in attenuated neuropeptide expression of Npy, Pomc and AgRP [274]. Interestingly, these ARC neuropeptides are also altered in hypothalamic cell lines derived from global Bmal1-KO mice [274]. The prevalent saturated fatty acid in Western diet known as palmitate is capable of stimulating Npy expression [274]. However, palmitate exposure disrupts Bmal1 and Nampt expression, the latter an integral enzyme of the $\mathrm{NAD}^{+}$salvage pathway, which interacts with the core circadian clock, to induce neuroinflammation in hypothalamic neurons [275]. These findings highlight a mechanistic link between Bmal1 expression and the effects of Western diet on rhythmic expression of energy related hypothalamic neuropeptides. The sensitivity of circadian timekeeping to unhealthy diets or stress is further supported by studies showing that HFD feeding blunts CRH-PVN neuron responsiveness to nutritional challenges and stress [276]. Typically stimulation of these neurons elicits their rapid acti- 
vation; however, clamping CRH-PVN neurons at either high or low levels of activation appears to mimic the same blunting of responsiveness induced by HFD [276]. In both these models, blunting of CRH-PVN neurons results in reduced diurnal rhythmicity in feeding and energy expenditure [276]. AgRP-ARC neurons also display blunted inhibitory activity while under HFD [277]. The PVN, DMH, VMH and ARC have direct innervations to the ANS, some of which terminate in adipose tissue. These extensive projections allow hypothalamic control of WAT and BAT activity [278]. An important leptin-mediated feedback loop between the brain and adipose tissue has been shown to be important for long-term energy balance in mice. Specifically, the disruption of circadian rhythms through chronic jet lag is sufficient to induce leptin resistance independent of obesity risk factors [229].

Interestingly, the PVN has also been uncovered as an influential mediator of food selection. An intriguing study by Okamoto et al. 2018 demonstrates that activation of AMPK-regulated CRH-PVN neurons drives the selection of carbohydrates over fat in mice under a restricted feeding paradigm [279]. Altogether, this discovery that fasting may simulate AMPK to activate a subset of CRH-PVN neurons to induce preference for carbohydrates lays the foundation for further elucidation of the relationship between obesity, diet and the circadian clock.

\subsection{Sex-Specific Differences}

Circadian differences exist between sexes, which may extend to circadian regulation within specific hypothalamic nuclei. For example, recent research revealed that men and women placed in either circadian-aligned or circadian-misaligned conditions across 3 days displayed different physiological changes [280]. Specifically, women expressed circadian misalignment by changes in their energy homeostasis through decreased leptin and increased ghrelin levels [280]. On the other hand, men show increases in hedonic appetite, specifically for carbohydrates [280]. Comparing adolescent girls and boys under similar social jet lag, researchers found that a late chronotype is associated with increased adiposity in girls, but not boys [281]. These studies are two of several that underscore sex-specific differences in the expression of circadian misalignment, suggesting that studies may need to take into account sex when attempting to understand the mechanisms by which chronodisruption alters energy balance and circadian alignment.

\section{The Role of Intrinsic Clocks of the Hypothalamus in Neurological Diseases and Disorders}

A growing body of literature is addressing the mechanisms by which chronodisruption might predispose one to, or exacerbate, existing Alzheimer's disease (AD), Parkinson's disease and other neurological diseases [282-284]. Table 1 presents a summary of neurological diseases that are associated with rhythmic hypothalamic nuclei.

\subsection{Alzheimer's Disease, Neuroinflammation and the Disruption of Sleep-Wake Cycles}

One major contributor to the pathogenesis of $\mathrm{AD}$ is neuroinflammation although its role in $\mathrm{AD}$ is not entirely known. However, accumulating evidence points to microglial and astrocytes whose regulation of CNS response to injury through pro or anti-inflammatory signals have been strongly implicated [285-287]. It is postulated the A $\beta$ plaques stimulate astrocytes and microglial to secrete pro-inflammatory cytokines, chemokines, and reactive oxygen species whose chronic presence dysregulate the immune response that furthers neurodegeneration. Both astrocytes and microglia contain intrinsic clocks that control their morphology, internal processes and contribute to regulation of the sleep-wake cycle [288-290]. Circadian impairment in microglia and astrocytes has been implicated in the neuroinflammatory responses that progress AD [291-293]. One such study found that by disrupting BMAL1 in microglial using a synthetic REV-ERB agonist, an increased inflammatory phenotype appeared in microglial of the amyloid precursor protein knockin (App-KI) mouse model. Moreover, cognitive tests on these 2-month-old App-KI mice treated with the REV-ERB agonist showed microglial activation and cognitive decline [291]. 
Implicating circadian disruption in microglial induces chronic neuroinflammation, which exacerbates AD.

A widely acknowledged symptom in patients with AD-associated dementia or PD is the disruption of sleep-wake cycles. A possible disconnect may exist between the rhythmic oscillations in the SCN and the regions involved in sleep-wake cycle homeostasis such as the $\mathrm{LH}, \mathrm{VMH}$, and $\mathrm{DMH}$. However, pathological changes in the SCN of individuals with AD further implicate the potential role of the circadian clock in disease progression [294-296]. Increasing evidence points to several extra-SCN hypothalamic regions for the early stages of $\mathrm{AD}$ development. Notably, plaques and neuron fibrillary tangles have been observed in the PVN and LH of AD patients [295,297]. Although cognitive decline and dementia are the characteristic hallmarks of AD pathology, they are now recognized as manifestations during late stages of AD [298]. Chronic stress can induce tau pathology, neurodegeneration, and learning impairments in a transgenic mouse model of AD [299]. Treatment with the $\mathrm{CRH}$ receptor 1 antagonist prevents these deleterious effects of chronic stress, indicating that CRH production in the PVN mediated by the HPA axis may contribute to AD pathology [299]. However, studies examining circulating cortisol levels in relation to AD show mixed findings. Thus, further investigations are needed to understand the interactions among stress, circadian rhythms and AD pathology.

A study in 2015 revealed that $A \beta$ plaques induce post-translational degradation of the circadian clock interactor and co-regulator CREB, as well as BMAL1, resulting in disruption of Per2 expression [300]. Interestingly, amyloid levels are shown to peak during the day and decrease during sleep; however, when sleep is disrupted the amyloid levels measured by either cerebral spinal fluid or positron emission tomography generally show an increase [301-303]. In addition, when circadian genes are deleted in a mouse AD model, the mice develop more $A \beta$ plaques than mice without the deleted clock genes while also displaying disrupted amyloid rhythms [301]. At the clinical level, a 2017 study reported a significant dysregulation in Bmal1 expression was associated with early AD [304]. These data suggest a role for circadian genes and circadian rhythmicity in AD pathogenesis.

\subsection{Sundowning Syndrome}

A very interesting behavioral pattern in AD patients is the manifestation of Sundown Syndrome or "sundowing." AD patients with sundowning express temporallydependent behaviors of agitation, aggression, and/or confusion in the afternoon and evening hours [305]. Interestingly, a higher rate of sundowning is reported during the winter months when sunlight exposure is often limited [306]. Melatonin treatment for individuals with sundowning appears to reduce agitated behaviors [307]. The most studied and clinically used therapy is light therapy for sundowning patients, although, in some cases, the SCN may be too degenerated for light therapy to be effective [308]. One study reported that a non-invasive $40 \mathrm{HZ}$ light flicker was sufficient to ameliorate the AD-associated rhythmic disruption in mice [309]. Sundowning severity increases as AD progresses, and light is sometimes recommended during the evening hours to reduce associated agitation. Interestingly, insomnia and hypersomnia are also positively associated with the degree of sundowning symptoms, suggesting a potential corollary factor of sleep fragmentation [310]. The consistent expression of agitation, aggression and/or confusion at a particular time point in the day strongly indicates a disruption of circadian function in the CNS, most likely the hypothalamus. Todd et al. 2018 identified a neurocircuit where the SCN projects to the SPVZ, whose neurons are most active during the early rest phase and innervate the VMH region [311]. Disruption of GABAergic activity in the SPVZ results in a time-dependent increase in aggressiveness in the mice, offering a potential neural circuit involved in sundowning [311]. The VMH region is also associated with the regulation of fear and anxiety, making it a candidate for involvement in sundowning-associated behaviors [312,313]. Further exploration will likely revolve around the rhythmicity of the SCN and its hypothalamic counterparts to elucidate the underlying neurocircuit involved in sundowning. 
Table 1. Hypothalamic nuclei rhythms and associated neurological diseases and disorders.

\begin{tabular}{|c|c|c|c|}
\hline $\begin{array}{c}\text { Neurological } \\
\text { Disease/Disorder }\end{array}$ & Rhythmic Regions Involved & Evidence & References \\
\hline \multirow{3}{*}{ Alzheimer's Disease (AD) } & $\mathrm{SCN}$ & 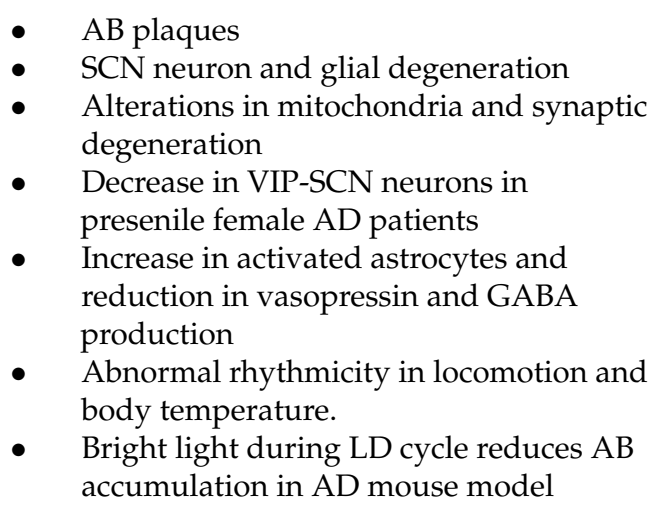 & $\begin{array}{l}{[291,293]} \\
{[292]} \\
{[314]} \\
{[315]} \\
{[316]}\end{array}$ \\
\hline & PVN & 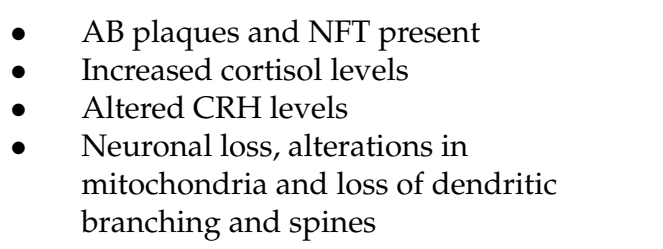 & $\begin{array}{l}{[317]} \\
{[318]} \\
{[319]} \\
{[320]}\end{array}$ \\
\hline & $\mathrm{LH}$ & $\begin{array}{l}\text { - High density of AB plaques and NFT } \\
\text { - } \quad \text { Genetic variations in orexin signaling } \\
\text { receptors are possible risk factors } \\
\text { - } \quad \text { to cognitive decline } \\
\text { - Increased orexin levels are correspond to } \\
\text { increasing sleep fragmentation }\end{array}$ & $\begin{array}{l}{[294]} \\
{[321]} \\
{[322]} \\
{[323]}\end{array}$ \\
\hline \multirow{4}{*}{ Sundowning Syndrome } & $\mathrm{SCN}$ & $\begin{array}{l}\text { Expression of symptoms is light } \\
\text { dependent }\end{array}$ & [302] \\
\hline & PVN & $\begin{array}{l}\text { - Simulation of this region leads to } \\
\text { aggression }\end{array}$ & [324] \\
\hline & $\mathrm{VMH}$ & - Increased salivary cortisol levels & [325] \\
\hline & LH & $\begin{array}{l}\text { - Stimulation of this region leads to } \\
\text { aggression } \\
\text { Agitation corresponds to higher levels of } \\
\text { orexin correspond to increased } \\
\text { fragmented sleep }\end{array}$ & $\begin{array}{l}{[324]} \\
{[326]}\end{array}$ \\
\hline \multirow{4}{*}{$\begin{array}{l}\text { Seasonal Affective Disorder } \\
\text { (SAD) }\end{array}$} & SCN & $\begin{array}{l}\text { - } \quad \text { SCN-Bmal1-KD mice display depressive } \\
\text { behaviors } \\
\text { - } \quad \text { SCN } \rightarrow \text { OX-LH neurons } \rightarrow \text { dorsal raphe } \\
\text { nucleus }\end{array}$ & $\begin{array}{l}{[327]} \\
{[328]}\end{array}$ \\
\hline & PVN & $\begin{array}{l}\text { - } \quad \text { CORT dysregulation } \\
\text { Appetite increase and carbohydrate } \\
\text { preference }\end{array}$ & $\begin{array}{l}{[329]} \\
{[311]}\end{array}$ \\
\hline & LH & $\begin{array}{l}\text { - Disrupted sleep/wake cycle and } \\
\text { insomnia } \\
\text { - } \quad \text { CN } \rightarrow \text { OX-LH neurons } \rightarrow \text { dorsal raphe } \\
\text { nucleus }\end{array}$ & $\begin{array}{l}{[311]} \\
{[328]}\end{array}$ \\
\hline & Brainstem & $\begin{array}{l}\text { - Seasonal and photoperiod alterations in } \\
\text { volume }\end{array}$ & [330] \\
\hline
\end{tabular}


Table 1. Cont.

\begin{tabular}{|c|c|c|c|}
\hline $\begin{array}{l}\text { Neurological } \\
\text { Disease/Disorder }\end{array}$ & Rhythmic Regions Involved & Evidence & References \\
\hline \multirow{3}{*}{ Bipolar Disorder (BD) } & $\mathrm{LH}$ & $\begin{array}{l}\text { - } \\
\text { mania or depressive episodes } \\
\text { - } \quad \text { Reduced plasma OX levels } \\
\text { - Kindling of the LH induces manic activity } \\
\text { in mice }\end{array}$ & $\begin{array}{l}{[312]} \\
{[331]} \\
{[332]}\end{array}$ \\
\hline & PVN & $\begin{array}{l}\text { - } \quad \text { HPA axis is implicated to be involved } \\
\text { Increased cortisol appears to precede } \\
\text { manic episode } \\
\text { - Neuronal loss }\end{array}$ & $\begin{array}{c}{[27,333]} \\
{[334]} \\
{[335]}\end{array}$ \\
\hline & VTA & $\begin{array}{l}\text { Clock expression in VTA of } \text { Clock }^{\Delta 19} \\
\text { mice eliminates mania-like behaviors }\end{array}$ & [336] \\
\hline Schizophrenia & dlPFC & - $\quad$ Altered gene rhythmicity & [337] \\
\hline
\end{tabular}

\subsection{Seasonal Affective Disorder}

This link between our intrinsic clocks and emotional state is not unique to AD or sundowning symptoms; other psychological disorders also have circadian-dependent properties. For example, seasonal affective disorder (SAD) is a type of depression that occurs most commonly during the fall/winter seasons [338]. A reduction in light and changes in the photoperiod length during the fall/winter seasons is presumed to trigger the depressive behaviors characteristic of SAD [339]. Treatment for SAD relies predominantly on phototherapy, in which patients are exposed in the morning to either bright white light or infrared light [327,337]. The finding that SAD prevalence varies depending on the latitude, increasing at higher latitudes where the days are shorter during the fall/winter time, further corroborates the relation between light and emotion [340]. While the underlying mechanism behind SAD is unknown, many consider the clock-regulated hypothalamus to be a prime suspect.

Some mechanistic insights into circadian links to SADs have been revealed in preclinical and human studies both. Bmal1-specific knockdown in the SCN results in a depressive anxiety-like phenotype accompanied by disrupted CORT rhythmicity [341], highlighting a circadian hypothalamic mechanism contributing to emotion. Seasonal changes in hypothalamic gene expression and hormonal activity have been observed in Siberian hamsters [342]. fMRI imaging in SAD patients during exposure to blue light has revealed enhanced responsiveness in the posterior hypothalamus to auditory emotional stimuli, suggesting this region's involvement in SAD [329]. In addition, the dysfunction of hypothalamusrelated functions in SAD individuals is reflected by alterations in sleep, feeding and metabolism $[338,343]$. Appetite is markedly increased in SAD patients, particularly for carbohydrate-rich foods, and weight gain, lethargy, sleepiness and sleep issues such as insomnia also arise more frequently in SAD patients [343,344]. These issues implicate potential roles for the PVN, due to its involvement in carbohydrate preference, and the $\mathrm{LH}$, for its regulation of sleep-wake cycles, in SAD pathology. Moreover, seasonal differences in diurnal cortisol release in SAD patients further implicates a role for the PVN and the HPA axis [336]. The changes in the sleep-wake cycle of SAD patients is also suggestive of hypothalamic OX signaling. Recently, a study highlighted a potential SAD pathway comprised of the SCN, OX-LH neurons and the downstream dorsal raphe nucleus [345]. The quantity of OX hypothalamic neurons was reduced in SAD animals kept in dim light to simulate winter light exposure [346]. Furthermore, exposure to normal light in combination with an OX antagonist led SAD mice to a depressive phenotype [346], suggesting that OX neuron signaling is involved with the depressive behaviors associated with SAD. 


\subsection{Mood Disorders}

Thus, while SAD behavior appear to have a light-dependent origin mediated through a rhythmic hypothalamus, dissimilar neurological phenotypes, including mania, have also been correlated to light-dependent hypothalamic activity. Mania is associated with bipolar disorder (BD) in which individuals commonly vacillate between episodes of depression and mania. BD is often accompanied by disrupted rhythms in the sleep-wake cycle, activity, appetite and hormonal secretions. Moreover, bouts of mania often follow a cyclical, even seasonal pattern, suggesting an underlying circadian mechanism. Clock ${ }^{\Delta 19}$ mice actually express a similar behavioral profile to mania. Treatment with the mood stabilizer lithium, a therapeutic for BD patients, eliminates mania behavior in the $C_{\text {lock }}^{\Delta 19}$ mice, revealing a novel role for CLOCK in mood regulation [347]. Intriguingly, the Clock ${ }^{\Delta 19}$ mice have augmented dopaminergic activity in a region downstream of the hypothalamus, the ventral tegmental area (VTA) [347]. The expression of CLOCK in the VTA of Clock ${ }^{\Delta 19}$ mice often eliminates the manic phenotype [347]. Furthermore, the knockdown of Clock expression in the VTA results in greater depressive behaviors although less hyperactivity [348]. This is perhaps not surprising, as cocaine-induced dopaminergic surge results in a profound reprogramming of circadian gene expression in the striatum, a processes partially dependent on the dopamine 2 receptor and pro-inflammatory peroxisome protein activator receptor gamma (PPAR $\gamma$ ) activity [349].

The VTA is not the only non-hypothalamic region recently uncovered for its rhythmic role in emotion. In schizophrenia, which is characterized by psychotic behaviors, transcript analysis in post-mortem brain tissues schizophrenia patients reveal altered rhythmic gene expression in the dorsolateral prefrontal cortex [330]. The hypothalamic region is still likely involved in schizophrenia as other studies have found increases in hypothalamic volume [350] and attenuated AVP mRNA expression in the hypothalamus [351]. As studies venture beyond the hypothalamus, it is evident the complexity of emotional regulation involves numerous regions. Changes in brainstem substructure volumes have recently been associated with seasonal changes in photoperiod length suggesting a novel role for the brainstem in SAD [352]. A fascinating neurocircuit study by An et al. 2020 uncovered a circadian gated subcortical pathway for the induction of depressive-like behaviors in response to light at night exposure in mice [353]. Electrophysiological studies have demonstrated that the photosensitive ipRGCs, which project to the dorsal perihabenular nucleus $(\mathrm{dpHb})$, have greater excitability during the nighttime. Projections from the $\mathrm{dpHb}$ terminate on the nucleus accumbens to mediate depressive-like behaviors induced by light exposure during the nighttime [353]. This novel circuit potentially underlies the higher propensity for shift workers to develop MDD and anxiety disorders [354].

Mitochondrial metabolic dysfunction may also underlie the behavioral changes associated with mood disorders such as BD and schizophrenia. In mice with forebrain-specific mitochondrial mutations, the behavioral phenotype resembles a manic episode and is accompanied with disrupted circadian expression [355]. The interlocking of intracellular metabolism with circadian machinery via the $\mathrm{NAD}^{+}$salvage pathway suggests a direct link whereby circadian disruption may mediate or worsen metabolic dysfunction, leading to poor cellular health or even cell death. Most likely, however, the metabolic disruptions result in altered neural plasticity and hormone production. For example, CLOCK and $\mathrm{NAD}^{+}$regulation of SIRT1 diurnally antagonize CREB-mediated transcription of tyrosine hydroxylase [356]. In Clock ${ }^{\Delta 19}$ mice, this diurnal regulation is absent, resulting in elevated $\mathrm{TH}$ levels during the daytime [356]. $\mathrm{TH}$ is the rate-limiting enzyme for the synthesis of dopamine, a hormone very likely involved in emotion. Thus, the interactions between core clock mechanisms, metabolism and emotions are more widespread and intertwined than localized circuitry between the SCN and other hypothalamic nuclei.

\section{Treatments and Therapeutics}

Though the circadian mechanisms controlling hypothalamic-driven energy intake and metabolism are still emerging, new data suggest that circadian-enhancing small molecules 
might be a road to improved metabolism and rhythmic activity in the context of nutrient excess and metabolic disease. Examples include the BMAL1-modulating small molecule, Nobiletin (NOB), which acts as the ligand for the Bmal1 locus-activating transcription factor ROR [357]. NOB can boost rhythmicity in energy intake and energy expenditure and inhibit many of the obesity-associated peripheral co-morbidities, such as fatty liver disease and WAT expansion [357-359]. Moreover, in Type II Diabetes, characterized by dysfunction of the pancreatic insulin-secreting $\beta$ cells, treatment with NOB can enhance the circadian amplitudes of $\beta$ cell-mediated insulin secretion in a Bmal1-dependent manner [360,361]. Though the application of such circadian modulators in the context of neurological diseases is in its genesis, it will be important to know to what extent fortification of the internal clock can reverse or prevent neurological diseases and their symptoms. Certainly, internal rhythms reprogram with age [314,362-364] and reinforcement of "youthful" rhythmicity through overexpression of SIRT1 in the SCN of the hypothalamus, or by augmenting $\mathrm{NAD}^{+}$-mediated activity can delay the aging phenotype [315,316]. On a practical level, adherence to a relatively rigid sleep-wake and feeding cycle that is in line with the active phase should at least be strong considerations for preventing metabolic and neurological diseases. Further studies will hopefully reveal the extent to which circadian modulators can be used for treating these diseases successfully. However, preclinical studies are beginning to give us hope that the circadian clock might be exploited to this end.

Author Contributions: R.V.D. and K.E.-M. both contributed to writing of the manuscript. All authors have read and agreed to the published version of the manuscript.

Funding: This work was supported by NIH grant R01DK114037 to K.E.-M.

Institutional Review Board Statement: Not applicable.

Informed Consent Statement: Not applicable.

Acknowledgments: We would like to thank Zheng (Jake) Chen for his instructive comments regarding the manuscript.

Conflicts of Interest: The authors declare no conflict of interest.

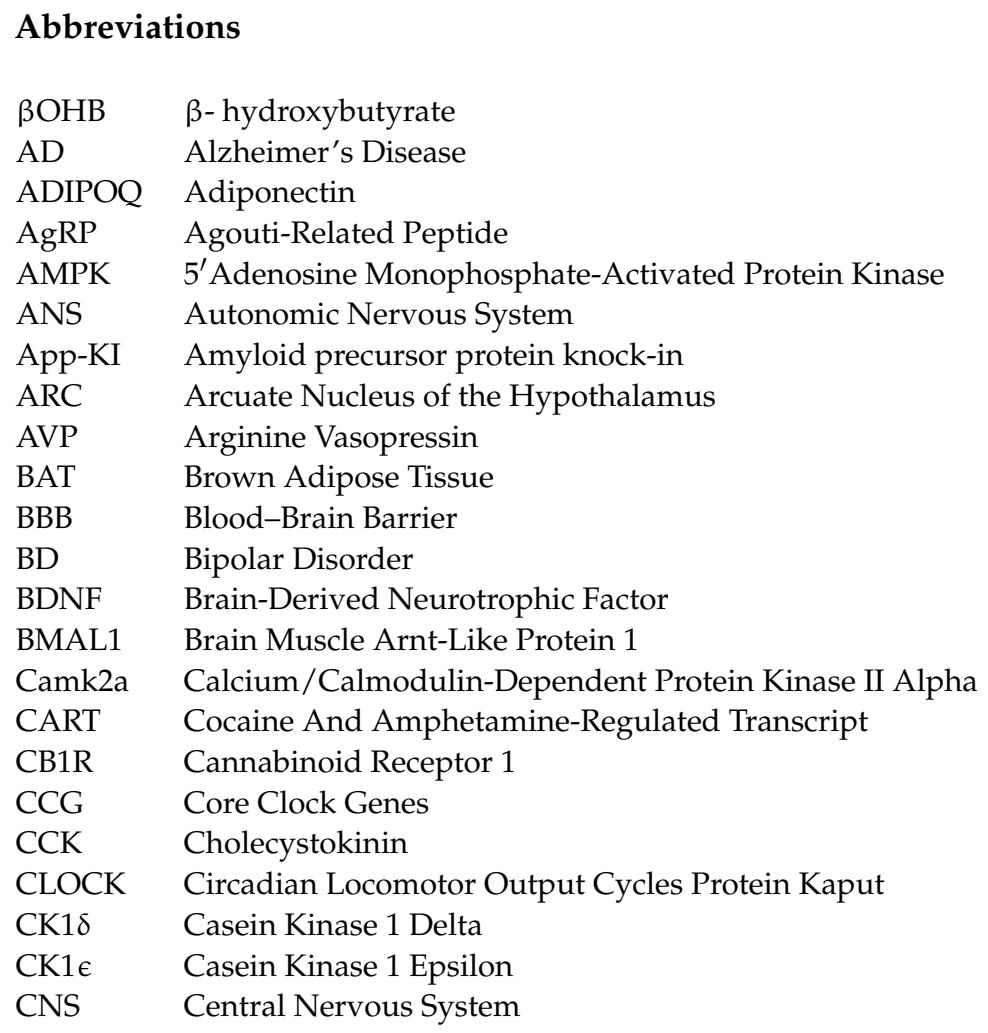




\begin{tabular}{|c|c|}
\hline CORT & Corticotrophin \\
\hline CREB & Camp Response Element-Binding Protein \\
\hline $\mathrm{CRH}$ & Corticotrophin-Releasing Hormone \\
\hline CRY & Cryptochrome \\
\hline CRY1 & Cryptochrome 1 \\
\hline CRY2 & Cryptochrome 2 \\
\hline CTP1c & Carnitine Palmitoyltransferase $1 \mathrm{c}$ \\
\hline dlPFC & Dorsal Lateral Prefrontal Cortex \\
\hline $\mathrm{DMH}$ & Dorsal Medial Hypothalamus \\
\hline $\mathrm{dpHb}$ & Dorsal Perihabenular Nucleus \\
\hline $\mathrm{eCB}$ & Endocannabinoid \\
\hline FAA & Food-Anticipatory Activity \\
\hline FEO & Food-Entrainable Oscillator \\
\hline FGF21 & Fibroblast Growth Factor 21 \\
\hline GABA & Gamma-Aminobutyric Acid \\
\hline GLP-1 & Glucagon-Like Peptide 1 \\
\hline GRP & Gastrin-Releasing Peptide \\
\hline HFD & High-Fat Diet \\
\hline HPA & Hypothalamic-Pituitary Axis \\
\hline ipRGCs & Induced Pluripotent Retinal Ganglion Cells \\
\hline JNK & C-Jun N-Terminal Kinase \\
\hline Kiss1 & Kisspeptin 1 \\
\hline Lep & Leptin \\
\hline $\mathrm{LH}$ & Lateral Hypothalamus \\
\hline $\mathrm{MCH}$ & Melanin-Concentrating Hormone \\
\hline MC4R & Melanocortin Receptor 4 \\
\hline MPOA & Medial Preoptic Area \\
\hline mTOR & Mammalian Target of Rapamycin \\
\hline mTORc1 & Mammalian Target of Rapamycin Complex 1 \\
\hline $\mathrm{NAD}^{+}$ & Nicotinamide Adenine Dinucleotide \\
\hline NAM & Nicotinamide \\
\hline NAMPT & Nicotinamide Phosphoribosyltransferase \\
\hline NMN & Nicotinamide Mononucleotide \\
\hline NOB & Nobiletin \\
\hline NPAS2 & Neuronal PAS Domain Protein 2 \\
\hline NPY & Neuropeptide $Y$ \\
\hline NR1D1 & Nuclear Receptor Subfamily 1 D Member 1 \\
\hline NR1D2 & Nuclear Receptor Subfamily 1 D Member 2 \\
\hline NREM & Non-Rapid Eye Movement \\
\hline NTS & Nucleus Tractus Soilaris \\
\hline OT & Oxytocin \\
\hline OX & Orexin \\
\hline PACAP & Pituitary Adenylate Cyclase-Activating Polypeptide \\
\hline PB & Parabrachial Nucleus \\
\hline PDYN & Prodynophin \\
\hline PER & Period \\
\hline PER1 & Period 1 \\
\hline PER2 & Period 2 \\
\hline PNS & Parasympathetic Nervous System \\
\hline POMC & Proopiomelanocortin \\
\hline PPAR $\gamma$ & Peroxisome Protein Activator Receptor Gamma \\
\hline PVN & Paraventricular Nucleus \\
\hline p75NTR & Neurotrophin Receptor P75 \\
\hline REV-ERB $\alpha$ & Nr1d1 \\
\hline REV-ERB $\beta$ & $\mathrm{Nr} 1 \mathrm{~d} 2$ \\
\hline RF & Restricted Feeding \\
\hline RHT & Retinohypothalamic Tract \\
\hline RORs & Retinoic Acid Receptor-Related Orphan Receptors \\
\hline SAD & Seasonal Affective Disorder \\
\hline
\end{tabular}




$\begin{array}{ll}\text { SCN } & \text { Suprachiasmatic Nucleus } \\ \text { SF1 } & \text { Steroidogenic Factor 1 } \\ \text { SIM1 } & \text { Single-Minded Homolog 1 } \\ \text { SIRT1 } & \text { Sirtuin 1 } \\ \text { SPVZ } & \text { Subparaventricular Zone } \\ \text { TRF } & \text { Time-Restricted Feeding } \\ \text { TRH } & \text { Thyrotropin-Releasing Hormone } \\ \text { TrkB } & \text { Tropomyosin Receptor Kinase B } \\ \text { TRPM2 } & \text { Transient Receptor Potential Cation Channel, Subfamily M, Member 2 } \\ \text { TF } & \text { Transcription Factor } \\ \text { TTLF } & \text { Transcription-Translation Feedback Loop } \\ \text { VLPO } & \text { Ventral Lateral Preoptic Area } \\ \text { VTA } & \text { Ventral Tegmental Area }\end{array}$

\section{References}

1. Takahashi, J.S. Transcriptional architecture of the mammalian circadian clock. Nat. Rev. Genet. 2017, 18, 164-179. [CrossRef]

2. Partch, C.L.; Green, C.B.; Takahashi, J.S. Molecular architecture of the mammalian circadian clock. Trends Cell Biol. 2014, 24, 90-99. [CrossRef] [PubMed]

3. Crumbley, C.; Wang, Y.; Kojetin, D.J.; Burris, T.P. Characterization of the core mammalian clock component, NPAS2, as a REV-ERB $\alpha /$ ROR $\alpha$ target gene. J. Biol. Chem. 2010, 285, 35386-35392. [CrossRef] [PubMed]

4. Gerhart-Hines, Z.; Feng, D.; Emmett, M.J.; Everett, L.J.; Loro, E.; Briggs, E.R.; Bugge, A.; Hou, C.; Ferrara, C.; Seale, P.; et al. The nuclear receptor Rev-erb $\alpha$ controls circadian thermogenic plasticity. Nature 2013, 503, 410-413. [CrossRef] [PubMed]

5. Kornmann, B.; Schaad, O.; Bujard, H.; Takahashi, J.S.; Schibler, U. System-driven and oscillator-dependent circadian transcription in mice with a conditionally active liver clock. PLoS Biol. 2007, 5, e34. [CrossRef] [PubMed]

6. Nakahata, Y.; Sahar, S.; Astarita, G.; Kaluzova, M.; Sassone-Corsi, P. Circadian Control of the NAD+ Salvage Pathway by CLOCK-SIRT1. Science 2009, 324, 654-657. [CrossRef]

7. $\quad$ Bunger, M.K.; Wilsbacher, L.D.; Moran, S.M.; Clendenin, C.; Radcliffe, L.A.; Hogenesch, J.B.; Simon, M.C.; Takahashi, J.S.; Bradfield, C.A. Mop3 is an essential component of the master circadian pacemaker in mammals. Cell 2000, 103, $1009-1017$. [CrossRef]

8. Baggs, J.E.; Price, T.S.; Ditacchio, L.; Panda, S.; Fitzgerald, G.A.; Hogenesch, J.B. Network features of the mammalian circadian clock. PLoS Biol. 2009, 7, e1000052. [CrossRef] [PubMed]

9. Van Der Horst, G.T.J.; Muijtjens, M.; Kobayashi, K.; Takano, R.; Kanno, S.I.; Takao, M.; De Wit, J.; Verkerk, A.; Eker, A.P.M.; Van Leenen, D.; et al. Mammalian Cry1 and Cry2 are essential for maintenance of circadian rhythms. Nature 1999, 398, 627-630. [CrossRef]

10. Bae, K.; Jin, X.; Maywood, E.S.; Hastings, M.H.; Reppert, S.M.; Weaver, D.R. Differential functions of mPer1, mPer2, and mPer3 in the SCN circadian clock. Neuron 2001. [CrossRef]

11. Musiek, E.S.; Xiong, D.D.; Holtzman, D.M. Sleep, circadian rhythms, and the pathogenesis of Alzheimer disease. Exp. Mol. Med. 2015, 47, e148. [CrossRef]

12. Bokenberger, K.; Sjölander, A.; Dahl Aslan, A.K.; Karlsson, I.K.; Åkerstedt, T.; Pedersen, N.L. Shift work and risk of incident dementia: A study of two population-based cohorts. Eur. J. Epidemiol. 2018, 33, 977-987. [CrossRef]

13. van der Vinne, V.; Martin Burgos, B.; Harrington, M.E.; Weaver, D.R. Deconstructing circadian disruption: Assessing the contribution of reduced peripheral oscillator amplitude on obesity and glucose intolerance in mice. J. Pineal Res. 2020, 69, 1-12. [CrossRef]

14. Parsons, M.J.; Moffitt, T.E.; Gregory, A.M.; Goldman-Mellor, S.; Nolan, P.M.; Poulton, R.; Caspi, A. Social jetlag, obesity and metabolic disorder: Investigation in a cohort study. Int. J. Obes. 2015, 39, 842-848. [CrossRef] [PubMed]

15. Cho, K.; Ennaceur, A.; Cole, J.C.; Suh, C.K. Chronic jet lag produces cognitive deficits. J. Neurosci. 2000, 20, 1-5. [CrossRef]

16. Reutrakul, S.; Knutson, K.L. Consequences of Circadian Disruption on Cardiometabolic Health. Sleep Med. Clin. 2015, 10, 455-467. [CrossRef] [PubMed]

17. Shi, S.Q.; Ansari, T.S.; McGuinness, O.P.; Wasserman, D.H.; Johnson, C.H. Circadian disruption leads to insulin resistance and obesity. Curr. Biol. 2013, 23, 372-381. [CrossRef] [PubMed]

18. James, S.M.; Honn, K.A.; Gaddameedhi, S.; Van Dongen, H.P.A. Shift Work: Disrupted Circadian Rhythms and SleepImplications for Health and Well-being. Curr. Sleep Med. Reports 2017, 3, 104-112. [CrossRef] [PubMed]

19. Borbely, A.A. A two process model of sleep regulation. Hum. Neurobiol. 1982, 1, 195-204. [PubMed]

20. Daan, S.; Beersma, D.G.M.; Borbely, A.A. Timing of human sleep: Recovery process gated by a circadian pacemaker. Am. J. Physiol. Regul. Integr. Comp. Physiol. 1984, 15. [CrossRef] [PubMed]

21. Dijk, D.J.; Czeisler, C.A. Paradoxical timing of the circadian rhythm of sleep propensity serves to consolidate sleep and wakefulness in humans. Neurosci. Lett. 1994, 166, 63-68. [CrossRef]

22. Kohsaka, A.; Laposky, A.D.; Ramsey, K.M.; Estrada, C.; Joshu, C.; Kobayashi, Y.; Turek, F.W.; Bass, J. High-Fat Diet Disrupts Behavioral and Molecular Circadian Rhythms in Mice. Cell Metab. 2007, 6, 414-421. [CrossRef] 
23. Navara, K.J.; Nelson, R.J. The dark side of light at night: Physiological, epidemiological, and ecological consequences. J. Pineal Res. 2007, 43, 215-224. [CrossRef] [PubMed]

24. Kolbe, I.; Leinweber, B.; Brandenburger, M.; Oster, H. Circadian clock network desynchrony promotes weight gain and alters glucose homeostasis in mice. Mol. Metab. 2019, 30, 140-151. [CrossRef] [PubMed]

25. Richter, C.P.; Hawkes, C.D. Increased Spontaneous activity and food intake produced in rats by removal of the frontal poles of the brain by. J. Neurol. Psychiatry 1939, 2, 231. [CrossRef]

26. Richter, C.P. Biological clocks in medicine and psychiatry: Shock-phase hypothesis. Proc. Natl. Acad. Sci. USA 1960, 46, 1506-1530. [CrossRef] [PubMed]

27. Moore, R.Y.; Lenn, N.J. A Retinohypothalamic Projection in the Rat. J. Comp. Neurol. 1972, 146, 1-14. [CrossRef]

28. Stephan, F.K.; Zucker, I. Circadian rhythms in drinking behavior and locomotor activity of rats are eliminated by hypothalamic lesions. Proc. Natl. Acad. Sci. USA 1972, 69, 1583-1586. [CrossRef] [PubMed]

29. Moore, R.Y.; Eichler, V.B. Loss of a circadian adrenal corticosterone rhythm following suprachiasmatic lesions in the rat. Brain Res. 1972, 42, 201-206. [CrossRef]

30. Kawamura, H. Hypothalamic “Island” Containing the Suprachiasmatic Nucleus. Neurobiology 1979, 76, 5962-5966.

31. Ralph, M.R.; Foster, R.G.; Davis, F.C. Transplanted Suprachiasmatic Nucleus Deternines Circadian Period. Science 1990, 247, 975-978. [CrossRef] [PubMed]

32. Herzog, E.D.; Hermanstyne, T.; Smyllie, N.J.; Hastings, M.H. Regulating the suprachiasmatic nucleus (SCN) circadian clockwork: Interplay between cell- autonomous and circuit-level mechanisms. Cold Spring Harb. Perspect. Biol. 2017, 9. [CrossRef] [PubMed]

33. Hastings, M.H.; Maywood, E.S.; Brancaccio, M. Generation of circadian rhythms in the suprachiasmatic nucleus. Nat. Rev. Neurosci. 2018, 19, 453-469. [CrossRef] [PubMed]

34. Allaman-Pillet, N.; Roduit, R.; Oberson, A.; Abdelli, S.; Ruiz, J.; Beckmann, J.S.; Schorderet, D.F.; Bonny, C. Circadian regulation of islet genes involved in insulin production and secretion. Mol. Cell. Endocrinol. 2004, 226, 59-66. [CrossRef]

35. Keller, M.; Mazuch, J.; Abraham, U.; Eom, G.D.; Herzog, E.D.; Volk, H.D.; Kramer, A.; Maier, B. A circadian clock in macrophages controls inflammatory immune responses. Proc. Natl. Acad. Sci. USA 2009, 106, 21407-21412. [CrossRef]

36. Schmitt \& Segert NIH Public Access. Bone 2008, 23, 1-7. [CrossRef]

37. Shostak, A.; Meyer-Kovac, J.; Oster, H. Circadian regulation of lipid mobilization in white adipose tissues. Diabetes 2013, 62, 2195-2203. [CrossRef] [PubMed]

38. Zhou, B.; Zhang, Y.; Zhang, F.; Xia, Y.; Liu, J.; Huang, R.; Wang, Y.; Hu, Y.; Wu, J.; Dai, C.; et al. CLOCK/BMAL1 regulates circadian change of mouse hepatic insulin sensitivity by SIRT1. Hepatology 2014, 59, 2196-2206. [CrossRef]

39. Carrasco-Benso, M.P.; Rivero-Gutierrez, B.; Lopez-Minguez, J.; Anzola, A.; Diez-Noguera, A.; Madrid, J.A.; Lujan, J.A.; MartínezAugustin, O.; Scheer, F.A.J.L.; Garaulet, M. Human adipose tissue expresses intrinsic circadian rhythm in insulin sensitivity. FASEB J. 2016, 30, 3117-3123. [CrossRef]

40. Boucher, H.; Vanneaux, V.; Domet, T.; Parouchev, A.; Larghero, J. Circadian clock genes modulate human bone marrow mesenchymal stem cell differentiation, migration and cell cycle. PLoS ONE 2016, 11, e0146674. [CrossRef]

41. Zhang, Y.; Zhang, W.; Liu, C. Integration of peripheral circadian clock and energy metabolism in metabolic tissues. J. Mol. Cell Biol. 2020, 12, 481-485. [CrossRef] [PubMed]

42. Yoo, S.; Yamazaki, S.; Lowrey, P.L.; Shimomura, K.; Ko, C.H.; Buhr, E.D.; Siepka, S.M.; Hong, H.; Oh, W.J.; Yoo, O.J.; et al. PERIOD2: LUCIFERASE real-time reporting of circadian dynamics reveals persistent circadian oscillations in mouse peripheral tissues. Proc. Natl. Acad. Sci. USA 2004, 101, 5339-5346. [CrossRef] [PubMed]

43. Cedernaes, J.; Waldeck, N.; Bass, J. Neurogenetic basis for circadian regulation of metabolism by the hypothalamus. Genes Dev. 2019, 33, 1136-1158. [CrossRef]

44. Greco, C.M.; Corsi, P.S. Circadian blueprint of metabolic pathways in the brain. Nat. Rev. Neurosci. 2019, 20, 71-82. [CrossRef] [PubMed]

45. Begemann, K.; Neumann, A.M.; Oster, H. Regulation and function of extra-SCN circadian oscillators in the brain. Acta Physiol. 2020, 229, 1-14. [CrossRef]

46. Paul, J.R.; Davis, J.A.; Goode, L.K.; Becker, B.K.; Fusilier, A.; Meador-Woodruff, A.; Gamble, K.L. Circadian regulation of membrane physiology in neural oscillators throughout the brain. Eur. J. Neurosci. 2020, 51, 109-138. [CrossRef]

47. Stephan, F.K.; Zucker, I. Circadian Rhythms. Science 1972, 69, 1583-1586.

48. Stephan, F.K. The "other" circadian system: Food as a zeitgeber. J. Biol. Rhythms 2002, 17, 284-292. [CrossRef] [PubMed]

49. Morin, L.P. The circadian visual system. Brain Res. Rev. 1994, 19, 102-127. [CrossRef]

50. Abrahamson, E.E.; Moore, R.Y. Suprachiasmatic nucleus in the mouse: Retinal innervation, intrinsic organization and efferent projections. Brain Res. 2001, 916, 172-191. [CrossRef]

51. Swanson, L.W.; Cowan, W.M. The efferent connections of the suprachiasmatic nucleus of the hypothalamus. J. Comp. Neurol. 1975. [CrossRef] [PubMed]

52. Berk, M.L.; Finkelstein, J.A. An autoradiographic determination of the efferent projections of the suprachiasmatic nucleus of the hypothalamus. Brain Res. 1981. [CrossRef]

53. Kriegsfeld, L.J.; Leak, R.K.; Yackulic, C.B.; Sauter, J.L.E.; Silver, R.A.E. Organization of Suprachiasmatic Nucleus Projections in Syrian Hamsters (Mesocricetus auratus): An Anterograde and Retrograde Analysis. J. Comp. Neurol. 2004, 379, 361-379. [CrossRef] [PubMed] 
54. Melnick, I.; Krishtal, O.A.; Colmers, W.F. Integration of energy homeostasis and stress by parvocellular neurons in rat hypothalamic paraventricular nucleus. J. Physiol. 2020. [CrossRef] [PubMed]

55. Billington, C.J.; Briggs, J.E.; Harker, S.; Grace, M.; Levine, A.S. Neuropeptide Y in hypothalamic paraventricular nucleus: A center coordinating energy metabolism. Am. J. Physiol. Regul. Integr. Comp. Physiol. 1994, 266. [CrossRef]

56. Satoh, N.; Ogawa, Y.; Katsuura, G.; Hayase, M.; Tsuji, T.; Imagawa, K.; Yoshimasa, Y.; Nishi, S.; Hosoda, K.; Nakao, K. The arcuate nucleus as a primary site of satiety effect of leptin in rats. Neurosci. Lett. 1997, 224, 149-152. [CrossRef]

57. Padilla, S.L.; Perez, J.G.; Ben-Hamo, M.; Johnson, C.W.; Sanchez, R.E.A.; Bussi, I.L.; Palmiter, R.D.; de la Iglesia, H.O. Kisspeptin Neurons in the Arcuate Nucleus of the Hypothalamus Orchestrate Circadian Rhythms and Metabolism. Curr. Biol. 2019, 29, 592-604. [CrossRef]

58. Kim, K.W.; Donato, J.; Berglund, E.D.; Choi, Y.H.; Kohno, D.; Elias, C.F.; DePinho, R.A.; Elmquist, J.K. FOXO1 in the ventromedial hypothalamus regulates energy balance. J. Clin. Investig. 2012. [CrossRef]

59. Çakir, I.; Perello, M.; Lansari, O.; Messier, N.J.; Vaslet, C.A.; Nillni, E.A. Hypothalamic Sirt1 regulates food intake in a rodent model system. PLoS ONE 2009. [CrossRef]

60. Leibowitz, S.F. Reciprocal hunger-regulating circuits involving alpha- and beta-adrenergic receptors located, respectively, in the ventromedial and lateral hypothalamus. Proc. Natl. Acad. Sci. USA 1970, 67, 1063-1070. [CrossRef]

61. Berthoud, H.R.; Münzberg, H. The lateral hypothalamus as integrator of metabolic and environmental needs: From electrical self-stimulation to opto-genetics. Physiol. Behav. 2011. [CrossRef] [PubMed]

62. Williams, G.; Harrold, J.A.; Cutler, D.J. The hypothalamus and the regulation of energy homeostasis: Lifting the lid on a black box. Proc. Nutr. Soc. 2000, 59, 385-396. [CrossRef]

63. Arrigoni, E.; Chee, M.J.S.; Fuller, P.M. To eat or to sleep: That is a lateral hypothalamic question. Neuropharmacology 2019, 154, 34-49. [CrossRef]

64. Nader, N.; Chrousos, G.P.; Kino, T. Interactions of the circadian CLOCK system and the HPA axis. Trends Endocrinol. Metab. 2010. [CrossRef] [PubMed]

65. Swanson, L.W.; Kuypers, H.G.J.M. The paraventricular nucleus of the hypothalamus: Cytoarchitectonic subdivisions and organization of projections to the pituitary, dorsal vagal complex, and spinal cord as demonstrated by retrograde fluorescence double-labeling methods. J. Comp. Neurol. 1980, 194, 555-570. [CrossRef]

66. Chou, T.C.; Scammell, T.E.; Gooley, J.J.; Gaus, S.E.; Saper, C.B.; Lu, J. Critical Role of Dorsomedial Hypothalamic Nucleus in a Wide Range of Behavioral Circadian Rhythms. J. Neurosci. 2003, 23, 10691-10702. [CrossRef] [PubMed]

67. Lu, J.; Zhang, Y.H.; Chou, T.C.; Gaus, S.E.; Elmquist, J.K.; Shiromani, R.; Saper, C.B. Contrasting effects of ibotenate lesions of the paraventricular nucleus and subparaventricular zone on sleep-wake cycle and temperature regulation. J. Neurosci. 2001, 21, 4864-4874. [CrossRef] [PubMed]

68. Asala, S.A.; Okano, Y.; Honda, K.; Inoué, S. Effects of medial preoptic area lesions on sleep and wakefulness in unrestrained rats. Neurosci. Lett. 1990, 114, 300-304. [CrossRef]

69. Mondino, A.A.; Hambrecht-wiedbusch, V.; Li, D.; York, A.K. Glutamatergic neurons in the preoptic hypothalamus promote wakefulness, destabilize NREM sleep, suppress REM sleep, and regulate cortical dynamics. bioRxiv 2020. [CrossRef]

70. Tosini, G.; Menaker, M. Circadian Rhythms in Cultured Mammalian Retina. Science 1996, 272, 419-422. [CrossRef] [PubMed]

71. Abe, M.; Herzog, E.D.; Yamazaki, S.; Straume, M.; Tei, H.; Sakaki, Y.; Menaker, M.; Block, G.D. Circadian rhythms in isolated brain regions. J. Neurosci. 2002, 22, 350-356. [CrossRef]

72. Anand, B.; Brobeck, J. Hypothalamic control of food intake in rats and cats * Marked variations in food intake have been described in various species following injury to certain parts of the hypothalamus, including an thalamus, especially lesions in or ventrolateral to the ve. Yale J. Biol. Med. 1951, 24, 123-140. [PubMed]

73. Richter, C.P. A Behavioristic Study of the Activity of the Rat. Comp. Psychol. Monogr. 1922, 1, 56.

74. Aschoff, J.; Von Goetz, C. Effects of Feeding Cycles on Circadian Rhythms in Squirrel Monkeys. J. Biol. Rhythm. 1986. [CrossRef] [PubMed]

75. Mistlberger, R.E. Circadian food-anticipatory activity: Formal models and physiological mechanisms. Neurosci. Biobehav. Rev. 1994, 18, 171-195. [CrossRef]

76. Meyer-Lohmann, J. Über den Einfluß täglicher Futtergaben auf die 24-Stunden-Periodik der lokomotorischen Aktivität weißer Mäuse. Pflugers Arch. Gesamte Physiol. Menschen Tiere 1955. [CrossRef]

77. Edmonds, S.C.; Adler, N.T. Food and light as entrainers of circadian running activity in the rat. Physiol. Behav. 1977, 18, 915-919. [CrossRef]

78. Mendoza, J.; Graff, C.; Dardente, H.; Pevet, P.; Challet, E. Feeding cues alter clock gene oscillations and photic responses in the suprachiasmatic nuclei of mice exposed to a light/dark cycle. J. Neurosci. 2005, 25, 1514-1522. [CrossRef] [PubMed]

79. Izumo, M.; Pejchal, M.; Schook, A.C.; Lange, R.P.; Walisser, J.A.; Sato, T.R.; Wang, X.; Bradfield, C.A.; Takahashi, J.S. Differential effects of light and feeding on circadian organization of peripheral clocks in a forebrain Bmal1 mutant. Elife 2014, 3, 1-27. [CrossRef] [PubMed]

80. Mieda, M.; Sakurai, T. Bmal1 in the nervous system is essential for normal adaptation of circadian locomotor activity and food intake to periodic feeding. J. Neurosci. 2011, 31, 15391-15396. [CrossRef] [PubMed]

81. Puelles, L.; Rubenstein, J.L.R. Forebrain gene expression domains and the evolving prosomeric model. Trends Neurosci. 2003, 26, 469-476. [CrossRef] 
82. Shimogori, T.; Lee, D.A.; Miranda-Angulo, A.; Yang, Y.; Wang, H.; Jiang, L.; Yoshida, A.C.; Kataoka, A.; Mashiko, H.; Avetisyan, M.; et al. A genomic atlas of mouse hypothalamic development. Nat. Neurosci. 2010, 13, 767-775. [CrossRef] [PubMed]

83. Mieda, M.; Hasegawa, E.; Kessaris, N.; Sakurai, T. Fine-tuning circadian rhythms: The importance of Bmal1 expression in the ventral forebrain. Front. Neurosci. 2017, 11, 1-10. [CrossRef] [PubMed]

84. Delezie, J.; Dumont, S.; Sandu, C.; Reibel, S.; Pevet, P.; Challet, E. Rev-erb $\alpha$ in the brain is essential for circadian food entrainment. Sci. Rep. 2016, 6, 1-15. [CrossRef]

85. Cho, H.; Zhao, X.; Hatori, M.; Yu, R.T.; Barish, G.D.; Lam, M.T.; Chong, L.; Ditacchio, L.; Atkins, A.R.; Glass, C.K.; et al. HHS Public Access. Nature 2012, 485, 123-127. [CrossRef]

86. Mang, G.M.; La Spada, F.; Emmenegger, Y.; Chappuis, S.; Ripperger, J.A.; Albrecht, U.; Franken, P. Altered sleep homeostasis in REV-ERB $\alpha$ knockout mice. Sleep 2016, 39, 589-601. [CrossRef] [PubMed]

87. Dudley, C.A.; Erbel-Sieler, C.; Estill, S.J.; Reick, M.; Franken, P.; Pitts, S.N.; McKnight, S.L. Altered patterns of sleep and behavioral adaptability in NPAS2-deficient mice. Science 2003, 301, 379-383. [CrossRef] [PubMed]

88. Gallardo, C.M.; Hsu, C.T.; Gunapala, K.M.; Parfyonov, M.; Chang, C.H.; Mistlberger, R.E.; Steele, A.D. Behavioral and neural correlates of acute and scheduled hunger in C57BL/ 6 mice. PLoS ONE 2014, 9, e95990. [CrossRef]

89. Wang, D.; Opperhuizen, A.L.; Reznick, J.; Turner, N.; Su, Y.; Cooney, G.J.; Kalsbeek, A. Effects of feeding time on daily rhythms of neuropeptide and clock gene expression in the rat hypothalamus. Brain Res. 2017, 1671, 93-101. [CrossRef] [PubMed]

90. Sellix, M.T.; Egli, M.; Poletini, M.O.; Mckee, D.N.T.; Fitch, C.A.; Freeman, M.E. Author Manuscript anatomical and functional characterization of. Am. J. Physiol. 2007, 290, 1-30.

91. Guilding, C.; Hughes, A.T.; Brown, T.M.; Namvar, S.; Piggins, H.D. A riot of rhythms: Neuronal and glial circadian oscillators in the mediobasal hypothalamus. Mol. Brain 2009, 2, 1-19. [CrossRef]

92. Tan, K.; Knight, Z.A.; Friedman, J.M. Ablation of AgRP neurons impairs adaption to restricted feeding. Mol. Metab. 2014, 3, 694-704. [CrossRef] [PubMed]

93. Cedernaes, J.; Huang, W.; Ramsey, K.M.; Waldeck, N.; Cheng, L.; Marcheva, B.; Omura, C.; Kobayashi, Y.; Peek, C.B.; Levine, D.C.; et al. Transcriptional Basis for Rhythmic Control of Hunger and Metabolism within the AgRP Neuron. Cell Metab. 2019, 29, 1078-1091. [CrossRef]

94. Wiater, M.F.; Mukherjee, S.; Li, A.J.; Dinh, T.T.; Rooney, E.M.; Simasko, S.M.; Ritter, S. Circadian integration of sleep-wake and feeding requires NPY receptorexpressing neurons in the mediobasal hypothalamus. Am. J. Physiol. Regul. Integr. Comp. Physiol. 2011, 301, 1569-1583. [CrossRef]

95. Wiater, M.F.; Li, A.J.; Dinh, T.T.; Jansen, H.T.; Ritter, S. Leptin-sensitive neurons in the arcuate nucleus integrate activity and temperature circadian rhythms and anticipatory responses to food restriction. Am. J. Physiol. Regul. Integr. Comp. Physiol. 2013, 305, 949-960. [CrossRef]

96. Henry, F.E.; Sugino, K.; Tozer, A.; Branco, T.; Sternson, S.M. Cell type-specific transcriptomics of hypothalamic energy-sensing neuron responses to weight-loss. Elife 2015, 4, 1-30. [CrossRef] [PubMed]

97. De Araujo, L.D.; Roa, S.L.; Bueno, A.C.; Coeli-Lacchini, F.B.; Martins, C.S.; Uchoa, E.T.; Antunes-Rodrigues, J.; Elias, L.L.; Elias, P.C.; Moreira, A.C.; et al. Restricted feeding schedules modulate in a different manner the expression of clock genes in rat hypothalamic nuclei. Front. Neurosci. 2016. [CrossRef]

98. Elmquist, J.K.; Coppari, R.; Balthasar, N.; Ichinose, M.; Lowell, B.B. Identifying hypothalamic pathways controlling food intake, body weight, and glucose homeostasis. J. Comp. Neurol. 2005, 493, 63-71. [CrossRef]

99. Podyma, B.; Johnson, D.A.; Sipe, L.; Remcho, T.P.; Battin, K.; Liu, Y.; Yoon, S.O.; Deppmann, C.D.; Güler, A.D. The p75 neurotrophin receptor in AgRP neurons is necessary for homeostatic feeding and food anticipation. Elife 2020, 9, 1-19. [CrossRef]

100. Baeza-raja, B.; Eckel-mahan, K.; Zhang, L.; Vagena, E.; Tsigelny, I.F.; Sassone-corsi, P.; Pta, L.J. p75 Neurotrophin Receptor Is a Clock Gene That Regulates Oscillatory Components of Circadian and Metabolic Networks. J. Neurosci. 2013, 33, 10221-10234. [CrossRef] [PubMed]

101. Mori, H.; Inoki, K.; Mu, H.; Opland, D.; Faouzi, M.; Villanueva, E.C.; Ikenoue, T.; Kwiatkowski, D.; Macdougald, O.A.; Myers, M.G.; et al. Critical Role for Hypothalamic mTOR Activity in Energy Balance. Cell Metab. 2009. [CrossRef] [PubMed]

102. Cota, D.; Proulx, K.; Blake Smith, K.A.; Kozma, S.C.; Thomas, G.; Woods, S.C.; Seeley, R.J. Hypothalamic mTOR signaling regulates food intake. Science 2006, 312, 927-930. [CrossRef] [PubMed]

103. Albert, V.; Cornu, M.; Hall, M.N. mTORC1 signaling in Agrp neurons mediates circadian expression of Agrp and NPY but is dispensable for regulation of feeding behavior. Biochem. Biophys. Res. Commun. 2015, 464, 480-486. [CrossRef] [PubMed]

104. Haissaguerre, M.; Ferrière, A.; Simon, V.; Saucisse, N.; Dupuy, N.; André, C.; Clark, S.; Guzman-Quevedo, O.; Tabarin, A.; Cota, D. mTORC1-dependent increase in oxidative metabolism in POMC neurons regulates food intake and action of leptin. Mol. Metab. 2018, 12, 98-106. [CrossRef] [PubMed]

105. Brown, J.A.; Woodworth, H.L.; Leinninger, G.M. To ingest or rest? Specialized roles of lateral hypothalamic area neurons in coordinating energy balance. Front. Syst. Neurosci. 2015, 9, 1-25. [CrossRef] [PubMed]

106. Venner, A.; Karnani, M.M.; Gonzalez, J.A.; Jensen, L.T.; Fugger, L.; Burdakov, D. Orexin neurons as conditional glucosensors: Paradoxical regulation of sugar sensing by intracellular fuels. J. Physiol. 2011, 589, 5701-5708. [CrossRef] [PubMed]

107. Woods, S.C.; Schwartz, M.W.; Baskin, D.G.; Seeley, R.J. Food I Ntake and the R Egulation of body weight. Annu. Rev. Psychol. 2000, 51, 255-277. [CrossRef] 
108. Nakamachi, T.; Matsuda, K.; Maruyama, K.; Miura, T.; Uchiyama, M.; Funahashi, H.; Sakurai, T.; Shioda, S. Regulation by orexin of feeding behaviour and locomotor activity in the goldfish. J. Neuroendocrinol. 2006, 18, 290-297. [CrossRef] [PubMed]

109. Mistlberger, R.E.; Rusak, B. Food-anticipatory circadian rhythms in rats with paraventricular and lateral hypothalamic ablations. J. Biol. Rhythm. 1988, 3, 277-291. [CrossRef]

110. Mieda, M.; Williams, S.C.; Sinton, C.M.; Richardson, J.A.; Sakurai, T.; Yanagisawa, M. Orexin neurons function in an efferent pathway of a food-entrainable circadian oscillator in eliciting food-anticipatory activity and wakefulness. J. Neurosci. 2004, 24, 10493-10501. [CrossRef]

111. Hill, J. PVN pathways controlling energy homeostasis. Indian J. Endocrinol. Metab. 2012. [CrossRef] [PubMed]

112. Saeb-Parsy, K.; Lombardelli, S.; Khan, F.Z.; McDowall, K.; Au-Yong, I.T.H.; Dyball, R.E.J. Neural connections of hypothalamic neuroendocrine nuclei in the rat. J. Neuroendocrinol. 2000. [CrossRef] [PubMed]

113. Xi, D.; Roizen, J.; Lai, M.; Gandhi, N.; Kublaoui, B. Paraventricular nucleus sim1 neuron ablation mediated obesity is resistant to high fat diet. PLoS ONE 2013, 8, e81087. [CrossRef] [PubMed]

114. Tousson, E.; Meissl, H. Suprachiasmatic Nuclei Grafts Restore the Circadian Rhythm in the Paraventricular Nucleus of the Hypothalamus. J. Neurosci. 2004, 24, 2983-2988. [CrossRef] [PubMed]

115. Ono, D.; Mukai, Y.; Hung, C.J.; Chowdhury, S.; Sugiyama, T.; Yamanaka, A. Neuron The mammalian circadian pacemaker regulates wakefulness via CRF neurons in the paraventricular nucleus of the hypothalamus. Sci. Adv. 2020, 6, eabd0384. [CrossRef]

116. Sims, J.S.; Lorden, J.F. Effect of paraventricular nucleus lesions on body weight, food intake and insulin levels. Behav. Brain Res. 1986, 22, 265-281. [CrossRef]

117. Yoshioka, K.; Yoshida, T.; Kawara, H. Lesions of the Hypothalamic Norepinephrine Paraventricular Turnover in Rats. Endocrinol. Jpn. 1989, 36, 187-194.

118. Kalsbeek, A.; Palm, I.F.; La Fleur, S.E.; Scheer, F.A.J.L.; Perreau-Lenz, S.; Ruiter, M.; Kreier, F.; Cailotto, C.; Buijs, R.M. SCN outputs and the hypothalamic balance of life. J. Biol. Rhythms 2006, 21, 458-469. [CrossRef] [PubMed]

119. Caba, M.; Huerta, C.; Meza, E.; Hernández, M.; Rovirosa-Hernández, M.J. Oxytocinergic Cells of the Hypothalamic Paraventricular Nucleus Are Involved in Food Entrainment. Front. Neurosci. 2020, 14, 1-9. [CrossRef] [PubMed]

120. Buijs, R.M.; Kalsbeek, A. Hypothalamic integration of central and peripheral clocks. Nat. Rev. Neurosci. 2001, 2, 1-6. [CrossRef]

121. Buijs, R.M.; Van Eden, C.G. The integration of stress by the hypothalamus, amygdala and prefrontal cortex: Balance between the autonomic nervous system and the neuroendocrine system. Prog. Brain Res. 2000, 126, 117-132. [CrossRef]

122. Li, M.M.; Madara, J.C.; Steger, J.S.; Conley, N.J.; Garfield, A.S.; Lowell, B.B.; Li, M.M.; Madara, J.C.; Steger, J.S.; Krashes, M.J.; et al. The Paraventricular Hypothalamus Regulates Satiety and Prevents Obesity via Two Genetically Article The Paraventricular Hypothalamus Regulates Satiety and Prevents Obesity via Two Genetically Distinct Circuits. Neuron 2019, 102, 653-667.e6. [CrossRef] [PubMed]

123. Xi, D.; Gandhi, N.; Lai, M.; Kublaoui, B.M. Ablation of Sim1 neurons causes obesity through hyperphagia and reduced energy expenditure. PLoS ONE 2012, 7. [CrossRef] [PubMed]

124. Garza, J.C.; Kim, C.S.; Liu, J.; Zhang, W.; Lu, X.Y. Adeno-associated virus-mediated knockdown of melanocortin-4 receptor in the paraventricular nucleus of the hypothalamus promotes high-fat diet-induced hyperphagia and obesity. J. Endocrinol. 2008. [CrossRef] [PubMed]

125. Kalra, S.P.; Dube, M.G.; Sahu, A.; Phelps, C.P.; Kalra, P.S. Neuropeptide Y secretion increases in the paraventricular nucleus in association with increased appetite for food. Proc. Natl. Acad. Sci. USA 1991, 88, 10931-10935. [CrossRef]

126. Santoso, P.; Nakata, M.; Ueta, Y.; Yada, T. CNS control of metabolism: Suprachiasmatic vasopressin to paraventricular oxytocin neurocircuit in the hypothalamus relays light reception to inhibit feeding behavior. Am. J. Physiol. Endocrinol. Metab. 2018, 315, E478-E488. [CrossRef] [PubMed]

127. Mieda, M.; Williams, S.C.; Richardson, J.A.; Tanaka, K.; Yanagisawa, M. The dorsomedial hypothalamic nucleus as a putative food-entrainable circadian pacemaker. Proc. Natl. Acad. Sci. USA 2006, 103, 12150-12155. [CrossRef]

128. Gooley, J.J.; Schomer, A.; Saper, C.B. The dorsomedial hypothalamic nucleus is critical for the expression of food-entrainable circadian rhythms. Nat. Neurosci. 2006, 9, 398-407. [CrossRef]

129. Fuller, P.M.; Lu, J.; Saper, C.B. Food-Entrainable Circadian Rhythms. Science 2008, 320, 1074-1077. [CrossRef] [PubMed]

130. Landry, G.J.; Yamakawa, G.R.; Webb, I.C.; Mear, R.J.; Mistlberger, R.E. The dorsomedial hypothalamic nucleus is not necessary for the expression of circadian food-anticipatory activity in rats. J. Biol. Rhythm. 2007, 22, 467-478. [CrossRef] [PubMed]

131. Mistlberger, R.E.; Buijs, R.M.; Challet, E.; Escobar, C.; Landry, G.J.; Kalsbeek, A.; Pevet, P.; Shibata, S. Food anticipation in Bmal1-/and AAV-Bmal1 rescued mice: A reply to Fuller. J. Circadian Rhythm. 2009, 7, 1-8. [CrossRef]

132. Landry, G.J.; Simon, M.M.; Webb, I.C.; Mistlberger, R.E. Persistence of a behavioral food-anticipatory circadian rhythm following dorsomedial hypothalamic ablation in rats. Am. J. Physiol. Regul. Integr. Comp. Physiol. 2006. [CrossRef]

133. Acosta-Galvan, G.; Yi, C.X.; Van Der Vliet, J.; Jhamandas, J.H.; Panula, P.; Angeles-Castellanos, M.; Del Carmen Basualdo, M.; Escobar, C.; Buijs, R.M. Interaction between hypothalamic dorsomedial nucleus and the suprachiasmatic nucleus determines intensity of food anticipatory behavior. Proc. Natl. Acad. Sci. USA 2011, 108, 5813-5818. [CrossRef] [PubMed]

134. Liao, G.Y.; Kinney, C.E.; An, J.J.; Xu, B. TrkB-expressing neurons in the dorsomedial hypothalamus are necessary and sufficient to suppress homeostatic feeding. Proc. Natl. Acad. Sci. USA 2019, 116, 3256-3261. [CrossRef] [PubMed] 
135. Otgon-Uul, Z.; Suyama, S.; Onodera, H.; Yada, T. Optogenetic activation of leptin- and glucose-regulated GABAergic neurons in dorsomedial hypothalamus promotes food intake via inhibitory synaptic transmission to paraventricular nucleus of hypothalamus. Mol. Metab. 2016. [CrossRef] [PubMed]

136. Cheung, C.C.; Kurrasch, D.M.; Liang, J.K.; Ingraham, H.A. Genetic labeling of steroidogenic factor-1 (SF-1) neurons in mice reveals ventromedial nucleus of the hypothalamus $(\mathrm{VMH})$ circuitry beginning at neurogenesis and development of a separate non-SF-1 neuronal cluster in the ventrolateral VMH. J. Comp. Neurol. 2013. [CrossRef] [PubMed]

137. Hahn, J.D.; Swanson, L.W. Connections of the lateral hypothalamic area juxtadorsomedial region in the male rat. J. Comp. Neurol. 2012. [CrossRef]

138. Minokoshi, Y.; Haque, M.S.; Shimazu, T. Microinjection of leptin into the ventromedial hypothalamus increases glucose uptake in peripheral tissues in rats. Diabetes 1999. [CrossRef]

139. Choi, Y.H.; Fujikawa, T.; Lee, J.; Reuter, A.; Kim, K.W. Revisiting the ventral medial nucleus of the hypothalamus: The roles of SF-1 neurons in energy homeostasis. Front. Neurosci. 2013. [CrossRef]

140. Dhillon, H.; Zigman, J.M.; Ye, C.; Lee, C.E.; McGovern, R.A.; Tang, V.; Kenny, C.D.; Christiansen, L.M.; White, R.D.; Edelstein, E.A.; et al. Leptin directly activates SF1 neurons in the VMH, and this action by leptin is required for normal body-weight homeostasis. Neuron 2006. [CrossRef] [PubMed]

141. Krieger, D.T. Ventromedial hypothalamic lesions abolish food-shifted circadian adrenal and temperature rhythinicity. Endocrinology 1980, 106, 649-654. [CrossRef]

142. Mistlberger, R.E.; Rechtschaffen, A. Recovery of anticipatory activity to restricted feeding in rats with ventromedial hypothalamic lesions. Physiol. Behav. 1984, 33, 227-235. [CrossRef]

143. Davidson, A.J.; Poole, A.S.; Yamazaki, S.; Menaker, M. Is the food-entrainable circadian oscillator in the digestive system? Genes, Brain Behav. 2003, 2, 32-39. [CrossRef]

144. Carneiro, B.T.S.; Araujo, J.F. The food-entrainable oscillator: A network of interconnected brain structures entrained by humoral signals? Chronobiol. Int. 2009, 26, 1273-1289. [CrossRef]

145. Pendergast, J.S.; Yamazaki, S. The Mysterious Food-Entrainable Oscillator: Insights from Mutant and Engineered Mouse Models. J. Biol. Rhythm. 2018, 33, 458-474. [CrossRef]

146. Chavan, R.; Feillet, C.; Costa, S.S.F.; Delorme, J.E.; Okabe, T.; Ripperger, J.A.; Albrecht, U. Liver-derived ketone bodies are necessary for food anticipation. Nat. Commun. 2016, 7, 1-10. [CrossRef] [PubMed]

147. Tsang, A.H.; Koch, C.E.; Kiehn, J.T.; Schmidt, C.X.; Oster, H. An adipokine feedback regulating diurnal food intake rhythms in mice. Elife 2020, 9, 1-25. [CrossRef] [PubMed]

148. Zhang, R.; Lahens, N.F.; Ballance, H.I.; Hughes, M.E.; Hogenesch, J.B. A circadian gene expression atlas in mammals: Implications for biology and medicine. Proc. Natl. Acad. Sci. USA 2014, 111, 16219-16224. [CrossRef] [PubMed]

149. Lowrey, P.L.; Shimomura, K.; Antoch, M.P.; Yamazaki, S.; Zemenides, P.D.; Ralph, M.R.; Menaker, M.; Takahashi, J.S. Positional syntenic cloning and functional characterization of the mammalian circadian mutation tau. Science 2000, 288, 483-491. [CrossRef] [PubMed]

150. Lamia, K.A.; Storch, K.F.; Weitz, C.J. Physiological significance of a peripheral tissue circadian clock. Proc. Natl. Acad. Sci. USA 2008, 105, 15172-15177. [CrossRef]

151. Sadacca, L.A.; Lamia, K.A.; DeLemos, A.S.; Blum, B.; Weitz, C.J. An intrinsic circadian clock of the pancreas is required for normal insulin release and glucose homeostasis in mice. Diabetologia 2011, 54, 120-124. [CrossRef]

152. Seale, P.; Conroe, H.M.; Estall, J.; Kajimura, S.; Frontini, A.; Ishibashi, J.; Cohen, P.; Cinti, S.; Spiegelman, B.M. Prdm16 determines the thermogenic program of subcutaneous white adipose tissue in mice. J. Clin. Investig. 2011. [CrossRef] [PubMed]

153. Fisher, F.F.; Kleiner, S.; Douris, N.; Fox, E.C.; Mepani, R.J.; Verdeguer, F.; Wu, J.; Kharitonenkov, A.; Flier, J.S.; Maratos-Flier, E.; et al. FGF21 regulates PGC-1 $\alpha$ and browning of white adipose tissues in adaptive thermogenesis. Genes Dev. 2012, 26, 271-281. [CrossRef] [PubMed]

154. Klingenspor, M. Cold-induced recruitment of brown adipose tissue thermogenesis. Exp. Physiol. 2003, 88, 141-148. [CrossRef] [PubMed]

155. Bartness, T.J.; Bamshad, M. Innervation of mammalian white adipose tissue: Implications for the regulation of total body fat. Am. J. Physiol. Regul. Integr. Comp. Physiol. 1998, 275, 1399-1411. [CrossRef]

156. Wang, P.; Loh, K.H.; Wu, M.; Morgan, D.A.; Schneeberger, M.; Yu, X.; Chi, J.; Kosse, C.; Kim, D.; Rahmouni, K.; et al. A leptin-BDNF pathway regulating sympathetic innervation of adipose tissue. Nature 2020, 583, 839-844. [CrossRef]

157. Yi, C.X.; Van Der Vliet, J.; Dai, J.; Yin, G.; Ru, L.; Buijs, R.M. Ventromedial arcuate nucleus communicates peripheral metabolic information to the suprachiasmatic nucleus. Endocrinology 2006, 147, 283-294. [CrossRef] [PubMed]

158. Chao, D.H.M.; León-Mercado, L.; Foppen, E.; Guzmán-Ruiz, M.; Basualdo, M.C.; Escobar, C.; Buijs, R.M. The suprachiasmatic nucleus modulates the sensitivity of arcuate nucleus to hypoglycemia in the male rat. Endocrinology 2016, 157, 3439-3451. [CrossRef]

159. Guzmán-Ruiz, M.; Saderi, N.; Cazarez-Márquez, F.; Guerrero-Vargas, N.N.; Basualdo, M.C.; Acosta-Galván, G.; Buijs, R.M. The suprachiasmatic nucleus changes the daily activity of the arcuate nucleus $\alpha$-MSH neurons in male rats. Endocrinology 2014, 155, 525-535. [CrossRef]

160. Buijs, F.N.; Guzmán-Ruiz, M.; León-Mercado, L.; Basualdo, M.C.; Escobar, C.; Kalsbeek, A.; Buijs, R.M. Suprachiasmatic nucleus interaction with the arcuate nucleus; Essential for organizing physiological rhythms. eNeuro 2017, 4, 1-14. [CrossRef] 
161. Shieh, K.R.; Yang, S.C.; Lu, X.Y.; Akil, H.; Watson, S.J. Diurnal rhythmic expression of the rhythm-related genes, rPeriod1, rPeriod2, and rClock, in the rat brain. J. Biomed. Sci. 2005. [CrossRef] [PubMed]

162. Cedernaes, J.; Huang, W.; Ramsey, K.M.; Waldeck, N.; Marcheva, B.; Peek, C.B.; Levine, D.C.; Awatramani, R.; Bradfield, C.A.; Wang, X.A.; et al. Transcriptional basis for rhythmic control of hunger and metabolism within the AgRP neuron. Sleep Med. 2019. [CrossRef]

163. Uyama, N.; Geerts, A.; Reynaert, H. Neural connections between the hypothalamus and the liver. Anat. Rec. Part A Discov. Mol. Cell. Evol. Biol. 2004, 280, 808-820. [CrossRef] [PubMed]

164. Bell, B.B.; Harlan, S.M.; Morgan, D.A.; Guo, D.F.; Rahmouni, K. Differential contribution of POMC and AgRP neurons to the regulation of regional autonomic nerve activity by leptin. Mol. Metab. 2018, 8, 1-12. [CrossRef] [PubMed]

165. Yi, C.; Fliers, E.; Buijs, R.M. circadian disruption and scn control of energy. FEBS Lett. 2012, 585, 1412-1426. [CrossRef]

166. Resch, J.M.; Maunze, B.; Phillips, K.A.; Choi, S.J. Inhibition of food intake by PACAP in the hypothalamic ventromedial nuclei is mediated by NMDA receptors. Physiol. Behav. 2014. [CrossRef] [PubMed]

167. Mounien, L.; Do Rego, J.C.; Bizet, P.; Boutelet, I.; Gourcerol, G.; Fournier, A.; Brabet, P.; Costentin, J.; Vaudry, H.; Jégou, S. Pituitary adenylate cyclase-activating polypeptide inhibits food intake in mice through activation of the hypothalamic melanocortin system. Neuropsychopharmacology 2009, 34, 424-435. [CrossRef]

168. Morrison, C.D.; Xi, A.; White, C.L.; Ye, J.; Martin, R.J. Amino acids inhibit Agrp gene expression via an mTOR-dependent mechanism. Am. J. Physiol. Endocrinol. Metab. 2007, 293, 165-171. [CrossRef]

169. Sasaki, T.; Kikuchi, O.; Shimpuku, M.; Susanti, V.Y.; Yokota-Hashimoto, H.; Taguchi, R.; Shibusawa, N.; Sato, T.; Tang, L.; Amano, K.; et al. Hypothalamic SIRT1 prevents age-associated weight gain by improving leptin sensitivity in mice. Diabetologia 2014. [CrossRef] [PubMed]

170. Geerling, J.C.; Shin, J.W.; Chimenti, P.C.; Loewy, A.D. Paraventricular hypothalamic nucleus: Axonal projections to the brainstem. J. Comp. Neurol. 2010. [CrossRef]

171. Ferguson, A.V.; Latchford, K.J.; Sanon, W.K. The paraventricular nucleus of the hypothalamus-A potential target for integrative treatment of autonomic dysfunction. Expert Opin. Ther. Targets 2008, 12, 717-727. [CrossRef]

172. Geerling, J.J.; Boon, M.R.; Kooijman, S.; Parlevliet, E.T.; Havekes, L.M.; Romijn, J.A.; Meurs, I.M.; Rensen, P.C.N. Sympathetic nervous system control of triglyceride metabolism: Novel concepts derived from recent studies. J. Lipid Res. 2014, 55, 180-189. [CrossRef] [PubMed]

173. Kim, E.R.; Xu, Y.; Cassidy, R.M.; Lu, Y.; Yang, Y.; Tian, J.; Li, D.P.; Van Drunen, R.; Ribas-Latre, A.; Cai, Z.L.; et al. Paraventricular hypothalamus mediates diurnal rhythm of metabolism. Nat. Commun. 2020, 11, 1-17. [CrossRef] [PubMed]

174. Mazier, W.; Saucisse, N.; Simon, V.; Cannich, A.; Marsicano, G.; Massa, F.; Cota, D. mTORC1 and CB1 receptor signaling regulate excitatory glutamatergic inputs onto the hypothalamic paraventricular nucleus in response to energy availability. Mol. Metab. 2019, 28, 151-159. [CrossRef]

175. King, B.M. The rise, fall, and resurrection of the ventromedial hypothalamus in the regulation of feeding behavior and body weight. Physiol. Behav. 2006, 87, 221-244. [CrossRef]

176. Ishikawa, K.; Shimazu, T. Circadian rhythm of liver glycogen metabolism in rats: Effects of hypothalamic lesions. Am. J. Physiol. Endocrinol. Metab. 1980. [CrossRef]

177. Shimizu, N.; Oomura, Y.; Plata-Salamán, C.R.; Morimoto, M. Hyperphagia and obesity in rats with bilateral ibotenic acid-induced lesions of the ventromedial hypothalamic nucleus. Brain Res. 1987, 416, 153-156. [CrossRef]

178. Tong, Q.; Ye, C.P.; McCrimmon, R.J.; Dhillon, H.; Choi, B.; Kramer, M.D.; Yu, J.; Yang, Z.; Christiansen, L.M.; Lee, C.E.; et al. Synaptic Glutamate Release by Ventromedial Hypothalamic Neurons Is Part of the Neurocircuitry that Prevents Hypoglycemia. Cell Metab. 2007, 5, 383-393. [CrossRef] [PubMed]

179. Orozco-Solis, R.; Aguilar-Arnal, L.; Murakami, M.; Peruquetti, R.; Ramadori, G.; Coppari, R.; Sassone-Corsi, P. The circadian clock in the ventromedial hypothalamus controls cyclic energy expenditure. Cell Metab. 2016, 23, 467-478. [CrossRef]

180. Khodai, T.; Nunn, N.; Worth, A.A.; Feetham, C.H.; Belle, M.D.C.; Piggins, H.D.; Luckman, S.M. PACAP neurons in the ventromedial hypothalamic nucleus are glucose inhibited and their selective activation induces hyperglycaemia. Front. Endocrinol. 2018, 9, 1-9. [CrossRef]

181. Hawke, Z.; Ivanov, T.R.; Bechtold, D.A.; Dhillon, H.; Lowell, B.B.; Luckman, S.M. PACAP Neurons in the Hypothalamic Ventromedial Nucleus Are Targets of Central Leptin Signaling. J. Neurosci. 2009, 29, 14828-14835. [CrossRef]

182. Bookout, A.L.; De Groot, M.H.M.; Owen, B.M.; Lee, S.; Gautron, L.; Lawrence, H.L.; Ding, X.; Elmquist, J.K.; Takahashi, J.S.; Mangelsdorf, D.J.; et al. FGF21 regulates metabolism and circadian behavior by acting on the nervous system. Nat. Med. 2013. [CrossRef]

183. Jensen-Cody, S.O.; Flippo, K.H.; Claflin, K.E.; Yavuz, Y.; Sapouckey, S.A.; Walters, G.C.; Usachev, Y.M.; Atasoy, D.; Gillum, M.P.; Potthoff, M.J. FGF21 Signals to Glutamatergic Neurons in the Ventromedial Hypothalamus to Suppress Carbohydrate Intake. Cell Metab. 2020. [CrossRef] [PubMed]

184. Martínez-Sánchez, N.; Seoane-Collazo, P.; Contreras, C.; Varela, L.; Villarroya, J.; Rial-Pensado, E.; Buqué, X.; Aurrekoetxea, I.; Delgado, T.C.; Vázquez-Martínez, R.; et al. Hypothalamic AMPK-ER Stress-JNK1 Axis Mediates the Central Actions of Thyroid Hormones on Energy Balance. Cell Metab. 2017. [CrossRef] [PubMed]

185. Ramadori, G.; Fujikawa, T.; Anderson, J.; Berglund, E.D.; Frazao, R.; Michán, S.; Vianna, C.R.; Sinclair, D.A.; Elias, C.F.; Coppari, R. SIRT1 deacetylase in SF1 neurons protects against metabolic imbalance. Cell Metab. 2011, 14, 301-312. [CrossRef] 
186. Thompson, R.H.; Canteras, N.S.; Swanson, L.W. Organization of projections from the dorsomedial nucleus of the hypothalamus: A PHA-L study in the rat. J. Comp. Neurol. 1996. [CrossRef]

187. Sakurai, T.; Amemiya, A.; Ishii, M.; Matsuzaki, I.; Chemelli, R.M.; Tanaka, H.; Williams, S.C.; Richardson, J.A.; Kozlowski, G.P.; Wilson, S.; et al. Orexins and orexin receptors: A family of hypothalamic neuropeptides and G protein-coupled receptors that regulate feeding behavior. Cell 1998. [CrossRef]

188. Chen, K.S.; Xu, M.; Zhang, Z.; Chang, W.C.; Gaj, T.; Schaffer, D.V.; Dan, Y. A Hypothalamic Switch for REM and Non-REM Sleep. Neuron 2018. [CrossRef] [PubMed]

189. Moriguchi, T.; Sakurai, T.; Nambu, T.; Yanagisawa, M.; Goto, K. Neurons containing orexin in the lateral hypothalamic area of the adult rat brain are activated by insulin-induced acute hypoglycemia. Neurosci. Lett. 1999. [CrossRef]

190. Gold, R.M. Hypothalamic obesity: The myth of the ventromedial nucleus. Science 1973. [CrossRef] [PubMed]

191. Bernardis, L.L.; Bellinger, L.L. The lateral hypothalamic area revisited: Neuroanatomy, body weight regulation, neuroendocrinology and metabolism. Neurosci. Biobehav. Rev. 1993. [CrossRef]

192. Oomura, Y.; Ooyama, H.; Sugimori, M.; Nakamura, T.; Yamada, Y. Glucose inhibition of the glucose-sensitive neurone in the rat lateral hypothalamus. Nature 1974. [CrossRef] [PubMed]

193. Berthoud, H.R.; Patterson, L.M.; Sutton, G.M.; Morrison, C.; Zheng, H. Orexin inputs to caudal raphé neurons involved in thermal, cardiovascular, and gastrointestinal regulation. Histochem. Cell Biol. 2005. [CrossRef]

194. Martins, L.; Seoane-Collazo, P.; Contreras, C.; González-García, I.; Martínez-Sánchez, N.; González, F.; Zalvide, J.; Gallego, R.; Diéguez, C.; Nogueiras, R.; et al. A Functional Link between AMPK and Orexin Mediates the Effect of BMP8B on Energy Balance. Cell Rep. 2016, 16, 2231-2242. [CrossRef]

195. López-Ferreras, L.; Richard, J.E.; Noble, E.E.; Eerola, K.; Anderberg, R.H.; Olandersson, K.; Taing, L.; Kanoski, S.E.; Hayes, M.R.; Skibicka, K.P. Lateral hypothalamic GLP-1 receptors are critical for the control of food reinforcement, ingestive behavior and body weight. Mol. Psychiatry 2018, 23, 1157-1168. [CrossRef]

196. Everson, C.A.; Bergmann, B.M.; Rechtschaffen, A. Sleep deprivation in the rat: III. Total sleep deprivation. Sleep 1989, $12,13-21$. [CrossRef] [PubMed]

197. Taheri, S.; Lin, L.; Austin, D.; Young, T.; Mignot, E. Short sleep duration is associated with reduced leptin, elevated ghrelin, and increased body mass index. PLoS Med. 2004. [CrossRef]

198. ANDERSSON., B. The Effect of Injections of Hypertonic NaCl-Solutions into Different Parts of the Hypothalamus of Goats. Acta Physiol. Scand. 1953. [CrossRef]

199. ANDERSSON, B.; McCANN, S.M. Drinking, Antidiuresis and Milk Ejection from Electrical Stimulation within the Hypothalamus of the Goat. Acta Physiol. Scand. 1955. [CrossRef]

200. Llewellyn, T.; Zheng, H.; Liu, X.; Xu, B.; Patel, K.P. Median preoptic nucleus and subfornical organ drive renal sympathetic nerve activity via a glutamatergic mechanism within the paraventricular nucleus. Am. J. Physiol. Regul. Integr. Comp. Physiol. 2012. [CrossRef] [PubMed]

201. Gabor, A.; Leenen, F.H.H. Central neuromodulatory pathways regulating sympathetic activity in hypertension. J. Appl. Physiol. 2012, 113, 1294-1303. [CrossRef] [PubMed]

202. Gizowski, C.; Zaelzer, C.; Bourque, C.W. Clock-driven vasopressin neurotransmission mediates anticipatory thirst prior to sleep. Nature 2016, 537, 685-688. [CrossRef] [PubMed]

203. Trudel, E.; Bourque, C.W. Central clock excites vasopressin neurons by waking osmosensory afferents during late sleep. Nat. Neurosci. 2010. [CrossRef]

204. Zimmerman, C.A.; Leib, D.E.; Knight, Z.A. Neural circuits underlying thirst and fluid homeostasis. Nat. Rev. Neurosci. 2017, 18, 459-469. [CrossRef] [PubMed]

205. Northeast, R.C.; Chrobok, L.; Hughes, A.T.L.; Petit, C.; Piggins, H.D. Keeping time in the lamina terminalis: Novel oscillator properties of forebrain sensory circumventricular organs. FASEB J. 2020, 34, 974-987. [CrossRef]

206. Chaput, J.P.; Després, J.P.; Bouchard, C.; Tremblay, A. Association of sleep duration with type 2 diabetes and impaired glucose tolerance. Diabetologia 2007. [CrossRef]

207. Grandner, M.A.; Schopfer, E.A.; Sands-Lincoln, M.; Jackson, N.; Malhotra, A. Relationship between sleep duration and body mass index depends on age. Obesity 2015. [CrossRef] [PubMed]

208. Levine, J.A.; Eberhardt, N.L.; Jensen, M.D. Role of nonexercise activity thermogenesis in resistance to fat gain in humans. Science 1999. [CrossRef] [PubMed]

209. Cirelli, C.; Gutierrez, C.M.; Tononi, G. Extensive and Divergent Effects of Sleep and Wakefulness on Brain Gene Expression. Neuron 2004. [CrossRef]

210. Kroeger, D.; Absi, G.; Gagliardi, C.; Bandaru, S.S.; Madara, J.C.; Ferrari, L.L.; Arrigoni, E.; Münzberg, H.; Scammell, T.E.; Saper, C.B.; et al. Galanin neurons in the ventrolateral preoptic area promote sleep and heat loss in mice. Nat. Commun. 2018, 9, 4129. [CrossRef]

211. Tasali, E.; Leproult, R.; Ehrmann, D.A.; Van Cauter, E. Slow-wave sleep and the risk of type 2 diabetes in humans. Proc. Natl. Acad. Sci. USA 2008. [CrossRef]

212. Isobe, Y.; Nishino, H. Signal transmission from the suprachiasmatic nucleus to the pineal gland via the paraventricular nucleus: Analysed from arg-vasopressin peptide, rPer2 mRNA and AVP mRNA changes and pineal AA-NAT mRNA after the melatonin injection during light and dark per. Brain Res. 2004. [CrossRef] 
213. Saper, C.B.; Cano, G.; Scammell, T.E. Homeostatic, circadian, and emotional regulation of sleep. J. Comp. Neurol. 2005, 493, 92-98. [CrossRef]

214. Adamantidis, A.; de Lecea, L. Sleep and metabolism: Shared circuits, new connections. Trends Endocrinol. Metab. 2008, 19, 362-370. [CrossRef] [PubMed]

215. Funato, H.; Tsai, A.L.; Willie, J.T.; Kisanuki, Y.; Williams, S.C.; Sakurai, T.; Yanagisawa, M. Enhanced Orexin Receptor-2 Signaling Prevents Diet-Induced Obesity and Improves Leptin Sensitivity. Cell Metab. 2009. [CrossRef]

216. Gonzàlez, J.A.; Reimann, F.; Burdakov, D. Dissociation between sensing and metabolism of glucose in sugar sensing neurones. J. Physiol. 2009, 587, 41-48. [CrossRef] [PubMed]

217. Borniger, J.C.; Walker, W.H.; sURBHI; Emmer, K.M.; Zhang, N.; Zalenski, A.A.; Muscarella, S.L.; Fitzgerald, J.A.; Smith, A.N.; Braam, C.J.; et al. A Role for Hypocretin/Orexin in Metabolic and Sleep Abnormalities in a Mouse Model of Non-metastatic Breast Cancer. Cell Metab. 2018, 28, 118-129.e5. [CrossRef]

218. Alam, M.A.; Kumar, S.; McGinty, D.; Alam, M.N.; Szymusiak, R. Neuronal activity in the preoptic hypothalamus during sleep deprivation and recovery sleep. J. Neurophysiol. 2014. [CrossRef]

219. Varin, C.; Rancillac, A.; Geoffroy, H.; Arthaud, S.; Fort, P.; Gallopin, T. Glucose induces slow-wave sleep by exciting the sleeppromoting neurons in the ventrolateral preoptic nucleus: A new link between sleep and metabolism. J. Neurosci. 2015, 35, 9900-9911. [CrossRef]

220. Chou, T.C.; Bjorkum, A.A.; Gaus, S.E.; Lu, J.; Scammell, T.E.; Saper, C.B. Afferents to the ventrolateral preoptic nucleus. J. Neurosci. 2002. [CrossRef]

221. Miyamoto, H.; Nakamaru-Ogiso, E.; Hamada, K.; Hensch, T.K. Serotonergic integration of circadian clock and ultradian sleep-wake cycles. J. Neurosci. 2012, 32, 14794-14803. [CrossRef]

222. Saper, C.B.; Fuller, P.M.; Pedersen, N.P.; Lu, J.; Scammell, T.E. Sleep State Switching. Neuron 2010, 68, 1023-1042. [CrossRef] [PubMed]

223. Minokoshi, Y.; Kim, Y.B.; Peroni, O.D.; Fryer, L.G.D.; Müller, C.; Carling, D.; Kahn, B.B. Leptin stimulates fatty-acid oxidation by activating AMP-activated protein kinase. Nature 2002, 415, 339-343. [CrossRef] [PubMed]

224. Kahn, B.B.; Flier, J.S. Obesity and insulin resistance. J. Clin. Investig. 2000, 106, 473-481. [CrossRef] [PubMed]

225. Huo, L.; Gamber, K.; Greeley, S.; Silva, J.; Huntoon, N.; Leng, X.H.; Bjørbæk, C. Leptin-Dependent Control of Glucose Balance and Locomotor Activity by POMC Neurons. Cell Metab. 2009, 9, 537-547. [CrossRef]

226. Kettner, N.M.; Mayo, S.A.; Hua, J.; Lee, C.; Moore, D.D.; Fu, L. Circadian dysfunction induces leptin resistance in mice. Cell Metab. 2015, 22, 448-459. [CrossRef]

227. Paschos, G.K.; Ibrahim, S.; Song, W.L.; Kunieda, T.; Grant, G.; Reyes, T.M.; Bradfield, C.A.; Vaughan, C.H.; Eiden, M.; Masoodi, M.; et al. Obesity in mice with adipocyte-specific deletion of clock component Arntl. Nat. Med. 2012. [CrossRef]

228. Jimeno, B.; Hau, M.; Verhulst, S. Corticosterone levels reflect variation in metabolic rate, independent of 'stress'. Sci. Rep. 2018, 8, 1-8. [CrossRef]

229. Leon-Mercado, L.; Chao, D.H.M.; del Carmen Basualdo, M.; Kawata, M.; Escobar, C.; Buijs, R.M. The arcuate nucleus: A site of fast negative feedback for corticosterone secretion in male rats. eNeuro 2017, 4, 1-14. [CrossRef]

230. Cavagnini, F.; Croci, M.; Putignano, P.; Petroni, M.L.; Invitti, C. Glucocorticoids and neuroendocrine function. Int. J. Obes. 2000. [CrossRef] [PubMed]

231. Kuperman, Y.; Weiss, M.; Dine, J.; Staikin, K.; Golani, O.; Ramot, A.; Nahum, T.; Kühne, C.; Shemesh, Y.; Wurst, W.; et al. CRFR1 in AgRP Neurons Modulates Sympathetic Nervous System Activity to Adapt to Cold Stress and Fasting. Cell Metab. 2016, 23, 1185-1199. [CrossRef] [PubMed]

232. Sefton, C.; Harno, E.; Davies, A.; Small, H.; Allen, T.J.; Wray, J.R.; Lawrence, C.B.; Coll, A.P.; White, A. Elevated hypothalamic glucocorticoid levels are associated with obesity and hyperphagia in male mice. Endocrinology 2016, 157, 4257-4265. [CrossRef] [PubMed]

233. Kas, M.J.H.; Bruijnzeel, A.W.; Haanstra, J.R.; Wiegant, V.M.; Adan, R.A.H. Differential regulation of agouti-related protein and neuropeptide $\mathrm{Y}$ in hypothalamic neurons following a stressful event. J. Mol. Endocrinol. 2005. [CrossRef]

234. Dimitrov, E.L.; DeJoseph, M.R.; Brownfield, M.S.; Urban, J.H. Involvement of neuropeptide Y Y1 receptors in the regulation of neuroendocrine corticotropin-releasing hormone neuronal activity. Endocrinology 2007, 148, 3666-3673. [CrossRef]

235. Stanley, B.G.; Leibowitz, S.F. Neuropeptide Y injected in the paraventricular hypothalamus: A powerful stimulant of feeding behavior. Proc. Natl. Acad. Sci. USA 1985. [CrossRef] [PubMed]

236. Erion, R.; King, A.N.; Wu, G.; Hogenesch, J.B.; Sehgal, A. Neural clocks and neuropeptide F/Y regulate circadian gene expression in a peripheral metabolic tissue. Elife 2016, 5, 1-21. [CrossRef]

237. Borjigin, J.; Samantha Zhang, L.; Calinescu, A.A. Circadian regulation of pineal gland rhythmicity. Mol. Cell. Endocrinol. 2012, 349, 13-19. [CrossRef]

238. Forrestel, A.C.; Miedlich, S.U.; Yurcheshen, M.; Wittlin, S.D.; Sellix, M.T. Chronomedicine and type 2 diabetes: Shining some light on melatonin. Diabetologia 2017, 60, 808-822. [CrossRef] [PubMed]

239. La Fleur, S.E.; Kalsbeek, A.; Wortel, J.; Van Der Vliet, J.; Buijs, R.M. Role for the pineal and melatonin in glucose homeostasis: Pinealectomy increases night- time glucose concentrations. J. Neuroendocrinol. 2001. [CrossRef] [PubMed] 
240. Kalsbeek, A.; La Fleur, S.; Van Heijningen, C.; Buijs, R.M. Suprachiasmatic GABAergic inputs to the paraventricular nucleus control plasma glucose concentrations in the rat via sympathetic innervation of the liver. J. Neurosci. 2004, 24, 7604-7613. [CrossRef]

241. Gamble, K.L.; Allen, G.C.; Zhou, T.; McMahon, D.G. Gastrin-releasing peptide mediates light-like resetting of the suprachiasmatic nucleus circadian pacemaker through cAMP response element-binding protein and Per1 activation. J. Neurosci. 2007, 27, 12078-12087. [CrossRef]

242. Alvarez, Y.; Glotfelty, L.G.; Blank, N.; Dohnalová, L.; Thaiss, C.A. The Microbiome as a Circadian Coordinator of Metabolism. Endocrinology 2020, 161, 1-9. [CrossRef] [PubMed]

243. Thaiss, C.A.; Levy, M.; Korem, T.; Dohnalová, L.; Shapiro, H.; Jaitin, D.A.; David, E.; Winter, D.R.; Gury-BenAri, M.; Tatirovsky, E.; et al. Microbiota Diurnal Rhythmicity Programs Host Transcriptome Oscillations. Cell 2016. [CrossRef]

244. Thaiss, C.A.; Zeevi, D.; Levy, M.; Zilberman-Schapira, G.; Suez, J.; Tengeler, A.C.; Abramson, L.; Katz, M.N.; Korem, T.; Zmora, N.; et al. Transkingdom control of microbiota diurnal oscillations promotes metabolic homeostasis. Cell 2014. [CrossRef]

245. Leone, V.; Gibbons, S.M.; Martinez, K.; Hutchison, A.L.; Huang, E.Y.; Cham, C.M.; Pierre, J.F.; Heneghan, A.F.; Nadimpalli, A.; Hubert, N.; et al. Effects of diurnal variation of gut microbes and high-fat feeding on host circadian clock function and metabolism. Cell Host Microbe 2015. [CrossRef]

246. Liang, X.; Bushman, F.D.; FitzGerald, G.A. Rhythmicity of the intestinal microbiota is regulated by gender and the host circadian clock. Proc. Natl. Acad. Sci. USA 2015. [CrossRef]

247. Turek, F.W.; Joshu, C.; Kohsaka, A.; Lin, E.; Ivanova, G.; McDearmon, E.; Laposky, A.; Losee-Olson, S.; Easton, A.; Jensen, D.R.; et al. Obesity and metabolic syndrome in circadian Clock mutant nice. Science 2005, 308, 1043-1045. [CrossRef] [PubMed]

248. Yang, S.; Liu, A.; Weidenhammer, A.; Cooksey, R.C.; McClain, D.; Kim, M.K.; Aguilera, G.; Abel, E.D.; Chung, J.H. The role of mPer2 clock gene in glucocorticoid and feeding rhythms. Endocrinology 2009. [CrossRef] [PubMed]

249. Patel, S.R.; Hu, F.B. Short sleep duration and weight gain: A systematic review. Obesity 2008, 16, 643-653. [CrossRef] [PubMed]

250. Bo, S.; Ciccone, G.; Durazzo, M.; Ghinamo, L.; Villois, P.; Canil, S.; Gambino, R.; Cassader, M.; Gentile, L.; Cavallo-Perin, P. Contributors to the obesity and hyperglycemia epidemics. A prospective study in a population-based cohort. Int. J. Obes. 2011. [CrossRef]

251. Shan, Z.; Li, Y.; Zong, G.; Guo, Y.; Li, J.; Manson, J.E.; Hu, F.B.; Willett, W.C.; Schernhammer, E.S.; Bhupathiraju, S.N. Rotating night shift work and adherence to unhealthy lifestyle in predicting risk of type 2 diabetes: Results from two large US cohorts of female nurses. BMJ 2018. [CrossRef] [PubMed]

252. Åkerstedt, T. Shift work and disturbed sleep/wakefulness. Occup. Med. 2003, 53, 89-94. [CrossRef] [PubMed]

253. Crispim, C.A.; Waterhouse, J.; Dâmaso, A.R.; Zimberg, I.Z.; Padilha, H.G.; Oyama, L.M.; Tufik, S.; De Mello, M.T. Hormonal appetite control is altered by shift work: A preliminary study. Metabolism 2011. [CrossRef]

254. Scheer, F.A.J.L.; Hilton, M.F.; Mantzoros, C.S.; Shea, S.A. Adverse metabolic and cardiovascular consequences of circadian misalignment. Proc. Natl. Acad. Sci. USA 2009. [CrossRef]

255. Sack, R.L.; Auckley, D.; Auger, R.R.; Carskadon, M.A.; Wright, K.P.; Vitiello, M.V.; Zhdanova, I.V. Circadian rhythm sleep disorders: Part I, basic principles, shift work and jet lag disorders. An American Academy of Sleep Medicine review. Sleep 2007, 30, 1460-1483. [CrossRef] [PubMed]

256. Markwald, R.R.; Melanson, E.L.; Smith, M.R.; Higgins, J.; Perreault, L.; Eckel, R.H.; Wright, K.P. Impact of insufficient sleep on total daily energy expenditure, food intake, and weight gain. Proc. Natl. Acad. Sci. USA 2013. [CrossRef] [PubMed]

257. Hatori, M.; Vollmers, C.; Zarrinpar, A.; Ditacchio, L.; Bushong, E.A.; Gill, S.; Leblanc, M.; Chaix, A.; Joens, M.; Fitzpatrick, J.A.J.; et al. Article Time-Restricted Feeding without Reducing Caloric Intake Prevents Metabolic Diseases in Mice Fed a High-Fat Diet. Cell Metab. 2012. [CrossRef]

258. Kurose, T.; Ueta, Y.; Yamamoto, Y.; Serino, R.; Ozaki, Y.; Saito, J.; Nagata, S.; Yamashita, H. Effects of restricted feeding on the activity of hypothalamic Orexin (OX)-A containing neurons and OX2 receptor mRNA level in the paraventricular nucleus of rats. Regul. Pept. 2002, 104, 145-151. [CrossRef]

259. Sundaram, S.; Yan, L. Time-restricted feeding reduces adiposity in mice fed a high-fat diet. Nutr. Res. 2016, 36, 603-611. [CrossRef] [PubMed]

260. Yasumoto, Y.; Hashimoto, C.; Nakao, R.; Yamazaki, H.; Hiroyama, H.; Nemoto, T.; Yamamoto, S.; Sakurai, M.; Oike, H.; Wada, N.; et al. Short-term feeding at the wrong time is sufficient to desynchronize peripheral clocks and induce obesity with hyperphagia, physical inactivity and metabolic disorders in mice. Metabolism 2016. [CrossRef]

261. Christie, S.; Vincent, A.D.; Li, H.; Frisby, C.L.; Kentish, S.J.; O'rielly, R.; Wittert, G.A.; Page, A.J. A rotating light cycle promotes weight gain and hepatic lipid storage in mice. Am. J. Physiol. Gastrointest. Liver Physiol. 2018. [CrossRef]

262. Shimizu, H.; Hanzawa, F.; Kim, D.; Sun, S.; Laurent, T.; Umeki, M.; Ikeda, S.; Mochizuki, S.; Oda, H. Delayed first active-phase meal, a breakfastskipping model, led to increased body weight and shifted the circadian oscillation of the hepatic clock and lipid metabolism-related genes in rats fed a high-fat diet. PLoS ONE 2018. [CrossRef]

263. Chaix, A.; Zarrinpar, A.; Miu, P.; Panda, S. Time-restricted feeding is a preventative and therapeutic intervention against diverse nutritional challenges. Cell Metab. 2014. [CrossRef]

264. Chaix, A.; Lin, T.; Le, H.D.; Chang, M.W.; Panda, S. Time-Restricted Feeding Prevents Obesity and Metabolic Syndrome in Mice Lacking a Circadian Clock. Cell Metab. 2019, 29, 303-319. [CrossRef] [PubMed] 
265. Olsen, M.K.; Choi, M.H.; Kulseng, B.; Zhao, C.M.; Chen, D. Time-restricted feeding on weekdays restricts weight gain: A study using rat models of high-fat diet-induced obesity. Physiol. Behav. 2017. [CrossRef] [PubMed]

266. Lo, M.T.; Chiang, W.Y.; Hsieh, W.H.; Escobar, C.; Buijs, R.M.; Hu, K. Interactive effects of dorsomedial hypothalamic nucleus and time-restricted feeding on fractal motor activity regulation. Front. Physiol. 2016. [CrossRef]

267. Boucsein, A.; Rizwan, M.Z.; Tups, A. Hypothalamic leptin sensitivity and health benefits of time-restricted feeding are dependent on the time of day in male mice. FASEB J. 2019, 33, 12175-12187. [CrossRef] [PubMed]

268. Sorrell, J.; Yates, E.; Rivir, M.; Woods, S.C.; Hogenesch, J.B.; Perez-Tilve, D. The central melanocortin system mediates the benefits of time-restricted feeding on energy balance. Physiol. Behav. 2020, 227, 113132. [CrossRef] [PubMed]

269. Dyar, K.A.; Lutter, D.; Artati, A.; Ceglia, N.J.; Liu, Y.; Armenta, D.; Jastroch, M.; Schneider, S.; de Mateo, S.; Cervantes, M.; et al. Atlas of Circadian Metabolism Reveals System-wide Coordination and Communication between Clocks. Cell 2018, 174, 1571-1585.e11. [CrossRef] [PubMed]

270. Eckel-Mahan, K.L.; Patel, V.R.; De Mateo, S.; Orozco-Solis, R.; Ceglia, N.J.; Sahar, S.; Dilag-Penilla, S.A.; Dyar, K.A.; Baldi, P.; Sassone-Corsi, P. Reprogramming of the circadian clock by nutritional challenge. Cell 2013, 155, 1464-1478. [CrossRef]

271. Clemenzi, M.N.; Martchenko, A.; Loganathan, N.; Tse, E.K.; Brubaker, P.L.; Belsham, D.D. Analysis of Western diet, palmitate and BMAL1 regulation of neuropeptide Y expression in the murine hypothalamus and BMAL1 knockout cell models. Mol. Cell. Endocrinol. 2020, 507, 110773. [CrossRef] [PubMed]

272. Tran, A.; He, W.; Jiang, N.; Chen, J.T.C.; Belsham, D.D. NAMPT and BMAL1 Are Independently Involved in the PalmitateMediated Induction of Neuroinflammation in Hypothalamic Neurons. Front. Endocrinol. 2020, 11, 1-10. [CrossRef]

273. Zhu, C.; Xu, Y.; Jiang, Z.; Tian, J.B.; Cassidy, R.M.; Cai, Z.; Shu, G.; Xu, Y.; Xue, M.; Arenkiel, B.R.; et al. Disrupted hypothalamic CRH neuron responsiveness contributes to diet-induced obesity. EMBO Rep. 2020, 1-14. [CrossRef]

274. Mazzone, C.M.; Liang-Guallpa, J.; Li, C.; Wolcott, N.S.; Boone, M.H.; Southern, M.; Kobzar, N.P.; de Araujo Salgado, I.; Reddy, D.M.; Sun, F.; et al. High-fat food biases hypothalamic and mesolimbic expression of consummatory drives. Nat. Neurosci. 2020, 23, 1253-1266. [CrossRef]

275. Morrison, S.F.; Madden, C.J.; Tupone, D. Central neural regulation of brown adipose tissue thermogenesis and energy expenditure. Cell Metab. 2014, 19, 741-756. [CrossRef] [PubMed]

276. Okamoto, S.; Sato, T.; Tateyama, M.; Kageyama, H.; Maejima, Y.; Nakata, M.; Hirako, S.; Matsuo, T.; Kyaw, S.; Shiuchi, T.; et al. Activation of AMPK-Regulated CRH Neurons in the PVH is Sufficient and Necessary to Induce Dietary Preference for Carbohydrate over Fat. Cell Rep. 2018. [CrossRef] [PubMed]

277. Qian, J.; Morris, C.J.; Caputo, R.; Wang, W.; Garaulet, M.; Scheer, F.A.J.L. Sex differences in the circadian misalignment effects on energy regulation. Proc. Natl. Acad. Sci. USA 2019, 116, 23806-23812. [CrossRef]

278. Cespedes Feliciano, E.M.; Rifas-Shiman, S.L.; Quante, M.; Redline, S.; Oken, E.; Taveras, E.M. Chronotype, Social Jet Lag, and Cardiometabolic Risk Factors in Early Adolescence. JAMA Pediatr. 2019. [CrossRef]

279. Leng, Y.; Blackwell, T.; Cawthon, P.M.; Ancoli-Israel, S.; Stone, K.L.; Yaffe, K. Association of Circadian Abnormalities in Older Adults with an Increased Risk of Developing Parkinson Disease. JAMA Neurol. 2020. [CrossRef] [PubMed]

280. Martinez-Nicolas, A.; Madrid, J.A.; García, F.J.; Campos, M.; Moreno-Casbas, M.T.; Almaida-Pagán, P.F.; Lucas-Sánchez, A.; Rol, M.A. Circadian monitoring as an aging predictor. Sci. Rep. 2018. [CrossRef]

281. Bellanti, F.; Iannelli, G.; Blonda, M.; Tamborra, R.; Villani, R.; Romano, A.; Calcagnini, S.; Mazzoccoli, G.; Vinciguerra, M.; Gaetani, S.; et al. Alterations of Clock Gene RNA Expression in Brain Regions of a Triple Transgenic Model of Alzheimer's Disease. J. Alzheimer's Dis. 2017, 59, 615-631. [CrossRef]

282. Nordengen, K.; Kirsebom, B.E.; Henjum, K.; Selnes, P.; Gísladóttir, B.; Wettergreen, M.; Torsetnes, S.B.; Grøntvedt, G.R.; Waterloo, K.K.; Aarsland, D.; et al. Glial activation and inflammation along the Alzheimer's disease continuum. J. Neuroinflamm. 2019, 16, 1-13. [CrossRef] [PubMed]

283. Garwood, C.J.; Pooler, A.M.; Atherton, J.; Hanger, D.P.; Noble, W. Astrocytes are important mediators of A $\beta$-induced neurotoxicity and tau phosphorylation in primary culture. Cell Death Dis. 2011. [CrossRef]

284. Fakhoury, M. Microglia and astrocytes in Alzheimer's disease: Implications for therapy. Curr. Neuropharmacol. 2017. [CrossRef]

285. Hayashi, Y.; Koyanagi, S.; Kusunose, N.; Okada, R.; Wu, Z.; Tozaki-Saitoh, H.; Ukai, K.; Kohsaka, S.; Inoue, K.; Ohdo, S.; et al. The intrinsic microglial molecular clock controls synaptic strength via the circadian expression of cathepsin S. Sci. Rep. 2013. [CrossRef] [PubMed]

286. Bojarskaite, L.; Bjørnstad, D.M.; Pettersen, K.H.; Cunen, C.; Hermansen, G.H.; Åbjørsbråten, K.S.; Chambers, A.R.; Sprengel, R.; Vervaeke, K.; Tang, W.; et al. Astrocytic Ca2+ signaling is reduced during sleep and is involved in the regulation of slow wave sleep. Nat. Commun. 2020. [CrossRef]

287. Hayashi, Y. Diurnal Spatial Rearrangement of Microglial Processes through the Rhythmic Expression of P2Y12 Receptors. J. Neurol. Disord. 2013. [CrossRef]

288. Ni, J.; Wu, Z.; Meng, J.; Saito, T.; Saido, T.C.; Qing, H.; Nakanishi, H. An impaired intrinsic microglial clock system induces neuroinflammatory alterations in the early stage of amyloid precursor protein knock-in mouse brain. J. Neuroinflamm. 2019, 16, 1-15. [CrossRef] [PubMed]

289. Fonken, L.K.; Kitt, M.M.; Gaudet, A.D.; Barrientos, R.M.; Watkins, L.R.; Maier, S.F. Diminished circadian rhythms in hippocampal microglia may contribute to age-related neuroinflammatory sensitization. Neurobiol. Aging 2016. [CrossRef] [PubMed] 
290. Pan, J.; Ma, N.; Yu, B.; Zhang, W.; Wan, J. Transcriptomic profiling of microglia and astrocytes throughout aging. J. Neuroinflamm. 2020, 17, 1-19. [CrossRef] [PubMed]

291. Harper, D.G.; Stopa, E.G.; Kuo-Leblanc, V.; McKee, A.C.; Asayama, K.; Volicer, L.; Kowall, N.; Satlin, A. Dorsomedial SCN neuronal subpopulations subserve different functions in human dementia. Brain 2008, 131, 1609-1617. [CrossRef]

292. Baloyannis, S.J.; Mavroudis, I.; Mitilineos, D.; Baloyannis, I.S.; Costa, V.G. The Hypothalamus in Alzheimer's Disease: A Golgi and Electron Microscope Study. Am. J. Alzheimer's Dis. Other Demen. 2015, 30, 478-487. [CrossRef]

293. Swaab, D.F.; Fliers, E.; Partiman, T.S. The suprachiasmatic nucleus of the human brain in relation to sex, age and senile dementia. Brain Res. 1985. [CrossRef]

294. McDuff, T.; Sumi, S.M. Subcortical degeneration in Alzheimer's disease. Neurology 1985, 35, 123. [CrossRef]

295. Storandt, M.; Kaskie, B.; Von Dras, D.D. Temporal memory for remote events in healthy aging and dementia. Psychol. Aging 1998. [CrossRef]

296. Carroll, J.C.; Iba, M.; Bangasser, D.A.; Valentino, R.J.; James, M.J.; Brunden, K.R.; Lee, V.M.Y.; Trojanowski, J.Q. Chronic stress exacerbates tau pathology, neurodegeneration, and cognitive performance through a corticotropin-releasing factor receptordependent mechanism in a transgenic mouse model of tauopathy. J. Neurosci. 2011. [CrossRef]

297. Song, H.; Moon, M.; Choe, H.K.; Han, D.H.; Jang, C.; Kim, A.; Cho, S.; Kim, K.; Mook-Jung, I. A $\beta$-induced degradation of BMAL1 and CBP leads to circadian rhythm disruption in Alzheimer's disease. Mol. Neurodegener. 2015, 10, 1-15. [CrossRef]

298. Kress, G.J.; Liao, F.; Dimitry, J.; Cedeno, M.R.; FitzGerald, G.A.; Holtzman, D.M.; Musiek, E.S. Regulation of amyloid- $\beta$ dynamics and pathology by the circadian clock. J. Exp. Med. 2018, 215, 1059-1068. [CrossRef] [PubMed]

299. Kang, J.E.; Lim, M.M.; Bateman, R.J.; Lee, J.J.; Smyth, L.P.; Cirrito, J.R.; Fujiki, N.; Nishino, S.; Holtzman, D.M. Amyloid- $\beta$ dynamics are regulated by orexin and the sleep-wake cycle. Science 2009. [CrossRef]

300. Musiek, E.S.; Bhimasani, M.; Zangrilli, M.A.; Morris, J.C.; Holtzman, D.M.; Ju, Y.E.S. Circadian rest-activity pattern changes in aging and preclinical Alzheimer disease. JAMA Neurol. 2018. [CrossRef]

301. Cronin, P.; McCarthy, M.J.; Lim, A.S.P.; Salmon, D.P.; Galasko, D.; Masliah, E.; De Jager, P.L.; Bennett, D.A.; Desplats, P. Circadian alterations during early stages of Alzheimer's disease are associated with aberrant cycles of DNA methylation in BMAL1. Alzheimer's Dement. 2017. [CrossRef]

302. Khachiyants, N.; Trinkle, D.; Son, S.J.; Kim, K.Y. Sundown syndrome in persons with dementia: An update. Psychiatry Investig. 2011. [CrossRef]

303. Canevelli, M.; Valletta, M.; Trebbastoni, A.; Sarli, G.; D’Antonio, F.; Tariciotti, L.; de Lena, C.; Bruno, G. Sundowning in Dementia: Clinical relevance, pathophysiological determinants, and therapeutic approaches. Front. Med. 2016, 3, 73. [CrossRef]

304. Cohen-Mansfield, J.; Garfinkel, D.; Lipson, S. Melatonin for treatment of sundowning in elderly persons with dementia-A preliminary study. Arch. Gerontol. Geriatr. 2000, 31, 65-76. [CrossRef]

305. Klaffke, S.; Staedt, J. Sundowing and circadian rhythm disorders in dementia. Acta Neurol. Belg. 2006, $106,168$.

306. Yao, Y.; Zhang, W.; Ming, R.; Deng, Q.; Zuo, A.; Zhang, S.; Ying, Y.; Zhao, Y.; Ma, J. Noninvasive 40-Hz Light Flicker Rescues Circadian Behavior and Abnormal Lipid Metabolism Induced by Acute Ethanol Exposure via Improving SIRT1 and the Circadian Clock in the Liver-Brain Axis. Front. Pharmacol. 2020. [CrossRef] [PubMed]

307. Sevilla, D.A.; Rodríguez, M.T.C.; Rodríguez, P.H.; Sánchez, M.F.; Mora, J.A.V.; Gago-Veiga, A.B. Is There a Characteristic Clinical Profile for Patients with Dementia and Sundown Syndrome? J. Alzheimer's Dis. 2018. [CrossRef]

308. Todd, W.D.; Fenselau, H.; Wang, J.L.; Zhang, R.; Machado, N.L.; Venner, A.; Broadhurst, R.Y.; Kaur, S.; Lynagh, T.; Olson, D.P.; et al. A hypothalamic circuit for the circadian control of aggression. Nat. Neurosci. 2018, 21, 717-724. [CrossRef] [PubMed]

309. Todd, W.D. Potential Pathways for Circadian Dysfunction and Sundowning-Related Behavioral Aggression in Alzheimer's Disease and Related Dementias. Front. Neurosci. 2020, 14, 1-14. [CrossRef]

310. Kunwar, P.S.; Zelikowsky, M.; Remedios, R.; Cai, H.; Yilmaz, M.; Meister, M.; Anderson, D.J. Ventromedial hypothalamic neurons control a defensive emotion state. Elife 2015. [CrossRef]

311. Rosenthal, N.E.; Sack, D.A.; Gillin, J.C.; Lewy, A.J.; Goodwin, F.K.; Davenport, Y.; Mueller, P.S.; Newsome, D.A.; Wehr, T.A. Seasonal Affective Disorder: A Description of the Syndrome and Preliminary Findings With Light Therapy. Arch. Gen. Psychiatry 1984. [CrossRef]

312. Lewy, A.J.; Lefler, B.J.; Emens, J.S.; Bauer, V.K. The circadian basis of winter depression. Proc. Natl. Acad. Sci. USA 2006, 103, 7414-7419. [CrossRef] [PubMed]

313. Terman, M.; Terman, J.S.; Quitkin, F.M.; McGrath, P.J.; Stewart, J.W.; Rafferty, B. Light therapy for Seasonal Affective Disorder. A review of efficacy. Neuropsychopharmacology 1989, 2, 1-22. [CrossRef]

314. Zhou, J.N.; Hofman, M.A.; Swaab, D.F. VIP neurons in the human SCN in relation to sex, age, and Alzheimer's disease. Neurobiol. Aging 1995, 16, 571-576. [CrossRef]

315. Roy, U.; Heredia-Muñoz, M.T.; Stute, L.; Höfling, C.; Matysik, J.; Meijer, J.H.; Roßner, S.; Alia, A. Degeneration of the Suprachiasmatic Nucleus in an Alzheimer's Disease Mouse Model Monitored by in vivo Magnetic Resonance Relaxation Measurements and Immunohistochemistry. J. Alzheimer's Dis. 2019, 69, 363-375. [CrossRef] [PubMed]

316. Nagare, R.; Possidente, B.; Lagalwar, S.; Figueiro, M.G. Robust light-dark patterns and reduced amyloid load in an Alzheimer's disease transgenic mouse model. Sci. Rep. 2020, 10, 1-8. [CrossRef] [PubMed]

317. Stief, A. über die anatomischen Grundlagen der vegetativen Störungen bei Geisteskrankheiten. Dtsch. Z. Nervenheilkd. 1927. [CrossRef] 
318. Csernansky, J.G.; Dong, H.; Fagan, A.M.; Wang, L.; Xiong, C.; Holtzman, D.M.; Morris, J.C. Plasma cortisol and progression of dementia in subjects with Alzheimer-type dementia. Am. J. Psychiatry 2006, 163, 2164-2169. [CrossRef] [PubMed]

319. Souza, E.B.D.; Whitehouse, P.J.; Price, D.L.; Vale, W.W. Abnormalities in Corticotropin-releasing Hormone (CRH) in Alzheimer's Disease and Other Human Disorders. Ann. N. Y. Acad. Sci. 1987, 512, 237-247. [CrossRef]

320. Gallone, S.; Boschi, S.; Rubino, E.; De Martino, P.; Scarpini, E.; Galimberti, D.; Fenoglio, C.; Acutis, P.L.; Maniaci, M.G.; Pinessi, L.; et al. Is HCRTR2 a genetic risk factor for Alzheimer's disease? Dement. Geriatr. Cogn. Disord. 2014. [CrossRef] [PubMed]

321. Schmidt, F.M.; Kratzsch, J.; Gertz, H.J.; Tittmann, M.; Jahn, I.; Pietsch, U.C.; Kaisers, U.X.; Thiery, J.; Hegerl, U.; Schönknecht, P. Cerebrospinal Fluid Melanin-Concentrating Hormone (MCH) and Hypocretin-1 (HCRT-1, Orexin-A) in Alzheimer's Disease. PLoS ONE 2013, 8, e63136. [CrossRef]

322. Liguori, C.; Romigi, A.; Nuccetelli, M.; Zannino, S.; Sancesario, G.; Martorana, A.; Albanese, M.; Mercuri, N.B.; Izzi, F.; Bernardini, S.; et al. Orexinergic system dysregulation, sleep impairment, and cognitive decline in Alzheimer disease. JAMA Neurol. 2014, 71, 1498-1505. [CrossRef] [PubMed]

323. Haller, J. The neurobiology of abnormal manifestations of aggression-A review of hypothalamic mechanisms in cats, rodents, and humans. Brain Res. Bull. 2013. [CrossRef]

324. Venturelli, M.; Sollima, A.; Cè, E.; Limonta, E.; Bisconti, A.V.; Brasioli, A.; Muti, E.; Esposito, F. Effectiveness of Exercise- and Cognitive-Based Treatments on Salivary Cortisol Levels and Sundowning Syndrome Symptoms in Patients with Alzheimer's Disease. J. Alzheimer's Dis. 2016. [CrossRef]

325. Liguori, I.; Russo, G.; Curcio, F.; Bulli, G.; Aran, L.; Della-Morte, D.; Gargiulo, G.; Testa, G.; Cacciatore, F.; Bonaduce, D.; et al. Oxidative stress, aging, and diseases. Clin. Interv. Aging 2018. [CrossRef] [PubMed]

326. Adidharma, W.; Deats, S.P.; Ikeno, T.; Lipton, J.W.; Lonstein, J.S.; Yan, L. Orexinergic modulation of serotonin neurons in the dorsal raphe of a diurnal rodent, Arvicanthis niloticus. Horm. Behav. 2019. [CrossRef] [PubMed]

327. Landgraf, D.; Long, J.E.; Proulx, C.D.; Barandas, R.; Malinow, R.; Welsh, D.K. Genetic Disruption of Circadian Rhythms in the Suprachiasmatic Nucleus Causes Helplessness, Behavioral Despair, and Anxiety-like Behavior in Mice. Biol. Psychiatry 2016, 80, 827-835. [CrossRef]

328. Tsuchimine, S.; Hattori, K.; Ota, M.; Hidese, S.; Teraishi, T.; Sasayama, D.; Hori, H.; Noda, T.; Yoshida, S.; Yoshida, F.; et al. Reduced plasma orexin-A levels in patients with bipolar disorder. Neuropsychiatr. Dis. Treat. 2019, 15, 2221-2230. [CrossRef]

329. Thorn, L.; Evans, P.; Cannon, A.; Hucklebridge, F.; Evans, P.; Clow, A. Seasonal differences in the diurnal pattern of cortisol secretion in healthy participants and those with self-assessed seasonal affective disorder. Psychoneuroendocrinology 2011. [CrossRef] [PubMed]

330. Majrashi, N.A.; Ahearn, T.S.; Waiter, G.D. Brainstem volume mediates seasonal variation in depressive symptoms: A cross sectional study in the UK Biobank cohort. Sci. Rep. 2020. [CrossRef] [PubMed]

331. Abulseoud, O.A.; Camsari, U.M.; Ruby, C.L.; Mohamed, K.; Abdel Gawad, N.M.; Kasasbeh, A.; Yüksel, M.Y.; Choi, D.S. Lateral hypothalamic kindling induces manic-like behavior in rats: A novel animal model. Int. J. Bipolar Disord. 2014. [CrossRef]

332. Watson, S.; Gallagher, P.; Ritchie, J.C.; Ferrier, I.N.; Young, A.H. Hypothalamic-pituitary-adrenal axis function in patients with bipolar disorder. Br. J. Psychiatry 2004, 184, 496-502. [CrossRef] [PubMed]

333. Fries, G.R.; Vasconcelos-Moreno, M.P.; Gubert, C.; Dos Santos, B.T.M.Q.; Sartori, J.; Eisele, B.; Ferrari, P.; Fijtman, A.; Rüegg, J.; Gassen, N.C.; et al. Hypothalamic-pituitary-adrenal axis dysfunction and illness progression in bipolar disorder. Int. J. Neuropsychopharmacol. 2015, 18, 1-10. [CrossRef]

334. van den Berg, M.T.; Wester, V.L.; Vreeker, A.; Koenders, M.A.; Boks, M.P.; van Rossum, E.F.C.; Spijker, A.T. Higher cortisol levels may proceed a manic episode and are related to disease severity in patients with bipolar disorder. Psychoneuroendocrinology 2020, 119. [CrossRef]

335. Manaye, K.F.; Lei, D.L.; Tizabi, Y.; Dávila-García, M.I.; Mouton, P.R.; Kelly, P.H. Selective neuron loss in the paraventricular nucleus of hypothalamus in patients suffering from major depression and bipolar disorder. J. Neuropathol. Exp. Neurol. 2005, 64, 224-229. [CrossRef] [PubMed]

336. Roybal, K.; Theobold, D.; Graham, A.; DiNieri, J.A.; Russo, S.J.; Krishnan, V.; Chakravarty, S.; Peevey, J.; Oehrlein, N.; Birnbaum, S.; et al. Mania-like behavior induced by disruption of CLOCK. Proc. Natl. Acad. Sci. USA 2007, 104, 6406-6411. [CrossRef]

337. Adam, C.L.; Moar, K.M.; Logie, T.J.; Ross, A.W.; Barrett, P.; Morgan, P.J.; Mercer, J.G. Photoperiod regulates growth, puberty and hypothalamic neuropeptide and receptor gene expression in female Siberian hamsters. Endocrinology 2000. [CrossRef] [PubMed]

338. Pail, G.; Huf, W.; Pjrek, E.; Winkler, D.; Willeit, M.; Praschak-Rieder, N.; Kasper, S. Bright-light therapy in the treatment of mood disorders. Neuropsychobiology 2011, 64, 152-162. [CrossRef]

339. Rosen, L.N.; Targum, S.D.; Terman, M.; Bryant, M.J.; Hoffman, H.; Kasper, S.F.; Hamovit, J.R.; Docherty, J.P.; Welch, B.; Rosenthal, N.E. Prevalence of seasonal affective disorder at four latitudes. Psychiatry Res. 1990, 31, 131-144. [CrossRef]

340. Vandewalle, G.; Hébert, M.; Beaulieu, C.; Richard, L.; Daneault, V.; Garon, M.L.; Leblanc, J.; Grandjean, D.; Maquet, P.; Schwartz, S.; et al. Abnormal hypothalamic response to light in seasonal affective disorder. Biol. Psychiatry 2011, 70, 954-961. [CrossRef]

341. Kräuchi, K.; Wirz-Justice, A. The four seasons: Food intake frequency in seasonal affective disorder in the course of a year. Psychiatry Res. 1988, 25, 323-338. [CrossRef]

342. Sandman, N.; Merikanto, I.; Määttänen, H.; Valli, K.; Kronholm, E.; Laatikainen, T.; Partonen, T.; Paunio, T. Winter is coming: Nightmares and sleep problems during seasonal affective disorder. J. Sleep Res. 2016. [CrossRef] 
343. Adidharma, W.; Leach, G.; Yan, L. Orexinergic signaling mediates light-induced neuronal activation in the dorsal raphe nucleus. Neuroscience 2012. [CrossRef]

344. Deats, S.P.; Adidharma, W.; Lonstein, J.S.; Yan, L. Attenuated orexinergic signaling underlies depression-like responses induced by daytime light deficiency. Neuroscience 2014, 272, 252-260. [CrossRef] [PubMed]

345. Mukherjee, S.; Coque, L.; Cao, J.L.; Kumar, J.; Chakravarty, S.; Asaithamby, A.; Graham, A.; Gordon, E.; Enwright, J.F.; Dileone, R.J.; et al. Knockdown of clock in the ventral tegmental area through RNA interference results in a mixed state of mania and depression-like behavior. Biol. Psychiatry 2010. [CrossRef]

346. Brami-Cherrier, K.; Lewis, R.G.; Cervantes, M.; Liu, Y.; Tognini, P.; Baldi, P.; Sassone-Corsi, P.; Borrelli, E. Cocaine-mediated circadian reprogramming in the striatum through dopamine D2R and PPAR $\gamma$ activation. Nat. Commun. 2020, 11, 4448. [CrossRef] [PubMed]

347. Seney, M.L.; Cahill, K.; Enwright, J.F.; Logan, R.W.; Huo, Z.; Zong, W.; Tseng, G.; McClung, C.A. Diurnal rhythms in gene expression in the prefrontal cortex in schizophrenia. Nat. Commun. 2019, 10,1-11. [CrossRef]

348. Tognin, S.; Rambaldelli, G.; Perlini, C.; Bellani, M.; Marinelli, V.; Zoccatelli, G.; Alessandrini, F.; Pizzini, F.B.; Beltramello, A.; Terlevic, R.; et al. Enlarged hypothalamic volumes in schizophrenia. Psychiatry Res. Neuroimaging 2012. [CrossRef] [PubMed]

349. Busch, J.R.; Jacobsen, C.; Lynnerup, N.; Banner, J.; Møller, M. Expression of vasopressin mRNA in the hypothalamus of individuals with a diagnosis of schizophrenia. Brain Behav. 2019. [CrossRef]

350. An, K.; Zhao, H.; Miao, Y.; Xu, Q.; Li, Y.F.; Ma, Y.Q.; Shi, Y.M.; Shen, J.W.; Meng, J.J.; Yao, Y.G.; et al. A circadian rhythm-gated subcortical pathway for nighttime-light-induced depressive-like behaviors in mice. Nat. Neurosci. 2020, 23, 869-880. [CrossRef]

351. Walker, W.H.; Walton, J.C.; DeVries, A.C.; Nelson, R.J. Circadian rhythm disruption and mental health. Transl. Psychiatry 2020, 10, 28. [CrossRef] [PubMed]

352. Kasahara, T.; Kubota, M.; Miyauchi, T.; Noda, Y.; Mouri, A.; Nabeshima, T.; Kato, T. Mice with neuron-specific accumulation of mitochondrial DNA mutations show mood disorder-like phenotypes. Mol. Psychiatry 2006. [CrossRef] [PubMed]

353. Logan, R.W.; Parekh, P.K.; Kaplan, G.N.; Becker-Krail, D.D.; Williams, W.P.; Yamaguchi, S.; Yoshino, J.; Shelton, M.A.; Zhu, X.; Zhang, H.; et al. NAD+ cellular redox and SIRT1 regulate the diurnal rhythms of tyrosine hydroxylase and conditioned cocaine reward. Mol. Psychiatry 2019. [CrossRef] [PubMed]

354. He, B.; Nohara, K.; Park, N.; Park, Y.S.; Guillory, B.; Zhao, Z.; Garcia, J.M.; Koike, N.; Lee, C.C.; Takahashi, J.S.; et al. The Small Molecule Nobiletin Targets the Molecular Oscillator to Enhance Circadian Rhythms and Protect against Metabolic Syndrome. Cell Metab. 2016, 23, 610-621. [CrossRef]

355. Nohara, K.; Mallampalli, V.; Nemkov, T.; Wirianto, M.; Yang, J.; Ye, Y.; Sun, Y.; Han, L.; Esser, K.A.; Mileykovskaya, E.; et al. Nobiletin fortifies mitochondrial respiration in skeletal muscle to promote healthy aging against metabolic challenge. Nat. Commun. 2019, 10, 3923. [CrossRef]

356. Burke, A.C.; Sutherland, B.G.; Telford, D.E.; Morrow, M.R.; Sawyez, C.G.; Edwards, J.Y.; Drangova, M.; Huff, M.W. Intervention with citrus flavonoids reverses obesity and improves metabolic syndrome and atherosclerosis in obese Ldlr / mice. J. Lipid Res. 2018, 59, 1714-1728. [CrossRef]

357. Petrenko, V.; Gandasi, N.R.; Sage, D.; Tengholm, A.; Barg, S.; Dibner, C. In pancreatic islets from type 2 diabetes patients, the dampened circadian oscillators lead to reduced insulin and glucagon exocytosis. Proc. Natl. Acad. Sci. USA 2020, 117, 2484-2495. [CrossRef] [PubMed]

358. Rakshit, K.; Matveyenko, A.V. Induction of Core Circadian Clock Transcription Factor Bmal1 Enhances $\beta$ Cell Function and Protects Against Obesity-Induced Glucose Intolerance. Diabetes 2020. [CrossRef] [PubMed]

359. Nakamura, T.J.; Nakamura, W.; Yamazaki, S.; Kudo, T.; Cutler, T.; Colwell, C.S.; Block, G.D. Age-related decline in circadian output. J. Neurosci. 2011. [CrossRef] [PubMed]

360. Sato, S.; Solanas, G.; Peixoto, F.O.; Bee, L.; Symeonidi, A.; Schmidt, M.S.; Brenner, C.; Masri, S.; Benitah, S.A.; Sassone-Corsi, P. Circadian Reprogramming in the Liver Identifies Metabolic Pathways of Aging. Cell 2017, 170, 664-677.e11. [CrossRef]

361. Zwighaft, Z.; Aviram, R.; Shalev, M.; Rousso-Noori, L.; Kraut-Cohen, J.; Golik, M.; Brandis, A.; Reinke, H.; Aharoni, A.; Kahana, C.; et al. Circadian Clock Control by Polyamine Levels through a Mechanism that Declines with Age. Cell Metab. 2015, 22, 874-885. [CrossRef] [PubMed]

362. Hood, S.; Amir, S. The aging clock: Circadian rhythms and later life. J. Clin. Investig. 2017, 127, 437-446. [CrossRef] [PubMed]

363. Chang, H.C.; Guarente, L. XSIRT1 mediates central circadian control in the SCN by a mechanism that decays with aging. Cell 2013, 153, 1448. [CrossRef]

364. Levine, D.C.; Hong, H.; Weidemann, B.J.; Ramsey, K.M.; Affinati, A.H.; Schmidt, M.S.; Cedernaes, J.; Omura, C.; Braun, R.; Lee, C.; et al. NAD+ Controls Circadian Reprogramming through PER2 Nuclear Translocation to Counter Aging. Mol. Cell 2020. [CrossRef] 